\title{
Julgando sob incerteza: heurísticas e vieses e o ensino de probabilidade e estatística
}

\author{
Claudio Roberto de Oliveira
}

\author{
DISSERTAÇÃO APRESENTADA \\ $\mathrm{AO}$ \\ INSTITUTO DE MATEMÁTICA E ESTATÍSTICA \\ DA \\ UNIVERSIDADE DE SÃO PAULO \\ PARA \\ OBTENÇÃO DO TÍTULO \\ $\mathrm{DE}$ \\ MESTRE EM CIÊNCIAS
}

Programa: Mestrado Profissional em Ensino de Matemática

Orientadora: Profa. Dra. Lisbeth Kaiserlian Cordani 


\section{Julgando sob incerteza: heurísticas e vieses e o ensino de probabilidade e estatística}

Esta é a versão corrigida da dissertação elaborada pelo candidato Claudio Roberto de Oliveira, após a defesa perante a Comissão Julgadora. 


\section{AGRADECIMENTOS}

À minha família pelo apoio incondicional em todos esses anos de árduo e verdadeiro caminho.

À Lisbeth Cordani pela atenção e dedicação iluminadas, trazendo durante os anos de nossa convivência verdadeira ternura por trilhar o conhecimento não só da probabilidade e estatística que amamos, mas o amor em ensiná-las.

Aos professores do IMEUSP pela atenção e apoio durante o programa de Mestrado, bem como a todos aqueles que me orientaram e expandiram minha paixão pela Estatística durante os anos de aperfeiçoamento. 


\section{RESUMO}

OLIVEIRA, C. R. Julgando sob incerteza: heurísticas e vieses e o ensino de probabilidade e estatística. Dissertação (Mestrado) - Instituto de Matemática e Estatística, Universidade de São Paulo, 2016.

Ao encontrar o conteúdo de probabilidade e estatística no ensino médio no Brasil, o aluno se depara com uma abordagem matemática da teoria, fruto de uma tradição escolar onde a matemática sempre foi ensinada de forma determinística, fornecendo resultados e resoluções de problemas como se fossem exatos dentro de diversos contextos. É o que verificamos em um referencial dos livros didáticos utilizados pelos professores nas escolas, em que encontramos um destaque para uma abordagem permeada por formalismos e excessivas fórmulas com notações da teoria dos conjuntos, com pouca ou por vezes ausência total de discussões que permitam uma visão consistente da teoria referente às disciplinas de probabilidade e estatística. Diante de tal cenário, muitos vieses de raciocínio são encontrados e citados frequentemente em trabalhos voltados para a formação de professores com foco na educação estatística, como erros e dificuldades na concepção de conceitos de probabilidade e estatística. Vamos abordar o trabalho de alguns autores sobre o raciocínio humano no que se refere a erros, vieses e falácias em uma variedade de padrões mentais. Os padrões são identificados como heurísticas utilizadas pelas pessoas ao julgar sob incerteza, em que elas se apoiam em um número limitado de princípios que reduzem o trabalho complexo mental de fornecer probabilidade e predizer valores por simples julgamentos de forma sistemática. Utilizaremos estes próprios princípios heurísticos em uma sondagem destes possíveis modelos mentais para, em seguida, serem aplicadas na forma de ações em sala de aula. A finalidade é tentar ampliar o espectro do raciocínio do aluno para que ele tenha mais embasamento ao fazer estimativas e previsões em diferentes contextos. Finalmente, estas atividades foram testadas para verificarmos sua efetividade diante de modelos mentais que podem persistir, como apontam as referências, mesmo em estudantes e profissionais suficientemente treinados em estatística.

Palavras-chave: Ensino de Estatística, Heurísticas, Vieses, Falácias, Probabilidade. 


\begin{abstract}
OLIVEIRA, C. R. Judging under uncertainty: heuristics and biases and teaching of probability and statistics. Dissertação (Mestrado) - Institute of Mathematics and Statistics, University of São Paulo, in 2016.
\end{abstract}

To find the contents of probability and statistics in high school in Brazil, the student is faced with a mathematical approach to the theory, the result of a school tradition in which mathematics has always been taught in a deterministic way, providing results and troubleshooting as if they were accurate within different contexts. It is what we see in a reference textbooks used by teachers in schools, where we find a highlight for permeated approach formalities and excessive formulas with notations of set theory, with little or sometimes total lack of discussions to enable a consistent view theory related to the disciplines of probability and statistics. Faced with such a scenario, many reasoning biases are found and often cited in studies related to teacher education with a focus on statistics education, such as errors and difficulties in designing concepts of probability and statistics. We will address the work of some authors on human reasoning which concentrates errors, biases and fallacies in a variety of mental patterns. The patterns are identified as heuristics that people use in judging under uncertainty, where they rely on a limited number of principles that reduce complex mental work to provide probability and predict values for simple trials systematically. We will use these very principles heuristic in a survey of these possible mental models to then be applied, in a second step, actions in the classroom. The purpose is to try to broaden the spectrum of student reasoning so that it has more basis to make estimates and forecasts in different contexts. Finally, these activities were tested in order to verify its effectiveness before mental models that may persist, as shown by the references, even for students and sufficiently trained in statistical professionals.

Keywords: Statistics Teaching, Heuristics, Biases, Fallacies, Probability. 


\section{SUMÁRIO}

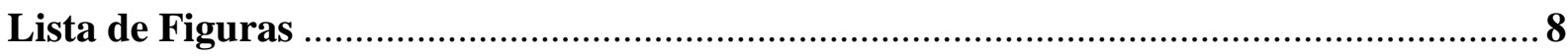

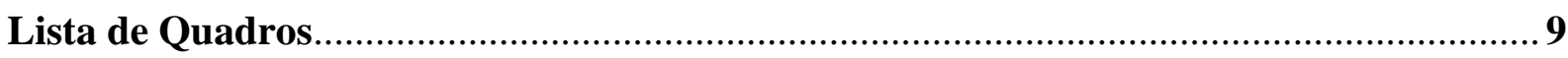

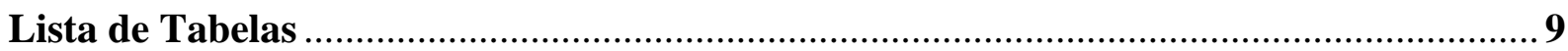

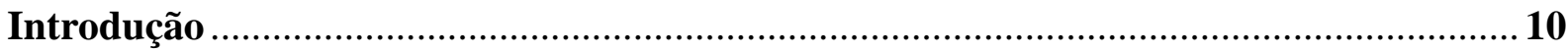

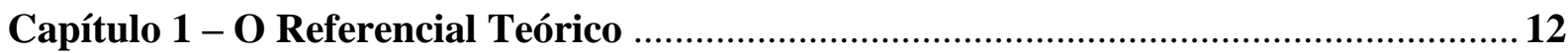

1.1 O ensino de Probabilidade e Estatística na Educação Básica.................................... 12

1.2 Erros e dificuldades no aprendizado de conceitos estatísticos ................................... 18

1.3 Raciocínio matemático versus raciocínio estatístico .............................................. 21

1.4 Julgando sob incerteza: O Programa Heurísticas e Vieses .......................................... 23

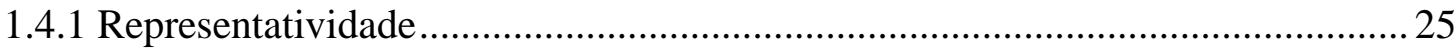

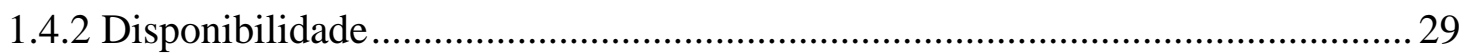

1.5 Crítica ao Programa Heurísticas e Vieses: A representação da informação.................. 30

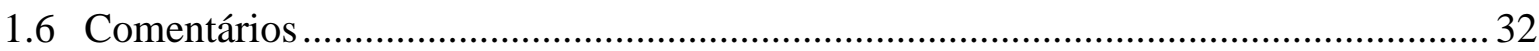

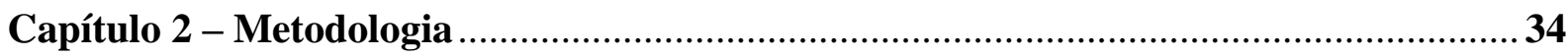

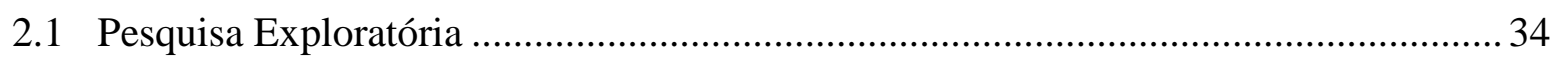

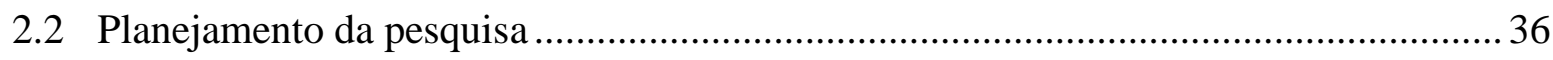

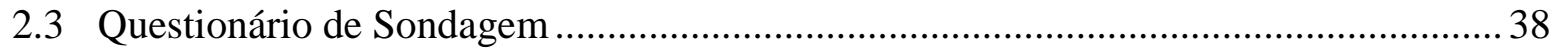

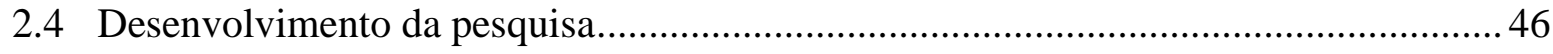

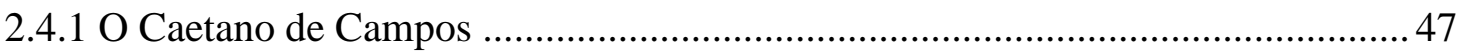

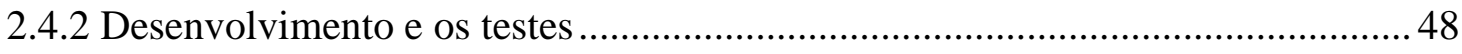

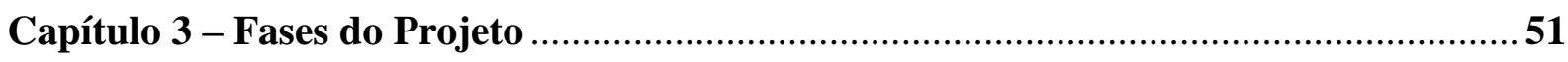

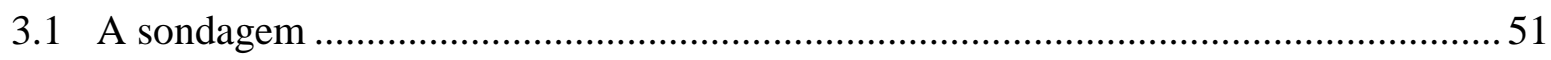

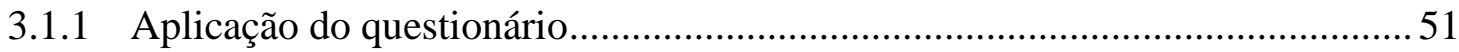

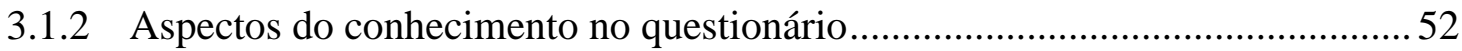

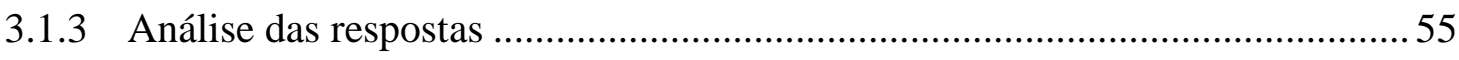

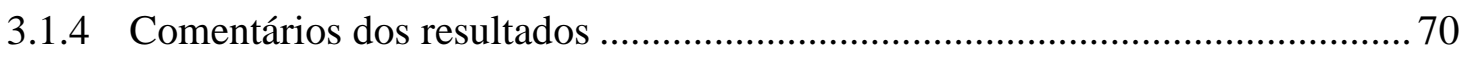

3.2 Ações didáticas e a experiência em sala de aula..................................................... 73

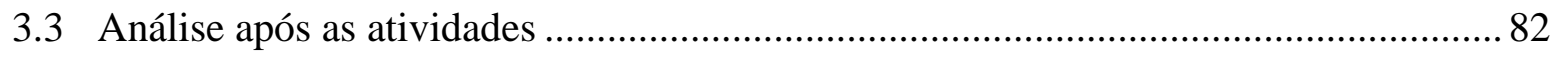

3.3.1 Aplicação dos testes (Testes de Retenção) e a análise dos resultados .............. 83 


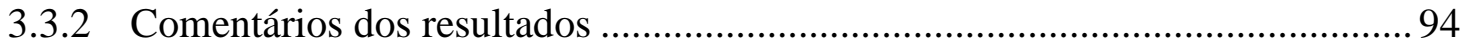

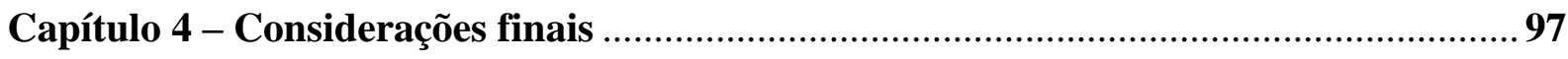

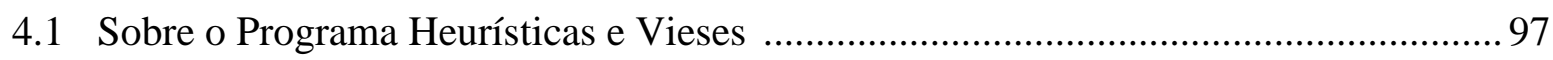

4.2 Sobre a experiência com Educação Estatística ........................................................ 99

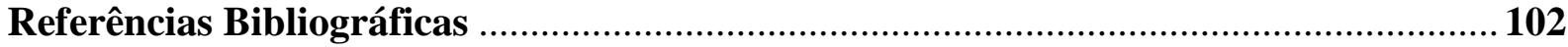




\section{LISTA DE FIGURAS}

Figura 1 - Panorama conjunto das estimativas para probabilidades ................................57

Figura 2 - Justificativas para Vendedor/Advogado para probabilidades no I.Q. ..............58

Figura 3 - Justificativas para as profissões de fazendeiro, engenheiro e físico no I.Q......58

Figura 4 - Probabilidades estimadas para os três tipos de sequências de moedas ..............60

Figura 5 - Justificativas para a sequência CCCCKC ....................................................... 61

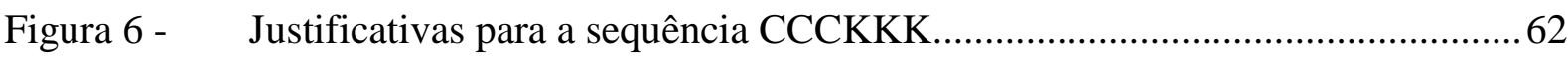

Figura 7 - Panorama conjunto das estimativas para probabilidades nas questões 4,5 e 6.65

Figura 8 - Justificativas para as probabilidades dos eventos das questões 4,5 e 6 ...........65

Figura 9 - Resultados paraas médias estipuladas com as justificativas ............................ 67

Figura 10 - Resultados para as probabilidades estimadas para os itens a,b e c ...................69

Figura 11 - Justificativas para a probabilidade de gostar de esporte e gênero masculino ... 70

Figura 12 - Sequências de jogadas encontradas nos quadros negros pelas turmas .............56

Figura 13 - Comparação geral para as profissões antes e depois das atividades .................8 84

Figura 14 - Justificativas das estimativas da profissão de vendedor após as atividades ..... 85

Figura 15 - Justificativas das estimativas da profissão de físico após as atividades ............86

Figura 16 - Comparativos das estimativas das sequências antes e após as atividades ........89

Figura 17 - Justificativas globais das sequências após as atividades..................................90

Figura 18 - Respostas das sugestões para “a maior certeza da honestidade da moeda"......91

Figura 19 - Comparativo das estimativas das probabilidades antes e após as atividades.... 92 


\section{LISTA DE QUADROS}

Quadro 1 - Matemática versus Estatística: características essenciais ................................22

Quadro 2 - $\quad$ Aplicação do Questionário de Sondagem: aspectos do conhecimento .............54

Quadro 3 - $\quad$ Resumo das heurísticas e vieses detectados.................................................. 73

Quadro 4 - $\quad$ Resumo das propostas e a experiência em sala de aula ..................................... 82

\section{LISTA DE TABELAS}

Tabela 1 - Medidas descritivas das estimativas para probabilidades nas profissões .........57

Tabela 2 - Medidas descritivas das estimativas para probabilidades nas sequências ........60

Tabela 3 - $\quad$ Proporções para a próxima face mais provável. ................................................ 62

Tabela 4 - Estatísticas descritivas para as probabilidades dos resultados ..........................64 64

Tabela 5 - Estatísticas descritivas para a nota esperada do quinto aluno sorteado ............67

Tabela 6 - Estatísticas descritivas para as probabilidades estimadas .................................69 


\section{Introdução}

Ao longo de nossa experiência em sala de aula, nos âmbitos público e privado do ensino básico, bem como do superior, não raro nos deparamos com a dificuldade muito mais acentuada no ensino de probabilidade do que dos demais tópicos de matemática. Seus conceitos e teoria são de difícil assimilação, o que é evidenciado por erros sistemáticos na resolução dos problemas, erros de aplicação e, o mais frequente, de raciocínio.

Os erros de raciocínio em probabilidade e estatística vêm sendo estudados há muitas décadas e revendo esta literatura selecionamos dois dos referenciais que abordam o assunto. Um deles, de Batanero et al.(1994), com ênfase na educação estatística, aponta erros sistemáticos em conceitos estatísticos e por conseguinte em probabilidade. Neste trabalho se destaca a influência de um ensino destes conceitos enquanto tópicos de matemática, por uma abordagem carregada de formalismos e ênfase computacional, bem como uma visão determinística que não se encaixam enquanto visões dos fenômenos aleatórios da natureza carregados de incerteza, onde a presença da variabilidade é dominante.

Outra corrente que destacamos é o trabalho de Tversky e Kahneman (1974), sobre os erros sistemáticos de raciocínio guiados por heurísticas e vieses que compõem padrões mentais que persistem mesmo em pessoas que receberam treinamento em estatística, contendo tópicos de probabilidade em sua formação. Segundo esses autores um aluno, quando tem que decidir diante da incerteza, mesmo de posse de dados e condições para julgar e estimar a probabilidade de um determinado evento, acaba por julgar de forma sistemática guiado por fenômenos padronizados.

Face a esta realidade, o objetivo deste trabalho é investigar e mapear as dificuldades e obstáculos que impedem um melhor desempenho na disciplina, de acordo com o que abordam os autores citados das duas correntes de pesquisas com relação a erros sistemáticos de raciocínio em estatística e probabilidade, para então explorar eventuais caminhos facilitadores, propondo entre outros meios, atividades para a sala de aula. Ao final, analisar possíveis ganhos destas ações.

O trabalho com os alunos foi dividido em dois momentos: primeiro, foi aplicado um questionário de sondagem dos erros de raciocínio sistemáticos citados pelos autores, para em seguida ser aplicado um tratamento dando enfoque à eliminação ou diminuição das heurísticas e vieses de julgamento. Em um segundo momento, aplicamos pós-testes, ou os denominados 
"testes de retenção" (Severino,2007), para verificarmos o que foi adquirido das abordagens e experiências em sala de aula, bem como se foram eliminadas ou até certo ponto diminuídas as heurísticas e vieses no julgamento sob incerteza. 


\section{Capítulo 1}

\section{O referencial teórico}

Apresentamos neste capítulo o referencial teórico que remete a erros e dificuldades encontrados pelos alunos, principalmente quanto ao raciocínio estatístico e probabilístico. No ensino básico, estes erros e dificuldades foram observados enquanto tópicos dentro da disciplina de matemática. Acreditamos que isso se reflita no ensino da probabilidade e estatística na educação básica de âmbito nacional, em particular no estado de São Paulo.

\section{1 - O Ensino de Probabilidade e Estatística na Educação Básica}

$\mathrm{O}$ estudo de probabilidade e estatística, como tópicos dentro da disciplina de Matemática no ensino básico, tem seu início de forma tímida no Ensino Fundamental II (turmas do $6^{\circ}$ ao $9^{\circ}$ ano). A abordagem dentro da matemática faz parte do currículo da Secretaria de Educação do Estado de São Paulo (Currículo do Estado de São Paulo, 2011), e esses tópicos são inseridos como temas para o $4^{\circ}$ bimestre já no $6^{\circ}$ ano, intitulados como "Noções de Estatística", com a leitura e construção de gráficos e tabelas, o cálculo da média aritmética e problemas simples de contagem, com o princípio fundamental de contagem da análise combinatória. No $7^{\circ}$ ano, terceiro bimestre, são indicados problemas envolvendo probabilidade, utilizando as noções de proporcionalidade e porcentagem que constam como tópicos da série. Por último, no $9^{\circ}$ ano, "Probabilidade" é indicada para o quarto bimestre, como último tema, com problemas de contagem e uma espécie de "introdução à probabilidade", como teoria.

O currículo estabelecido aponta para a necessidade do tratamento da informação e da ideia de probabilidade, sendo uma preocupação recentemente incluída. Analisando algumas coleções do Ensino Fundamental II, em edições do ano 2000, como (Mori e Onaga, 2000), verificamos que não havia qualquer referência nos quatro volumes, qualquer ideia que remetesse à probabilidade. Ainda que estes livros apresentassem um material com inúmeras 
propostas de atividades aplicadas com abordagens interdisciplinares, que consistem em desafios e seções livres para uma ampliação das ideias tratadas, nada é mencionado sobre probabilidade nas listas de exercícios.

Em outras coleções mais recentes de obras editadas após novo currículo (Currículo do Estado de São Paulo, 2011), duas delas apresentaram os componentes de modo mais explícito de acordo com esse documento, como a de Giovani Junior e Castrucci (2012) e a coleção escolhida como texto da Secretaria de Estado (Souza, 2012). As coleções apresentam espaços ao "Tratamento da Informação", em todas as séries, com um capítulo especialmente reservado para o tema, com leitura de gráficos e problemas voltados aos cálculos descritivos. A abordagem procura inserir os temas gradativamente, em seus níveis de dificuldade. Na obra de (Souza, 2012), no $7^{\circ}$ ano há um capítulo intitulado "Probabilidade", que percorre cerca de 10 páginas, com exemplos de problemas de equiprobabilidade, como lançamento de dados, problemas de extração de cartas de baralho e bolas de urnas; supondo que as extrações têm a mesma chance de ocorrer sem mencionar isto explicitamente.

Analisando as coleções do ensino fundamental, tanto nos capítulos de noções de estatística, como propriamente a probabilidade, tanto a teoria como as questões analisadas têm exclusivamente a preocupação de o aluno calcular e "acertar" um número, uma quantidade, sem discussão ou qualquer ideia do que estes valores encontrados significam, suas aplicações ou utilizações para qualquer tipo de decisão ou até mesmo, de reflexão. Até mesmo nos capítulos reservados à estatística, não há qualquer menção ao fator erro, ou o que isso vem a significar no tratamento da informação, tal como idealizada pelo currículo; restringindo-se em sua essência a problemas meramente matemáticos, ou determinísticos, levando o aluno a assimilar este tipo de proposta.

Já no ensino médio, os temas são inseridos sob abordagem geralmente axiomática, como encontramos nos livros didáticos, em que há um forte embasamento na teoria dos conjuntos para as demonstrações e para resolução de diversos problemas e exercícios que permeiam o capítulo intitulado "Probabilidade".

Uma obra que destacamos, por exemplo, é a de Giovani (2002) no tema da probabilidade da união e intersecção de eventos. Em um problema, envolvendo uma classe com um número certo de alunos como leitores de dois jornais A e B, são apresentadas as frequências absolutas das pessoas que leem os jornais ora isoladamente, ora simultaneamente; a solução do problema segue uma forma tradicional utilizando o Diagrama de Venn, em que os leitores de cada jornal são separados, isto é, particionados como elementos de dois 
conjuntos. A linguagem utilizada é a da união e intersecção de conjuntos para que o problema seja solucionado e, inclusive, para responder à questão da probabilidade de uma pessoa escolhida ao acaso ser leitora do jornal A ou B. Ao final da página finaliza com a conclusão e generalização para qualquer caso em que haja união de eventos, destacados em uma caixa sombreada com a fórmula da probabilidade da união.

Neste caso, fazer com que os alunos enxerguem os grupos de leitores como conjuntos, é tentar fazer com que tenham uma visão abstrata de uma situação-problema com indivíduos, transformados em elementos de um conjunto. Quando generalizada em uma fórmula, colocada em destaque pela obra, temos uma axiomatização de situações quaisquer que envolvam a união de eventos, algo que pode levar ao erro de se resolver situações particulares de forma geral, de acordo com o artigo de Batanero et. al (1994) que iremos descrever na próxima seção.

Em uma edição mais recente, (Giovani, 2011), os problemas propostos e solucionados são os mesmos, salvo uma pequena introdução levando o leitor a entender que se trata de uma pesquisa sobre a preferência em relação a dois jornais conhecidos $\mathrm{A}$ e $\mathrm{B}$, em que um aluno seria selecionado ao acaso, não sendo alterada toda a forma de resolução. Ainda que o título da obra seja "Matemática Fundamental, Uma nova abordagem", o enfoque do livro se voltou para uma reformulação do projeto gráfico e atualização dos exercícios e testes de vestibulares, permanecendo assim na apresentação em probabilidade de forma axiomática, voltada para a abordagem clássica.

Os problemas não possuem questões discursivas, e as situações ainda são técnicas do ponto de vista da teoria, como no exemplo citado dos jornais, em que a pergunta que se fez no exemplo foi "a probabilidade de uma pessoa ser leitor dos jornais"; sem nenhum tipo de discussão, por exemplo, ao fato "desta pessoa" ser escolhida ao acaso.

Em outra obra para o ensino médio (Smole e Diniz, 2005), no tópico de probabilidade condicional, o tratamento é dado de forma similar, com um exemplo em que o leitor se depara com preferências sobre leitura de jornais e é convidado a calcular a probabilidade sem se discutir do que se trata esta probabilidade, assim como no caso anterior da obra de (Giovani, 2011). A seguir o exemplo:

Numa turma de $2^{\mathrm{a}}$ série do Ensino Médio, sabe-se que 20 alunos leem o jornal X, 23 o jornal Y, 8 são leitores de ambos e 10 não leem nenhum deles. Vamos calcular a probabilidade de: 
a) um aluno dessa turma ler $\mathrm{X}$ e $\mathrm{Y}$

b) um aluno, que lê $X$, ser leitor de $Y$.

c) um aluno, que lê $Y$, ser leitor de $X$.

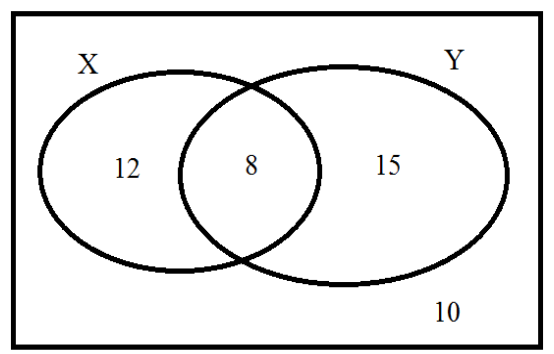

Solução do caso (a): o espaço amostral S é formado por todos os alunos dessa turma de $2^{\circ}$ ano, $\log 0, \mathrm{n}(\mathrm{S})=45 \mathrm{e}:$

$P(X \cap Y)=\frac{n(X \cap Y)}{n(S)} \Rightarrow P(X \cap Y)=\frac{8}{45}$

As autoras fornecem o espaço amostral destacando o Diagrama de Venn ilustrado ao lado do problema, já com a diferença dos leitores que estão na intersecção de $\mathrm{X}$ com $\mathrm{Y}$, e assim dão automaticamente o espaço amostral de $n(S)=45$ para a solução do problema, algo que não é automático, e pode confundir o aluno.

Na resolução do item (b), após o espaço amostral particionado, as autoras sugerem um olhar que diferencie os eventos em suas particularidades, como intersecção e evento simples, por um destaque nas regiões do diagrama:

No caso $\mathrm{b}$, dentre os que leem $\mathrm{X}$, devemos destacar os que leem Y; logo a probabilidade é citada por:

$$
P(Y \mid X)=\frac{n(X \cap Y)}{n(X)}=\frac{8}{20}
$$

Toda a forma de abordar o problema se dá pela notação e linguagem de conjuntos com símbolos para a intersecção dos eventos de interesse, seguidas do cálculo, conclusão e generalização para qualquer caso deste tipo em uma caixa destacada em azul no centro da página, com uma breve descrição sobre a probabilidade condicional.

A excessiva formalidade se torna ainda mais nítida quando as autoras tratam o último tópico de probabilidade, sobre a distribuição binomial, utilizando uma notação excessivamente matemática em uma fórmula destacada para a resolução de quaisquer problemas desta natureza. Claro que a formalização é um recurso elegante, que simplifica a escrita dos conceitos, uma vez que tenham de fato sido apreendidos pelos alunos, o que em geral não é o caso - começa-se pela formalização e não pelo significado. 
Os exemplos de abordagens citados podem gerar inúmeras dificuldades que podem se traduzir como obstáculos no aprendizado, que comprometem, no que diz respeito ao conceito de probabilidade, sua aplicação na resolução de problemas pelos alunos, ou mesmo por futuros pesquisadores que venham a utilizar a probabilidade em seus campos de atuação.

Um aspecto importante ao estudar probabilidade, ainda que matematicamente seja simples de acordo com as operações elementares requeridas pelos problemas, é que interpretar seus resultados requer um novo olhar sobre a matemática, já que os alunos até o segundo ano do ensino médio passaram somente por um estudo determinístico desta disciplina. É necessário mostrar ao aluno um olhar diante da incerteza, pois ainda que se estude e se elabore um modelo teórico para o cálculo de probabilidade, por exemplo do lançamento de uma moeda honesta (probabilidade de Cara = 1/2), que não carrega incerteza enquanto modelo, ao realizarmos um lançamento de uma moeda deste tipo, o resultado é incerto. Ou seja, o aluno se depara com um modelo de previsão de um evento futuro que não lhe garante uma resposta exata ou certa como vinha até então trabalhando na matemática, pois os alunos estudaram diversos tópicos e adquiriram fundamentos e metodologias para encontrarem respostas tidas como exatas dentro dos diversos contextos.

Um exemplo deste determinismo acontece quando, ao estudarem as funções polinomiais de primeiro e segundo graus e seus diversos comportamentos e aplicações, os alunos tem que admitir que as respostas são exatas, isto é, quando repetidos os experimentos ou cálculos em condições semelhantes às criadas pelas funções, conduzem a resultados essencialmente idênticos. Em diversos problemas e situações onde a matemática é aplicada, os resultados obtidos são dados como certos de acordo com o modelo, como por exemplo: a altura de uma árvore de crescimento modelado por uma função logarítmica, o custo de materiais e depreciação de máquinas pela função afim, o número de indivíduos de determinada população que cresce a determinada taxa em modelos exponenciais, bastando apenas trabalhar com o cálculo das variáveis dentro do contexto dos problemas.

Em todos estes exemplos deveria ser considerado um termo aleatório de erro, algo que pode ser comentado ou trabalhado em sala de aula durante o ensino destes tópicos, dado que altura de árvores e comportamento de máquinas são sujeitos a flutuações, o que possibilitaria discutir incerteza e variabilidade, diminuindo o impacto numa discussão inicial sobre a probabilidade. Uma abordagem que pode facilitar este tipo discussão, e por fim ajudar a entender os fenômenos incertos e formular experimentos para estimação, é a abordagem frequentista, ou estatística da probabilidade, já que nesta forma de atuar, iremos propor 
atividades e experimentos os quais, repetidos sob as mesmas condições, produzem resultados geralmente diferentes - são os chamados experimentos aleatórios, que trazem à tona justamente os fenômenos incertos, como a estimação da altura de uma árvore.

São frequentes as perguntas tais como: “Choverá amanhã?”; “Qual será a temperatura máxima para a próxima sexta-feira?" Como o ramo da matemática aplicado ao estudo destes fenômenos é justamente a Teoria das Probabilidades, a estatística também ajuda a tomar decisões com base no que conhecemos de probabilidade e dos modelos teóricos formulados, que requerem concepções e julgamentos diante da incerteza, algo que os livros didáticos até então não discutem nas aulas de matemática, no nível básico de escolaridade.

Quando se tem a oportunidade de ensinar estatística, como tópico de matemática para o terceiro ano do ensino médio, este ensino também se vê prejudicado pela abordagem matemática e computacional das situações, em que os dados parecem meros pretextos para o cálculo, sem contexto.

Vemos em Giovani (2011), no capítulo "Noções de Estatística", uma discussão sucinta na introdução, em que os conceitos de população, amostra e variável são definidos em pouco menos de um parágrafo, condicionando-se simplesmente a defini-los enquanto substantivos. No decorrer do capítulo, as distribuições de frequências são tratadas simplesmente como leituras de gráficos, de caráter técnico e matemático, isto é, são questões em que são indagados a responder por valores que irão calcular sistematicamente de acordo com as técnicas apresentadas, o mesmo ocorrendo para as medidas resumo, como média, mediana e desvio padrão. Em suma, nesta obra não existem questões, ou exemplos de discussões em que as previsões podem ser encontradas fora do nível computacional, e não existem questões que façam o aluno pensar fora do caráter determinístico da matemática; existe sim, uma busca por um resultado, um valor que adquire uma importância superestimada para situações de incerteza. Colocamos aqui um exemplo analisado em outra obra para o ensino médio (Iezzi et al. 2004):

As alturas de um grupo de atletas de um clube estão relacionadas na tabela seguinte...

A tabela é apresentada, e em seguida são feitas duas questões:

a) Determine a média, a classe modal e a mediana dos dados.

b) Encontre a variância e o desvio padrão desses dados. 
O exercício se encerra com estas questões, onde não há nenhum tipo de discussão solicitada, isto é, o aluno não é convidado a participar ou raciocinar estatisticamente.

\subsection{Erros e Dificuldades no Aprendizado de Conceitos Estatísticos}

Pensando em uma forma de abordagem diferenciada, verificamos no estudo de Batanero et al. (1994), a grande ênfase dada à estatística em diferentes currículos, por exemplo, nos Estados Unidos, Reino Unido e Espanha, que requerem um intensivo preparo de professores, pois muitos deles precisam aumentar seus conhecimentos tanto da estatística em si, como na melhor forma de ensiná-la. Este preparo deve também incluir o conhecimento das dificuldades e erros dos estudantes, vivenciados durante o ensino dos tópicos de estatística. Ainda segundo o artigo, há um recente interesse entre educadores em explorar os conceitos dos estudantes, das suas concepções e julgamentos, utilizados frequentemente de forma inapropriada para situações fora de contexto.

O estudo aborda os possíveis motivos para os erros e dificuldades na concepção de conceitos estatísticos, que são permeados por fenômenos em que a variabilidade é fator determinante nos julgamentos e conclusões, e que não permitem naturalmente respostas exatas, mas sim, como os dados tendem a se comportar, e as informações relatadas, segundo o estudo, servem para os processos de aprendizado e desenvolvimento dos currículos ainda como parte da matemática. $\mathrm{O}$ objetivo daquele artigo foi mostrar que erros e dificuldades não nascem aleatoriamente, de maneira imprevisível. Frequentemente é possível descobrir regularidades neles, para encontrar associação com outras variáveis das atividades propostas, dos sujeitos, ou das circunstâncias presentes e passadas, e mostrar as dificuldades encontradas pelos alunos.

Os alunos, segundo o estudo, mostram resistência em substituir seus conceitos usados para resolver determinados tipos de problemas, utilizando-os para situações gerais, e esta resistência torna-se o que alguns autores denominam de obstáculo. Obstáculos são definidos por Brousseau (1983, apud Batanero et al. 1994) e classificados em três tipos quanto à sua origem. Batanero nesse artigo apresenta essa caracterização e os coloca em destaque fazendo uma analogia com os exemplos vivenciados no ensino de probabilidade e estatística: 
1. Ontogênicos (em alguns casos chamados de obstáculos psicogenéticos), ligados às formas de desenvolvimento da criança. Como exemplo, o raciocínio proporcional é necessário à compreensão da ideia de probabilidade.

2. Didáticos, que nascem das opções didáticas escolhidas em situações de aprendizado. Por exemplo, introduzir novas notações como o somatório, quando os estudantes precisam trabalhar com exemplos concretos.

3. Epistemológicos, intrinsecamente ligados ao conceito em si, e que levam parte do significado do conceito. Por exemplo, os diferentes conceitos de probabilidade (clássica, subjetiva, etc), que necessitam de uma definição axiomática.

Obs: Esta abordagem não será retomada neste trabalho e está apenas descrita aqui a título de ilustração.

No trabalho de Batanero et. al (1994), foram investigados diversos tópicos de estatística, como as tabelas de freqüência, representação gráfica dos dados e seus diferentes níveis de compreensão; o resumo de distribuições, como medidas estatísticas, tais como as de tendência central e dispersão, e ainda, associação e regressão e os testes de hipóteses. Esse trabalho enfatiza um tópico importante para o ensino médio, que são as medidas estatísticas, ligadas ao conceito da estimação assim como o objetivo em probabilidade.

No primeiro caso mostrado por Batanero, um exemplo importante para mostrar o quanto a visão matemática impede um raciocínio correto diante da variabilidade, é o cálculo da média, um conceito aparentemente simples em que são apontados erros no cálculo de dados agrupados, em que frequentemente se divide a soma dos valores observados pelo número de grupos e não pelo total de observações. Como é dada grande ênfase computacional na análise de dados, não se observa o contexto numérico, como a seguir:

Há dez pessoas em um elevador, quatro mulheres e seis homens. O peso médio das mulheres é de $54 \mathrm{~kg}$ e a dos homens é de $81 \mathrm{~kg}$. Qual é a média do peso das dez pessoas no elevador?

Neste caso, observou-se que trata-se de duas distribuições de peso envolvidas, algo que não foi notado pelos alunos, e uma possível explicação para os erros é que os estudantes assumem que um conjunto de números junto com as operações aritméticas da média 
constituem um Grupo matemático satisfazendo os axiomas de fechamento, associatividade, elemento inverso e neutro.

Batanero enfatiza que esta crença é falsa, já que de acordo com a definição de Grupo, não satisfaz a propriedade do elemento neutro, ou seja, ao adicionarmos o número zero a média será alterada; e também não satisfaz a propriedade de associatividade, pois se tomarmos uma sequência de três números distintos, a média dos dois primeiros números será diferente se tomarmos os últimos dois números primeiro.

Assim, temos o efeito de uma educação estatística visivelmente afetada pelo nível formal da matemática, fora do contexto do problema. No exemplo citado o cálculo correto seria:

$$
\text { média de peso }=\frac{(4 \times 54)+(6 \times 81)}{4+6}=\frac{702}{10}=70,2 \mathrm{~kg}
$$

enquanto que os alunos frequentemente calculam:

$$
\text { média de peso }=\frac{54+81}{2}=\frac{135}{2}=67,5 \mathrm{~kg}
$$

Outro exemplo, ainda dentro do problema da média foi mostrado no estudo de Batanero:

É sabido que a média das notas da população de um colégio de ensino médio é de 400 . Tome uma amostra de 5 estudantes deste colégio. Os primeiros 4 estudantes de sua amostra tiveram as seguintes notas observadas: $380,400,600,400$. Qual é a nota que você espera para o quinto estudante?

A resposta dita "correta" pela autora Batanero, ou a que se espera diante do problema é 400, pois se trata do valor esperado da população. No entanto, alguns estudantes pensaram que a melhor estimação seria pela média dos 4 estudantes do que pelos 400 da população.

Neste problema, foram apontados distintos tipos de entendimento de um conceito: $o$ instrumental que consiste em ter uma coleção de regras isoladas para resolver problemas específicos, enquanto que o relacional consiste em ter sistemas adequados disponíveis para uma gama maior de problemas. No caso do exemplo, o problema foi relacional, pois não se levou em consideração o conceito de média de uma população, voltando sua atenção aos 
números da amostra. No entanto neste caso é discutível qual a resposta "certa", uma vez que se trata de previsão, sempre associada a uma margem de erro.

A média é tida como o "valor típico" ou "representativo" de uma distribuição, e por essa razão há uma tendência em situá-la no centro da distribuição dos dados, algo que é verdadeiro para uma distribuição simétrica, o que não é o caso do exemplo do elevador, em que há um maior número de homens, tornando-a assimétrica com relação ao peso dos homens. Assim, de acordo com o estudo que contemplou alunos do ensino fundamental e médio, os problemas apresentados nos exemplos se devem à falta de compreensão da média como medida de localização de tendência central em uma distribuição. Novamente, o aluno encara a média como uma medida exata, o que de fato quanto ao cálculo o é, porém o problema está na inabilidade em resolver situações deste tipo, em como se utilizam desta medida, já que eles adquiriram apenas o conceito formal, computacional da média.

Estes aspectos das dificuldades cognitivas dos conceitos de estimação e interpretação da média foram exemplos retirados do estudo que aborda uma gama mais ampla do ensino de estatística, mas que, no caso deste trabalho, corroboram para a ideia dos problemas que o estudo axiomático e de aspecto matemático da disciplina de probabilidade, assim como também da estatística, levam os estudantes a julgarem e concluírem de forma equivocada as soluções dos problemas. São eles influenciados ora pelo aspecto computacional e calculista das medidas e estimativas, ora pela influência e a dimensão que os números tomam e levam a generalizações enganosas, quando fora do contexto.

\section{3 - O raciocínio matemático versus o raciocínio estatístico}

Ainda procurando novas formas de abordagens no ensino de probabilidade e estatística, buscamos observar outro aspecto na tentativa de torná-lo ainda mais efetivo, analisando a ligação do conteúdo e a forma como é abordado em sala de aula. A ideia, em suma, é comparar os principais aspectos que diferenciam as abordagens e formas de raciocínios da matemática e da estatística/probabilidade.

No artigo de Batanero et al.(2011), a variabilidade é citada como ingrediente definitivo no pensamento estatístico, além de ser apresentada uma espécie de "tensão" entre a 
matemática na escola básica e o pensamento estatístico, considerando as formas como os tópicos são abordados e que são os mesmos que iremos destacar nesta reflexão.

O artigo descreve o processo da visão estatística que baseia-se em padrões que distinguem a estatística da matemática, e cita que de acordo com educadores em estatística, estas diferem em suas características essenciais, que elencamos a seguir de forma resumida e adaptada do texto original, conforme o Quadro 1:

\begin{tabular}{|c|c|c|}
\hline Ideia Fundamental & Na Matemática & Na Estatística \\
\hline Os dados & $\begin{array}{l}\text { - Usados no contexto de "olhar os } \\
\text { números" e no estudo das funções; } \\
\text { - Medidas em escalas padronizadas } \\
\text { sem erros; } \\
\text { - Entram como uma aplicação das } \\
\text { regras em probabilidade. }\end{array}$ & $\begin{array}{l}\text { - Contexto do "entre" e "através" } \\
\text { dos dados; } \\
\text { - Medidas consideram erros e seus } \\
\text { atributos; } \\
\text { - Dados são utilizados para se } \\
\text { desenvolver a ideia de } \\
\text { probabilidade. }\end{array}$ \\
\hline Variação & $\begin{array}{l}\text { - Ensinada como precisa e exata. } \\
\text { - Assume-se que os dados seguem } \\
\text { um modelo sem erros. }\end{array}$ & $\begin{array}{l}\text { - Ensinada como "ruído", isto é, } \\
\text { para se medir e controlar a } \\
\text { variabilidade. } \\
\text { - Dados reais são contextuais tendo } \\
\text { incerteza e erro. }\end{array}$ \\
\hline Representação & $\begin{array}{l}\text { - Aglomerados de números sem } \\
\text { representação visual destes. } \\
\text { - Gráficos usados para mostrar as } \\
\text { mesmas relações em diferentes } \\
\text { representações (tabelas,símbolos). }\end{array}$ & $\begin{array}{l}\text { - Estatísticos iniciam com um } \\
\text { gráfico. } \\
\text { - Gráficos para identificar diferentes } \\
\text { aspectos dos mesmos dados. }\end{array}$ \\
\hline Associação e modelagem & $\begin{array}{l}\text { - Coordenadas cartesianas para o } \\
\text { desenho dos gráficos. }\end{array}$ & $\begin{array}{l}\text { - Nuvens de pontos de dados } \\
\text { bivariados, podendo ser uma } \\
\text { ponte com a matemática para se } \\
\text { verificar a autenticidade de um } \\
\text { modelo. }\end{array}$ \\
\hline Modelos Probabilísticos & $\begin{array}{l}\text { - Abordagem formal; } \\
\text { - Subestimam a conjectura } \\
\text { estatística; } \\
\text { - Dependem de suposições, como } \\
\text { independência } \\
\text { equiprobabilidade, o que nem } \\
\text { sempre é assegurado, considerado } \\
\text { ou verificado. }\end{array}$ & $\begin{array}{l}\text { - Modelos de processos geradores } \\
\text { de dados, podendo ser utilizados, } \\
\text { por exemplo, no sorteio aleatório } \\
\text { de amostras de uma população. }\end{array}$ \\
\hline Decisão & $\begin{array}{l}\text { - Concluir seguindo dedutivamente } \\
\text { de definições. } \\
\text { - O raciocínio independe dos dados. } \\
\text { - A prova gera certeza. }\end{array}$ & $\begin{array}{l}\text { - Raciocínio é praticamente } \\
\text { indutivo e conclusões sempre } \\
\text { incertas. O grau de confiança em } \\
\text { uma conclusão depende da } \\
\text { integridade do processo. }\end{array}$ \\
\hline
\end{tabular}

Quadro 1: Matemática versus Estatística: características essenciais (adaptado de Batanero et al. 2011) 
Destacamos um importante aspecto dado pelos autores (Franklin,2012 apud Batanero et al. 2011):

A tendência central de uma variável aleatória ou a variabilidade dos dados em estatística opõem-se à natureza determinística da matemática, e do seu contexto; em estatística o contexto gera significado, já em Matemática, o contexto gera oportunidades de aplicações.

Por fim, ainda Batanero et al.(2011) sugerem que a probabilidade deve ter ênfase apenas na maneira como é utilizada no pensamento estatístico, corroborando com o uso de uma abordagem mais frequentista da probabilidade.

Ainda segundo o artigo:

“[...] quando estudantes veem probabilidade com uma abordagem formal, aprenderão formalismos sem entender o fenômeno descrito pelos matemáticos. Além disso, ensinar probabilidade pode ser enriquecido por amplas experiências fenomenológicas, como a simulação."

Um ponto fundamental segundo o artigo é a preparação dos professores para ensinar as ideias fundamentais de probabilidade e estatística, já que na maioria dos países ela não é separada da matemática, e é ensinada por professores de matemática. Reitera ainda que quando ocorre o treinamento para se ensinar probabilidade e estatística, isto alcança um maior desenvolvimento profissional da prática dos professores, pois habitualmente a matemática inclui múltiplos pontos de vista, uma mistura de dedução e experimentação, procura por padrões e suposições.

\section{4 - Julgando sob Incerteza: O Programa Heurísticas e Vieses}

De acordo com o livro organizado por Kahneman, D. et al. (1982), um amplo estudo, hoje denominado "Programa Heurísticas e Vieses", se originou em três linhas de pesquisa desenvolvidas por volta dos anos 1950 e 1960 por profissionais da área da psicologia: a comparação de predições clínicas e estatísticas; o estudo da probabilidade subjetiva no paradigma Bayesiano; e a investigação de heurísticas e estratégias de raciocínio. Dois dos 
autores, Amos Tversky e Daniel Kahneman, ficaram à frente do programa para o qual convergiram as linhas de pesquisas, estudando e documentando vieses de pensamento intuitivo em atividades variadas, trazendo demonstrações e fornecendo a pesquisadores de diversas disciplinas - notadamente filósofos e economistas - uma oportunidade incomum de observar possíveis falhas em suas próprias opiniões.

O termo "heurística" é descrito nos dicionários da Língua Portuguesa da seguinte forma:

Aurélio(1986) (substantivo): Conjunto de regras e métodos que conduzem à descoberta, à invenção e à resolução de problemas. Cf. Heureca.

Larousse (1998): como adjetivo diz-se de uma hipótese de trabalho adotada provisoriamente, como ideia diretriz, na pesquisa dos fatos; método pedagógico que leva o aluno a aprender por si mesmo a verdade que se lhe quer ensinar.

Caldas Aulete (1958): Substantivo. Faculdade de inventar, descobrir.

Entendemos heurística como um método, ou conjunto de regras para se chegar ao conhecimento, embora Kahneman (2012) sugira seu uso da seguinte forma:

A definição técnica de Heurística é um procedimento simples que ajuda a encontrar respostas adequadas, ainda que geralmente imperfeitas, para perguntas difíceis.

Heurística é utilizada pelos autores como uma regra simplificadora, isto é, uma "regra de bolso", como um princípio geral baseado mais na experiência do que na teoria, de fácil aplicação, mas não necessariamente preciso, para aferir ou calcular algo. Regras de resolução de problemas, como por exemplo, as apresentadas por George Polya, em sua obra "A arte de resolver problemas", Polya (1978) - estratégias de resolução como verificar o que está sendo pedido pelo problema, em seguida as informações fornecidas e suas restrições - são regras, inclusive como citadas pelos dicionários, diferentes das citadas por Kahneman e Tversky, pois no caso de Polya estas são escolhidas e não utilizadas de forma automática pelo sistema cognitivo, que é o foco do estudo dos autores no Programa Heurísticas e Vieses.

Já a palavra "viés", no artigo original na língua inglesa bias, é utilizada tanto em estatística como também (segundo os autores) na psicologia cognitiva, no sentido de "tendenciosidade, preconceito, tendência, propensão, inclinação". Assim, o programa 
"Heurísticas e Vieses" remete aos tipos de regras automáticas que podem levar a erros de julgamento e decisão (deixando claro que as heurísticas nem sempre levam a erros).

Os mesmos autores, Kahneman e Tversky, citam que muito da recente literatura em julgamento e raciocínio indutivo se concentra em erros, vieses e falácias em uma variedade de padrões mentais. Segundo o trabalho, a ênfase no estudo de erros é característica da pesquisa do julgamento humano. Primeiro, são expostas nossas limitações intelectuais e propostos caminhos para melhorar a qualidade de nosso pensamento. Segundo, erros e vieses frequentemente revelam processos psicológicos e procedimentos heurísticos que dominam o julgamento e inferência. Terceiro, enganos e falácias ajudam a mapear as intuições humanas por indicarem como os princípios de estatística e mais ainda da probabilidade são contraintuitivos ou não-intuitivos.

O artigo que destacamos do Programa Heurísticas e Vieses, é especificamente sobre o julgamento sob incerteza - Tversky,A. e Kahneman,D.(1974) - que relata as experiências de uma pesquisa sobre as decisões das pessoas, que são baseadas em opiniões que contêm apenas ideias aproximadas de eventos incertos como numa eleição, ou na culpa de um réu, ou o valor futuro do dólar. Essas opiniões se expressam de forma numérica ou em probabilidade subjetiva. Mas, como as pessoas criam probabilidade de um evento incerto ou uma quantidade incerta? $\mathrm{O}$ artigo mostra como as pessoas se apoiam em um número limitado de princípios heurísticos que reduzem o trabalho complexo de fornecer probabilidade e predizer valores por simples julgamentos. Em geral, esta heurística é proveitosa, mas por vezes leva a sérios erros sistemáticos. O aluno, mesmo de posse de dados e condições de julgar e estimar a probabilidade de determinado evento, acaba por julgar diante da incerteza de forma sistemática. A seguir duas das principais heurísticas serão descritas detalhadamente, que são a Representatividade e a Disponibilidade.

\subsection{1- Representatividade}

A primeira heurística é o que os autores Tversky,A. e Kahneman,D.(1974) denominaram "Representatividade", definida da seguinte forma :

"Representatividade é uma avaliação do grau de correspondência entre uma amostra e a população, entre um resultado e um modelo. O modelo pode referir-se a uma pessoa, a uma 
moeda, ou à economia mundial, e os respectivos resultados podem ser o estado civil, a sequência de caras e coroas, ou o preço atual do ouro".

Assim, indicam que a maioria das questões de probabilidade é do tipo: "Qual a probabilidade que o objeto A pertença a uma determinada classe B?"; “qual a probabilidade que o evento A se originou do processo B?"; e ainda "qual a probabilidade do processo B ter gerado o evento A?" As pessoas então, ao responder às questões, utilizam a heurística de representatividade, em que as probabilidades são estimadas pelo grau que A representa (se assemelha) a B. Sendo A muito representativo de B, a probabilidade que A originou B é julgada como alta, etc. Para ilustrar o julgamento pela representatividade, o artigo expõe o seguinte caso:

Considere um indivíduo que foi descrito por outro como segue: Steve é muito tímido e retraído, invariavelmente prestativo, porém desinteressado nas pessoas ou no mundo real, uma alma meiga, que necessita de estrutura, ordem e tem paixão por detalhes. Como as pessoas avaliam a probabilidade de que Steve esteja envolvido em uma ocupação particular de uma lista de possibilidades (por exemplo, fazendeiro, vendedor, piloto comercial, bibliotecário ou médico)? Como as pessoas ordenam essas ocupações da mais para a menos provável?

$\mathrm{O}$ artigo menciona que na heurística da representatividade, a probabilidade de que Steve seja um bibliotecário, por exemplo, é avaliada segundo o grau em que ele é representativo de, ou similar a, o estereótipo de um bibliotecário. Ainda, a pesquisa realizada no trabalho ou em outros trabalhos do Programa Heurísticas e Vieses com problemas desse tipo mostrou que as pessoas ordenam as ocupações pela probabilidade e pela similaridade exatamente da mesma forma. Essa abordagem do julgamento da probabilidade leva a graves erros, pois a similaridade, ou representatividade, não é influenciada por diversos fatores que decerto afetarão os julgamentos de probabilidade.

A semelhança da personalidade de Steve com a de um bibliotecário estereotipado vem à mente das pessoas na mesma hora, mas considerações estatísticas igualmente relevantes quase sempre são ignoradas. Ocorre às pessoas que há muito mais vendedores do que bibliotecários? Este fato deveria entrar de qualquer forma na estimação de probabilidade de Steve ser vendedor do que bibliotecário, e foi ignorado.

No caso específico dos alunos do ensino básico no Brasil, qual a resposta que se espera em um problema como este, onde inicialmente, como no caso deste trabalho, não estão disponíveis conhecimentos em probabilidade? Acrescente-se ainda, que os alunos são provenientes de uma tradição escolar em matemática com questões fechadas, sem questões 
discursivas e reflexivas, que privilegia a busca por uma resposta exata. Será que os alunos apresentariam os erros sistemáticos assim como no experimento de Tversky e Kahneman?

Dentro desta heurística de representatividade, descrevemos algumas categorias descritas no trabalho de Tversky e Kahneman (1974) que procuramos identificar em nosso trabalho.

Insensibilidade à probabilidade a priori de resultados (Falácia da taxa-base). Um dos fatores que não exerce qualquer efeito na representatividade, mas que deve ter um grande efeito na probabilidade, é a probabilidade a priori, ou frequência de taxa-base, dos resultados. No caso citado anteriormente de Steve, por exemplo, o fato de que há muito mais vendedores do que bibliotecários na população (esta é a denominada taxa-base da população em referência, ou seja, as frequências das profissões como base para uma estimação) deveria integrar qualquer estimativa da probabilidade de que Steve seja um vendedor, e não um bibliotecário. Considerações da frequência de taxa-base, entretanto, não afetam a semelhança de Steve com os estereótipos de bibliotecários e vendedores. Se as pessoas avaliam a probabilidade por representatividade, portanto, as probabilidades a priori serão negligenciadas.

$\mathrm{O}$ artigo descreve como foi testada a insensibilidade em uma condição experimental em que as probabilidades a priori foram informadas, isto é, a proporção de vendedores e bibliotecários. Em um primeiro momento não foi apresentado nenhum tipo de informação, então os participantes usaram as proporções corretamente segundo a lógica de probabilidade, apoiando-se nas taxas-base. No segundo momento, foi apresentado então um esboço de personalidade, e assim julgaram a probabilidade de que um indivíduo desconhecido tivesse maior chance de acordo com a similaridade do estereótipo, efetivamente ignorando as probabilidades a priori.

Um ponto importante a ser observado para o nosso trabalho, é o "perfil" ou "tipo" de pessoa que deve se preocupar em fazer julgamentos em probabilidade. Se esta pessoa tem pela frente um julgamento sob incerteza sem qualquer preocupação em sua estimativa, como o caso de um jogador, ou se sua tomada de decisão não afetará a saúde ou mesmo a vida de outras pessoas, então nestes casos, qualquer valor de probabilidade entre 0 e 1 é viável, mesmo sendo longe da realidade, pagando-se o preço por esta previsão. No entanto, tomadas de decisões em políticas públicas, na área de diagnóstico médico ou de medicamentos, devem invariavelmente se ancorar nas taxas-base, e no caso do nosso trabalho, o aluno formado como cidadão crítico, ou futuro profissional, deve ser orientado neste aspecto, já que a 
minimização do erro de previsão é desejável. Kahneman (2012), descreve a forma como esta negligência deve ser encarada:

Se a probabilidade de chover amanhã é atribuída por você, então esta probabilidade terá seu grau subjetivo de crença, mas para serem úteis, as crenças devem ser restringidas pela lógica de probabilidade.

Concepções Errôneas das Chances: As pessoas esperam que uma sequência de eventos gerada por um processo aleatório representa características essenciais desse processo mesmo quando a sequência é curta. Ao considerar lances de uma moeda (assumidamente honesta) para obter cara $(\mathrm{K})$ ou coroa $(\mathrm{C})$, por exemplo, as pessoas encaram a sequência KCKCCK como mais provável do que a sequência KKKCCC, que não "parece" ser aleatória, e também como mais provável do que a sequência KKKKCK, que para elas não representa a imparcialidade da moeda. Desse modo as pessoas esperam que as características essenciais do processo estejam representadas não apenas globalmente na sequência inteira, mas também localmente em cada uma de suas partes.

Insensibilidade à previsibilidade: As pessoas às vezes são obrigadas a fazer previsões numéricas como o futuro valor de uma ação, o preço do dólar, ou o resultado de uma partida de futebol. Tais previsões são com frequência feitas por representatividade. Por exemplo, suponha que mostrem a uma pessoa a descrição de uma empresa e peçam a ela para predizer seu futuro lucro. Se a descrição da empresa é muito favorável, um lucro muito alto parecerá mais representativo dessa descrição; se a descrição é medíocre, um desempenho medíocre parecerá o mais representativo.

A ilusão de validade: Como descrito anteriormente, as pessoas muitas vezes fazem previsões selecionando o resultado (por exemplo, uma ocupação) que é o mais representativo da informação (por exemplo, a descrição de uma pessoa). A confiança que depositam em sua previsão depende primordialmente do grau de representatividade (ou seja, da qualidade da equiparação entre o resultado selecionado e a informação), com pouco ou nenhum interesse pelos fatores que limitam a precisão preditiva. Assim, manifestam grande confiança na previsão de que uma pessoa é uma bibliotecária, quando veem a descrição de sua personalidade que combine com o estereótipo de bibliotecários, mesmo que a descrição seja escassa e não confiável. Esta confiança injustificável pode ser chamada de ilusão de validade. 
Os autores citam que esta ilusão persiste mesmo quando quem julga tem consciência dos fatores que limitam a precisão de suas previsões, o que será discutido na análise dos resultados na seção 3.3.2.

\subsection{2 - Disponibilidade}

A outra tendência citada no trabalho de Tversky e Kahneman (1974), é a heurística de "disponibilidade", em que são comuns situações em que se estima a frequência de uma classe ou a probabilidade de um evento pela facilidade com que os casos ou ocorrências podem ser trazidos à mente. Por exemplo, avaliar o risco de ataque cardíaco pela lembrança da ocorrência em um familiar ou pessoa próxima. Da mesma forma se estima a probabilidade que um dado negócio venha a falir é imaginar as várias dificuldades que a empresa irá encontrar. Essa heurística de julgamento é chamada de disponibilidade. É uma pista útil para estimar a frequência ou probabilidade, pois ocorrências de classes amplas (modais) são geralmente recordadas melhor e mais rapidamente do que ocorrências de classes menos frequentes.

Todavia, disponibilidade é mais afetada por outros fatores do que apenas a frequência com que um experimento se comporta, consequentemente, a confiança na disponibilidade leva a vieses previsíveis, dos quais destacamos o seguinte caso:

Vieses devido à recuperabilidade das ocorrências: quando a frequência de uma classe é julgada pela disponibilidade de suas ocorrências, uma classe cujas ocorrências são facilmente recuperáveis parecerá mais numerosa do que uma classe de igual frequência cujas ocorrências são menos recuperáveis. Além disso, fatores como evidência, afetam lembranças de exemplos. Como exemplo, o autor cita que o impacto de ver um incêndio afeta muito mais profundamente a probabilidade subjetiva de uma pessoa para acidentes do que o impacto de sua probabilidade ao ler sobre um incêndio em um jornal. Ainda, ocorrências recentes são relativamente mais ativas em julgamentos do que antigas, como por exemplo, proximidade de ter testemunhado acidentes de tráfego. 
O Programa também apresentou reações negativas, como as do psicólogo Gerd Gigerenzer (1994), tido pelos próprios Amos Tversky e Daniel Kahneman como seu mais contundente crítico negativo ao programa, o que será visto na próxima seção.

\section{5 - Crítica ao Programa Heurísticas e Vieses : A representação da informação}

O psicólogo alemão Gerd Gigerenzer (1994), é o crítico mais persistente ao Programa Heurísticas e Vieses. O foco principal da crítica de Gigerenzer é o fato que, de acordo com Tversky e Kahneman, os seres humanos foram programados para serem sistematicamente, teimosamente irracionais ao fazer decisões sob incerteza - pelo menos, na maior parte do tempo. Esta crítica observa também que a psicologia cognitiva, desde o início do Programa Heurísticas e Vieses tornara-se quase sinônimo da investigação do irracional. A crítica do autor é contundente e por vezes pejorativa, como pode ser visto a seguir:

\footnotetext{
"Parece que não tivemos a oportunidade de evoluir conceitualmente um intelecto capaz de lidar com a incerteza"; ou ainda, "estes vieses sobre excesso de confiança parecem sugerir que os indivíduos são afetados por desvios sistemáticos da racionalidade”. Gigerenzer (1994).
}

Ao declarar em um artigo que o Programa Heurísticas e Vieses chega até a sugerir que "somos uma espécie cega para a probabilidade", Gigerenzer (1994) abre um debate sobre algoritmos mentais. Segundo ele:

\footnotetext{
Nossa mente está equipada ou não com algoritmos estatísticos corretos? Ou somente com algoritmos impróprios baseados nas regras de heurísticas como a da representatividade?
}

Esta discussão sobre os processos cognitivos responsáveis pelo raciocínio probabilístico, para Gigerenzer, seria incompleta caso se mantivesse ao nível dos algoritmos, corretos ou não, que é o foco do Programa Heurísticas e Vieses, ao sugerir que a mente não consegue implantar automaticamente algoritmos formais. 
A conclusão de Gigerenzer é que algoritmos precisam de informação, e informação precisa de representação (este é o tema central da crítica ao Programa Heurísticas e Vieses). Assim o problema estaria não nos algoritmos e sim, na forma como a informação do problema é passada. Como exemplo, cita o fato de que, ao colocar em um problema "o que é mais provável?", este "provável” pode referir-se a típico, protótipo, frequente, credível, para o peso de uma evidência, de acordo com o dicionário, e a maioria destes significados não se referem às leis de probabilidade.

Para ilustrar que o problema está na informação, o autor (Gigerenzer, 1994) fez um experimento publicado com o título: "Como fazer a falácia da conjunção desaparecer"; em que cita um exemplo do Programa Heurísticas e Vieses, dentro da Heurística de Representatividade, que é a Falácia da Conjunção:

Linda tem 31 anos, sincera e muito brilhante. Ela é graduada em filosofia. Quando estudante, estava frequentemente preocupada com questões de discriminação e justiça social, e também participou de manifestações antinucleares. O que é mais provável?

a) Linda é caixa de banco

b) Linda é caixa de banco e ativista do movimento feminista

Ao serem questionadas as pessoas, segundo o Programa Heurísticas e Vieses, tendem a julgar como mais provável a conjunção dos eventos - ser caixa e ativista - , violando a regra da conjunção em probabilidade, em que esta sempre será menor ou igual à do evento simples, por um viés de representatividade. Em termos probabilísticos poderíamos escrever para eventos A e B do mesmo espaço amostral, $P(A \cap B) \leq P(A)$. Devido ao perfil de Linda como pessoa preocupada com questões de justiça social, a opção que se apresenta mais atraente às pessoas, e por conseguinte construída através da representatividade como mais coerente, é a de Linda ser caixa de banco feminista e não só caixa de banco. Em suma, Linda se encaixa mais na ideia de "caixa de banco feminista"(conjunção) do que no estereótipo de caixas de banco(evento simples).

Gigerenzer então muda o formato do problema e, ao invés de perguntar sobre a "probabilidade", pergunta por julgamentos de frequência, como a seguir:

Há 100 pessoas que se encaixam na descrição acima. Quantas delas são:

(a) caixas de banco

(b) caixas de banco e ativistas do movimento feminista 
A hipótese é a de que, se a mente resolver o problema de Linda pela heurística de representatividade, a mudança de representação da informação não importará, por não alterar o grau de similaridade. Todavia, se houver algum algoritmo estatístico na mente, adaptado para a representação por frequência, então algo marcante deverá acontecer, e a falácia deverá desaparecer.

As violações na pesquisa de Tversky e Kahneman (1983) foram de 85\%, já no estudo de Gigerenzer (1994), estas violações foram de 20\%. Gigerenzer ilustra ainda com mais dois tipos de heurísticas usando a mesma estratégia de mudança na representação da informação, e as violações também diminuem significativamente.

Para finalizar, Gigerenzer se refere às heurísticas como "alegadas ilusões cognitivas estáveis", e observa que as evidências de seus testes servem para confirmar esta previsão. No entanto, não as fazem desaparecer conforme alegava o artigo. Por outro lado, os pesquisadores Kahneman e Tversky responderam que quando iniciaram o programa, questionaram o pressuposto dogmático de que a mente é lógica e racional. No entanto, este embate evoluiu desde então, e hoje o Programa Heurísticas e Vieses possui uma visão muito mais ampla do que no início. Entretanto o fato é que, não estamos interessados em saber qual dos dois pontos de vista está correto, e sim, observamos que nos dois casos, existem apontamentos para fazer com que os erros de julgamento em probabilidade diminuam.

\section{6 - Comentários}

Os exemplos apresentados nas duas referências descritas de Batanero(1994) e Tversky e Kahneman(1974) remetem a erros frequentes cometidos pelas pessoas em geral, bem como observados em profissionais com treinamento relevante em estatística, erros que este trabalho utilizará como fonte para sondar as dificuldades no aprendizado da teoria das probabilidades em si, e seus diferentes conceitos. Já o trabalho de Gigerenzer, mesmo se configurando como uma crítica, tornou-se uma fonte interessante para verificarmos o problema sobre a representação da informação, e o incluímos como mais um referencial deste trabalho.

Diante destes referenciais, a proposta aqui é evidenciar os principais pontos que podem ajudar no aprendizado e, sendo verificados em sala, podem atuar como ponto de apoio para que o aluno entenda as premissas necessárias à estimação em estatística e em 
probabilidade, se pensarmos que estamos diante de pessoas que querem minimizar o erro médio de previsão, ou seja, com comportamento conservador.

Assim, conhecer e discutir a presença destas heurísticas no ambiente escolar é importante para entender como elas funcionam no raciocínio dos alunos em estatística e probabilidade, o que favorecerá a intervenção do professor. 


\section{Capítulo 2}

\section{Metodologia}

Ao longo dos últimos vinte anos, os tópicos de probabilidade e estatística têm sido cada vez mais apontados como essenciais no currículo da educação básica no mundo, de acordo com Batanero e Godino (2004), em que citam o uso cada vez maior para a vida das pessoas ou sua aplicação em outras disciplinas, o que reforça a necessidade do conhecimento estocástico em muitas profissões e/ou na tomada de decisões.

$\mathrm{Na}$ seção 1.2 discutimos os principais erros de raciocínio quando se trata do aprendizado em estatística e probabilidade no ensino básico; ainda de acordo com o artigo citado, existe a necessidade cada vez maior em preparar os professores de matemática para este tipo de conteúdo, e assim o treinamento de professores em estatística tem tido maior destaque para atender estas demandas. Com este intuito, realizaremos neste trabalho uma pesquisa com alunos da escola básica, que poderá servir de apoio ao professor de matemática.

A pesquisa será feita em três momentos: em um primeiro momento, será feita uma sondagem das intuições e raciocínio estatístico e do julgamento dos alunos em probabilidade, onde eles serão instados a estimar probabilidades diante de cenários incompletos, ou diante de informações irrelevantes, tendo que expor suas justificativas para tais estimativas. No segundo momento serão aplicadas atividades propostas para a sala de aula, para serem avaliadas em um terceiro momento quanto ao efeito ante aos erros de raciocínio e intuição.

Por tratarmos de estimações de probabilidade, faremos uma abordagem quantitativa para tratamento e análise dos dados coletados.

\section{1 - Pesquisa Exploratória}

O trabalho utiliza a pesquisa do tipo exploratória, definida por conforme Vasconcelos (2002) da seguinte forma: 
A pesquisa exploratória é aquela realizada em áreas (de conhecimento) ou focada em problemas a respeito dos quais há escasso ou nenhum conhecimento acumulado e sistematizado.

Pela relativamente recente introdução do tema probabilidade e estatística na escola básica, podemos dizer que não há muito conhecimento acumulado, entre os professores brasileiros, do comportamento dos alunos frente a estas questões. Por se tratar de uma pesquisa com foco mais aberto para investigação de fenômenos (culturais, sociais, etc.) pouco sistematizados, ainda segundo o mesmo autor, ela é passível de várias perspectivas de interpretação. Verificar a existência de heurísticas e vieses como possíveis obstáculos no aprendizado de probabilidade e ainda, possíveis meios de diminuição ou eliminação de erros sistemáticos de raciocínio são o foco da pesquisa que busca identificar cursos relevantes de ação.

O trabalho realiza também uma investigação de intervenção, Vasconcelos (2002):

A pesquisa de intervenção é concebida e realizada em estrita associação com uma ação para resolução de um problema coletivo.

A pesquisa de intervenção tem o compromisso de efetivamente resolver problemas de forma participativa.

As estratégias e meios empregados na busca da informação seguiram uma forma que mostrasse, em um primeiro momento, evidências das heurísticas e vieses, e no segundo momento a eficácia das atividades propostas. Assim configurou-se a pesquisa da seguinte forma:

- Pesquisa com dados: os dados foram coletados antes da intervenção e após uma intervenção deliberada para provocar ou verificar uma possível mudança com relação à forma do julgamento por heurísticas e vieses; trata-se de uma pesquisa experimental neste sentido. 
As técnicas e instrumentos de coleta de dados foram do tipo escrita, através de um questionário de sondagem desenvolvido para aplicação antes da intervenção e após a intervenção, com o propósito de descrever as características e formas das heurísticas presentes no raciocínio do aluno em probabilidade e estatística. Após a intervenção, foi realizada uma análise quantitativa para verificar a eficácia das atividades propostas na diminuição destas heurísticas.

Na próxima seção, serão descritas com detalhes as etapas da pesquisa com seus respectivos processos, tendo como objetivo o ensino de probabilidade e estatística.

\section{2 - Planejamento da Pesquisa}

Neste trabalho procuramos verificar se os problemas no ensino de probabilidade e estatística estão relacionados com as ideias apresentadas em nosso referencial que, pela forma como são apresentados, apontam para novas formas de abordagem em sala de aula, além de verificar a eficácia destas abordagens na diminuição ou eliminação destes problemas recorrentes no ensino da probabilidade e estatística.

A seguir daremos uma descrição da sequência do trabalho e a forma com que foi desenvolvido, com as respectivas seções de cada etapa da pesquisa.

Procurando construir e avaliar a eficácia de propostas de intervenção para alunos do $2^{\circ}$ ano do Ensino Médio, esta pesquisa se baseou no levantamento inicial dos dados, utilizando técnica de coleta dos dados através de um questionário em que buscamos evidências que o referencial citado descreve como fatores dos problemas de aprendizado, pois conforme Tversky (1982), erros e vieses de julgamento sob incerteza são a maior fonte de dados para se mapear os limites das intuições estatísticas das pessoas.

Assim, baseados nestas pesquisas, aplicamos um teste que será descrito na seção 3.1.1, contendo os aspectos da sua aplicação, e em seguida, na seção 3.1.2, iremos descrever os aspectos do conhecimento e comportamento dos alunos ante as questões. Queremos então tanto tentar encontrar e relacionar os erros de raciocínio, citados por Batanero (1994) como ainda verificar se existem heurísticas e vieses no julgamento em probabilidade de acordo com a pesquisa de Tversky e Kahneman(1974). 
As respostas solicitadas pelo questionário são de caráter quantitativo e qualitativo, em que tanto foram pedidas estimativas de probabilidade como justificativas por escrito para os valores apontados.

Será apresentada uma análise dos resultados na seção 3.1.3, com ferramentas de estatística descritiva incluindo algumas medidas resumo, gráficos de setores e diagramas de caixa (boxplot). Este último gráfico mencionado, não muito explorado na escola básica, localiza através de um desenho esquemático, cinco valores de estatísticas (de ordem): mediana, $1^{\circ}$ e $3^{\circ}$ quartis, mínimo e máximo (Bussab e Morettin, 2002).

Isto ajudará a buscar algumas evidências sobre a forma como os alunos raciocinaram diante da incerteza para seus julgamentos em probabilidade e estatística.

Logo após feitas as análises, foram propostas atividades e formas de abordagem em sala de aula, descritas na seção 3.2. As atividades foram aplicadas no decorrer do curso ao longo de um bimestre, e nosso objetivo teve como base a seguinte hipótese:

- As atividades propostas e aplicadas em sala de aula podem eliminar, ou diminuir o efeito das heurísticas e as chamadas falácias, que prejudicam o aprendizado de probabilidade.

Para verificar esta hipótese, fizemos um pós teste em um segundo momento, no final do bimestre, após as atividades terem sido aplicadas e trabalhadas em sala de aula. Foi utilizado o Teste de Retenção (Fiorentini e Lorenzato,2006), com três questões consideradas chave (pelo autor deste trabalho), extraídas do pré-teste, com o mesmo conteúdo, que será descrito na seção 3.3.1, para verificar através do tratamento estatístico quantitativo das estimativas e pela análise das justificativas a eficácia destas atividades na diminuição ou talvez eliminação das heurísticas e vieses.

Na seção 3.3.2, na apresentação dos resultados, faremos uma análise final verificando nossa hipótese da eliminação ou diminuição das heurísticas e vieses.

Na seção a seguir serão apresentados os detalhes do questionário de sondagem para o levantamento dos dados. 


\section{3 - Questionário de sondagem}

O questionário é composto de 8 questões que serão descritas detalhadamente, com o respectivo objetivo:

\section{Questão 1:}

Carlos é muito tímido e retraído, mas sempre prestativo e atencioso com as pessoas, necessita de organização e ordem pois é muito detalhista. Para cada profissão abaixo dê a chance de $0 \%$ a $100 \%$ (probabilidade) que, em sua opinião Carlos poderia ter e, em seguida, justifique o valor dado:

a) Vendedor; b) Fazendeiro ou agricultor; c) Físico; d) Advogado; e) Engenheiro.

Esta questão procura sondar o fenômeno da heurística de Representatividade, do trabalho de Kahneman e Tversky (1974), através da chamada Insensibilidade à probabilidade a priori de resultados. Retiramos e adaptamos a questão diretamente do trabalho dos dois autores que, na ocasião, fizeram o experimento apresentando aos voluntários breves descrições de diversos indivíduos, alegadamente retirados de uma amostra aleatória dentre um grupo de cem profissionais - engenheiros e advogados. Foi pedido aos participantes então que avaliassem, para cada descrição, a probabilidade de que ela pertencesse antes a um engenheiro do que a um advogado.

No nosso caso, simplificamos a tarefa para apenas uma descrição, para várias profissões e, assim, a probabilidade estimada mostrará se existe alguma predileção por alguma profissão pelos alunos, o que será corroborado e reforçado por suas justificativas em cada probabilidade estimada por item. Isso indicará se existe uma possível ocorrência na negligência de representatividade, já que o fato de que há muito mais vendedores do que físicos na população a ser considerada pelos alunos (Região Metropolitana de São Paulo), deveria entrar obrigatoriamente na estimação quando se trata de estimar a probabilidade.

Uma possível resposta dada por um aluno seria a de que "não há informações suficientes para fornecer uma resposta", sendo plausível e prontamente aceita dentro das informações escassas às quais foram expostos. No entanto, iremos observar se a confiança depositada em suas estimativas, ou previsões, irão depender do grau de representatividade na 
descrição e, em caso afirmativo, poderá haver outro viés em cena, que é a Ilusão da validade, descrita anteriormente na seção 1.3.1. As respostas dos alunos serão analisadas segundo estas perspectivas.

Um ponto importante descrito no Programa Heurísticas e Vieses, é que o número de mecanismos automáticos realizados por nosso sistema cognitivo é vasto, assim destacamos anteriormente os mais importantes e considerados clássicos e emblemáticos pela corrente de pesquisa.

Para se ter uma outra dimensão, o viés da Ilusão da validade é apenas uma forma específica de um grupo mais amplo na forma de julgar em probabilidade, em que o fato da confiança em sua previsão depender do grau de representatividade é na verdade uma estratégia automática para tentar encontrar uma resposta satisfatória para uma pergunta difícil - no caso a probabilidade de exercer uma profissão -, e automaticamente as pessoas buscam uma pergunta relacionada mais fácil, que o autor Kahneman (2012) chama de pergunta heurística, isto é, é a pergunta mais simples que você responde em lugar da mais difícil. O autor denomina este grupo de julgamentos automáticos de Viés de Substituição, e a ilusão da validade é uma das formas de buscar outra questão mais simples.

Uma questão que pode surgir quando questionamos os alunos com esta primeira questão da sondagem é: “Como as pessoas fazem julgamentos de probabilidade sem saber precisamente o que é probabilidade"? O Viés de substituição é uma plausível explicação, assim como a Ilusão da validade. Mas até que ponto estas heurísticas são estáveis, e podem realmente ser decisivas no julgamento em probabilidade, é uma discussão que faremos sobre o Programa Heurísticas e Vieses (seção 3.3.2), seus resultados e críticas recebidas ao longo das últimas décadas, cujos resultados serão relacionados nesta pesquisa.

Contudo, estando atentos aos mecanismos que levarão os alunos a estimar a probabilidade, teremos um apontamento para ser explorado, na sequência do curso e das aulas, podendo evidenciá-los aos alunos, que assim podem ter uma visão mais clara sobre a forma como julgam ou estimam na incerteza.

\section{Questão 2:}

Considere as sequências abaixo de resultados no lançamento de uma moeda. Em cada caso, forneça a sua estimativa em porcentagem da moeda ser honesta (ou seja, a chance de sair cara 
$\mathrm{K}$ é igual à de sair coroa $\mathrm{C}$ ), considerando que cara e coroa sejam os únicos casos possíveis. Justifique o valor dado por você. (*)
a) $\mathrm{C}, \mathrm{K}, \mathrm{C}, \mathrm{K}, \mathrm{K}, \mathrm{C}$;
b) $\mathrm{C}, \mathrm{C}, \mathrm{C}, \mathrm{K}, \mathrm{K}, \mathrm{K}$;
C) $\mathrm{C}, \mathrm{C}, \mathrm{C}, \mathrm{C}, \mathrm{K}, \mathrm{C}$

Nesta questão, o aluno terá que fornecer uma probabilidade estimada para cada sequência de lançamentos de uma moeda, tendo que colocar sua justificativa para cada valor, de onde será extraído e sondado o fenômeno dentro da Representatividade, chamado no trabalho de Tversky e Kahneman(1974) de Concepções errôneas das chances. Esta questão também foi extraída do trabalho no qual foi perguntado aos participantes apenas "qual a sequência mais provável", e logo fizemos uma pequena adaptação solicitando uma probabilidade para cada item, que foram as mesmas sequências de resultados no lançamento de uma moeda do trabalho citado.

No resultado dos pesquisadores, a sequência CKCKKC foi considerada como mais representativa do que CCCKKK, ou ainda mais que CCCCKC; mostrando que as pessoas não observam globalmente e sim, localmente o processo.

Um outro exemplo é acreditar que a chance de aparecer preto em uma roleta após uma sequência de vermelhos é maior, por acreditar no "equilíbrio dos desvios"; mas o fato é que os desvios com relação à tendência não são corrigidos no processo, e sim diluídos. Os autores ainda citam o fato de que pesquisas indicam que a intuição estatística em experimentos têm mais representatividade em pequenas amostras, o que denominam de "Lei dos pequenos números", também citado no trabalho de Batanero (1994), o que se configura numa alusão contrária a um dos pilares da estatística conhecida como Lei dos Grandes Números, isto é, ao acreditar nesta representatividade da amostra pequena, leva-se a superestimações e interpretações exageradas.

Temos então um cenário em que há apenas 6 lançamentos para cada caso, ou seja, curtas sequências de resultados, onde as respostas esperadas seriam do tipo: "A chance é a mesma"; isto é, todas as três sequências têm a mesma chance de terem sido geradas por moedas honestas, ou talvez "Não posso saber sobre a honestidade com poucos resultados". Certamente essa seria uma resposta adequada.

(*) A questão solicita ao aluno que estime a probabilidade de a moeda ser honesta, isto é, que ele forneça sua percepção da "honestidade" da moeda, usando as sequências fornecidas. No entanto, o enunciado pode levar o aluno a um equívoco de pensar que a probabilidade dela ser "honesta" é a probabilidade de sair cara e, nesse entendimento, se ele oferecesse o valor 0,50 esse seria o valor para a moeda julgada como honesta - o que seria um equívoco. Seria importante a orientação dos alunos durante sua aplicação. 
Novamente, o que se espera da resposta do aluno? Primeiramente, ainda que sem o conhecimento formal de probabilidade, que ele possa indagar antes de sua resposta o que a palavra honestidade implica ao problema. Podemos informar que por honestidade da moeda queremos dizer que há igual chance de sair cara ou coroa em uma moeda deste tipo, uma simples ideia de simetria. Em segundo lugar, poderíamos esperar que ele contasse e comparasse a quantidade de caras com a de coroas para verificar se há igualdade, e neste caso teríamos um esboço da ideia de busca de probabilidade.

Se a heurística da concepção errônea das chances for observada, pode indicar de acordo com a teoria:

A lei dos pequenos números ocorre pelo fato de as pessoas tenderem a exagerar a consistência e a coerência do que veem, uma tendência a confiar em vez de duvidar, uma precipitação por via de fragmentos. (Kahneman, 2012)

Analisando as respostas, assim como no caso da similaridade das profissões, poderemos explorar esta sondagem evidenciando estes principais fatores, tão importantes dada a relação com o conceito de probabilidade em si, para fornecer rumos para o aprendizado de probabilidade.

\section{Questão 3:}

Qual a face mais provável (Cara K ou Coroa C) a sair no próximo lançamento de uma moeda em cada sequência abaixo? (para cada caso coloque a chance de $0 \%$ a $100 \%$ de isso acontecer, C ou K, na sua opinião). Justifique com palavras.

\section{a) $\mathrm{C}, \mathrm{K}, \mathrm{C}, \mathrm{K}, \mathrm{K}, \mathrm{C} ; \quad$ b) $\mathrm{C}, \mathrm{C}, \mathrm{C}, \mathrm{K}, \mathrm{K}, \mathrm{K} ; \mathrm{C}) \mathrm{C}, \mathrm{C}, \mathrm{C}, \mathrm{C}, \mathrm{K}, \mathrm{C}$}

Criamos esta questão como uma ideia variante da questão 2, já que procura sondar a mesma heurística dentro da Representatividade, que são as Concepções errôneas das chances, de um resultado global que caracteriza o comportamento da moeda, sendo honesta ou não. Neste caso, seria uma aplicação deste conhecimento ou reconhecimento da honestidade da moeda, buscando observar se o aluno a reconhece e, por conseguinte, aplica este olhar para procurar prever os próximos resultados da moeda, dado o registro anterior, e o quanto este registro anterior afeta seu julgamento diante da incerteza do próximo lançamento; algo que será retirado de suas respectivas justificativas solicitadas na questão. 
A resposta esperada neste caso para as três sequências, seria que os alunos respondessem que não há preferência para a próxima face, e ainda, poderiam sugerir qualquer resultado realmente, pois o próximo lançamento não depende da Lei dos Grandes Números, pois o problema não trata de convergência, e sim, de um resultado local, ou seja:

O padrão ocorre, e essa relação é um fato matemático: "você pode prever o resultado da amostragem repetida, mas não pode ter certeza sobre uma extração”. (Kahneman,2012), grifo nosso.

O aluno tem em suas mãos fatos "meramente estatísticos" que mostram possíveis resultados, mas não fazem com que aconteçam.

\section{Questão 4:}

Uma loja teve o resultado de suas vendas no $1^{\circ}$ semestre muito ruim. Em sua opinião, qual a probabilidade de que tenha o mesmo resultado no segundo semestre? Justifique sua resposta.

Como última questão para sondagem do viés de representatividade, temos mais um de seus aspectos que é o da Insensibilidade à previsibilidade. Esta pergunta foi extraída do próprio artigo de Tversky e Kahneman (1974), em que mantivemos praticamente o mesmo formato, buscando os mecanismos utilizados pelas pessoas ao fazerem previsões. Se forem afetadas pela insensibilidade à previsibilidade, então o julgamento deverá ser ruim, dada a descrição medíocre da empresa.

A “insensibilidade" descrita pelo viés é o fato de que, não importa o quão confiável sejam as informações ou o grau em que ela permite uma previsão acurada, a descrição não será afetada para a sua utilização no julgamento. Esta forma viola a Teoria Estatística, onde as extremidades e a amplitude das previsões são controladas por considerações de previsibilidade. Na ausência de informação, a mesma chance é aplicada para todos os casos.

Neste caso vamos verificar as resposta dos alunos para previsões em que a descrição não fornece qualquer informação relevante para o lucro, ou resultado das vendas. Temos uma questão de previsibilidade praticamente nula, ou seja, não há informações relevantes, e assim a resposta de que a probabilidade é igual para ambos os resultados "ruim" ou "bom", seria a mais esperada, ou ainda, em uma possível resposta mais sofisticada, um "resultado médio" deve ser previsto para o próximo semestre. 


\section{Questão 5:}

Qual a probabilidade de um detento que cumpriu pena no Brasil ser reincidente? Justifique sua resposta.

Criamos e desenvolvemos esta questão como uma forma mais simples, e mais comum por se tratar de assuntos sociais tão comumente discutidos pela mídia e de acesso aos alunos. A heurística buscada no caso é a da Disponibilidade, (Tversky e Kahneman,1974) e descrita no capítulo anterior como viés devido à recuperabilidade das ocorrências.

Esta heurística remete ao fato de o julgamento ficar comprometido devido à disponibilidade de exemplos, com superestimações ou subestimações das probabilidades de ocorrência, dada a facilidade ou não, com que os exemplos venham à mente. Assim, as classes mais facilmente lembradas aparecem mais do que classes de igual frequência, que são menos lembradas. Nossa busca, no entanto, observa dentro desta heurística, um outro fator como a proeminência, que afeta a recuperabilidade das ocorrências, como no caso da questão de um detento que cumpriu pena no Brasil ser reincidente - temos aqui um assunto que permeia a mídia, levando as pessoas a conclusões e/ou indicações inclusive causais, de que crimes cometidos são desta forma realizados por ex-detentos, ou ainda, que este fator é determinante para a prática de crimes.

No caso dos alunos, ver na mídia constantemente exemplos que se tornam muito mais proeminentes do que os não reincidentes, ou mesmo possíveis exemplos de experiências pessoais como proximidade a ex-detentos ou mesmo de familiares podem levar a superestimações desta probabilidade de ser reincidente no país.

Por fim, a resposta poderia ser qualquer estimativa, dado que não há informações relevantes para um julgamento. Entretanto é importante observar que ao fazer qualquer tipo de previsão - assim como nas questões anteriores -, estamos correndo um risco e, para um indivíduo avesso ao risco, o intuito é correr o menor risco possível.

\section{Questão 6:}

Um fabricante de TV fornece garantia de 1 ano. Qual é, em sua opinião, a probabilidade de uma TV desta marca quebrar um mês após o término da garantia? Justifique sua estimativa.

Temos nesta questão outro exemplo que buscamos sondar do viés de Disponibilidade, em que a estimação é afetada pela lembrança de exemplos. A resposta esperada, diante de um cenário de informações irrelevantes, ou parciais, seria a mais conservadora possível, ainda 
que, conforme já mencionado, várias respostas fossem aceitáveis diante de um julgamento ante a incerteza. Assim, se o aluno responder que a TV "tem a mesma chance de quebrar ou não", estaria com sua resposta conservadora diminuindo o erro da forma mais plausível, pois segundo Tversky e Kahneman(1974), ao se estimar a probabilidade que um dado negócio venha a falir, o indivíduo se põe a imaginar as várias dificuldades que este irá encontrar pela frente, e no entanto, a imaginação pode mostrar uma falha importante na estimação de probabilidade na vida real.

\section{Questão 7:}

Esta questão é uma adaptação daquela já discutida na seção 1.2. Repetimos seu enunciado: suponha que a média das notas de matemátcia em determinado colégio de ensino médio seja 4,0. Tome uma amostra de 5 estudantes deste colégio. Os primeiros 4 estudantes de sua amostra tiveram as seguintes notas observadas: 3,8; 4,0; 6,0 e 2,0. Qual é a nota que você espera para o quinto estudante? Justifique.

Temos nesta questão, além da busca por um diagnóstico dos problemas no cálculo da média, também o conceito de "valor esperado". Segundo Batanero (1994), este conceito não pode estar, na prática, separado da competência computacional. A dificuldade nasce justamente em não acreditar que a média seja estimada sem o auxílio computacional. O artigo fala da distinção entre o "entendimento instrumental"(lidar com uma coleção de regras isoladas para obter uma resposta de problemas específicos) e o "relacional" (ter disponível esquemas suficientes para resolver uma gama maior de problemas). A ênfase computacional na análise dos dados fornecidos pelo problema pode levar à não observação do contexto numérico, que na questão é o valor esperado já fornecido pelo problema para a nota do colégio.

A resposta esperada é a média conhecida e fornecida do colégio. No entanto, como se trata da próxima nota do quinto estudante, qualquer nota poderia ser imaginada, então se for estimada uma nota com a justificativa de que "qualquer nota seria possível", também seria uma resposta plausível diante de um julgamento sob incerteza. Por último, ainda que os alunos calculem a média da amostra fornecida, isto também estaria dentro de um conjunto de respostas possíveis e aceitáveis, mas novamente o que é o mais importante a ser observado nesta questão, bem como nas anteriores, é que, ao julgar sob incerteza, mesmo aceitando qualquer resposta, é importante notar que o risco envolvido em respostas sob certos vieses é maior do que quando se leva em conta a teoria de probabilidade e estatística. 


\section{Questão 8:}

Consideremos 100 alunos que cursam o ensino médio em um colégio distribuídos em relação ao gênero e gosto por esporte. O diretor vai sortear um aluno para representar a escola em um evento da cidade, com a configuração dada a seguir:

\begin{tabular}{c|c|c|c}
\hline \multirow{2}{*}{ Gênero } & \multicolumn{2}{|c|}{ GostadeEsporte } & \multirow{2}{*}{ Total } \\
\cline { 2 - 3 } & Sim & Não & \\
\hline M & 50 & 10 & 60 \\
\hline F & 30 & 10 & 40 \\
\hline Total & 80 & 20 & 100 \\
\hline
\end{tabular}

a) Qual a probabilidade (chance) de que um aluno escolhido seja do gênero masculino e goste de esporte?

b) Qual a probabilidade (chance) de que um aluno escolhido seja do gênero masculino ou goste de esporte?

c) Qual a probabilidade (chance) de que um aluno escolhido goste de esporte, sabendo que é do gênero masculino?

Esta questão solicita o valor de probabilidade, tendo valores disponíveis para o cálculo, mesmo que os alunos tenham tido apenas duas aulas introdutórias com os conceitos básicos e breve prática em sala de aula para o intento.

Nesta questão, a tabela de dupla entrada fornece os dados para o cálculo de probabilidade, em que para o item (a), a probabilidade da intersecção de eventos, ou seja, ser homem e gostar de esporte, é de 0,5(50/100); para o item (b), temos pela probabilidade da união dos eventos, que abrange o aluno ser homem ou gostar de esporte, uma resposta esperada de $0,9[(60+80-50) / 100]$ e por último o item (c), uma questão de probabilidade condicional, isto é, a probabilidade de gostar de esporte sabendo que é do gênero masculino vale 0,83 (50/60). No entanto, os alunos não receberam treinamento para tanto, e neste caso observamos seu comportamento diante dos dados e do enunciado e contexto do problema, que também podem conter um viés de representatividade, como o gênero que pode influenciar os alunos na estimação do gosto pelo esporte. 
Estamos interessados em verificar se o aluno irá negligenciar os dados para a estimação das probabilidades, diante de uma possível representatividade dado o gênero masculino para os esportes. Neste caso utilizamos uma tabela de dupla entrada, como um primeiro contato para o cálculo de probabilidades, sendo que os livros didáticos que citamos não contêm este tipo de abordagem.

Estas oito questões formaram o questionário de sondagem para uma tentativa de mapeamento das intuições estatísticas e probabilísticas dos alunos, e de suas heurísticas e vieses nas correspondentes atividades de estimação. Em resumo, as questões 1 (profissão mais provável), 2 e 3 (sequências de resultados no lançamento de moedas) e 4 (resultado futuro de uma loja) irão sondar a heurística de Representatividade. As questões 5 (ex-detento ser reincidente) e 6 (quebra de uma TV após o término da garantia) irão sondar a heurística da Disponibilidade. A questão 7 (valor esperado para um aluno sendo conhecida a média do colégio) irá sondar os erros de raciocínio estatístico cometidos pelos alunos ao se calcular ou estimar a média; e por último a questão 8 (aluno gostar de esporte) irá medir o entendimento e interpretação dos dados pelos alunos com a abordagem utilizando tabela de dupla entrada e também da possível Representatividade pela descrição do gênero na tabela.

\section{4 - Desenvolvimento da Pesquisa}

A pesquisa efetuada foi realizada, como citado, em três momentos, isto é, um levantamento inicial, em seguida as aulas com abordagens baseadas nas atividades propostas, para no último momento avaliarmos sua eficácia diante das heurísticas e vieses observados. Antes de descrevermos este desenvolvimento, faremos uma breve descrição da estrutura do colégio e a situação das turmas consideradas na pesquisa. 


\subsection{1 - O Caetano de Campos}

Para a pesquisa de campo, foram estudadas três turmas de segundo ano do ensino médio na Escola Estadual Caetano de Campos, no bairro da Aclimação na capital São Paulo. Pela importância dessa escola, por muito tempo referência do ensino público em São Paulo, abriremos nesta seção um parênteses para caracterizá-la. Esta escola, quando fundada em 16 de março de 1846, era denominada Escola Normal Caetano de Campos e funcionava no edifício em que atualmente está instalada a Secretaria da Educação do Estado de São Paulo. A escola foi transferida em 1978 para o bairro da Aclimação, em uma edificação moderna, possuindo uma área de $18.000 \mathrm{~m}^{2}$, antiga sede da Faculdade de Medicina Veterinária da Universidade de São Paulo.

A atual sede possui amplas rampas de acesso aos dois pavimentos para as salas de aula, com amplos saguões de acesso às salas, que remetem à estrutura realmente de uma faculdade. Seu porte é considerado de uma escola grande, possuindo 125 professores que lecionam para os três períodos, com turmas do $1^{\circ}$ ano do ensino fundamental até o $3^{\circ}$ ano do ensino médio, com 6 turmas de primeiro ano, 5 de $2^{\circ}$ ano e 4 salas para o terceiro ano. Sua estrutura conta com um laboratório de biologia e química, uma sala de Artes, quadra poliesportiva, sala de informática, sala de leitura, duas salas de vídeo, sala de livros didáticos, sala de recursos para alunos com necessidades especiais, um auditório com capacidade para 500 pessoas e ainda, um pequeno museu de história, com acervo de documentos e objetos que contam a história do próprio colégio ao longo de um século.

Entretanto, esta estrutura sofre com problemas burocráticos e de falta de investimentos e ações necessárias à sua manutenção, o que vem gradativamente diminuindo o potencial da escola. Como exemplo, o auditório, uma imensa estrutura, foi requerido e transferido à Orquestra Sinfônica Municipal de São Paulo, realizando ensaios regularmente, e o colégio não tem mais acesso, exceto para colação de grau dos seus alunos. $\mathrm{O}$ museu encontra-se fechado e não pertence ao colégio e sim ao Instituto Mário Covas, que está encarregado de catalogar seu acervo e retirá-lo para sua sede, no centro da capital paulista. Algo semelhante ocorre com o laboratório de biologia e química, por conter elementos químicos nocivos ainda da antiga faculdade, que deveriam ser retirados pela Faculdade de Medicina Veterinária da USP, um processo que foi iniciado há mais de dez anos, ainda em fase de execução. Por fim, uma outra estrutura, uma construção circular de cerca de $100 \mathrm{~m}^{2}$, que se configurava também 
como um pequeno auditório em que eram feitos ensaios de peças pelos alunos, está abandonado, e também já foi destituído da escola e requerido pela Polícia Militar de São Paulo para construção de um futuro batalhão no local, obra ainda não iniciada.

Face a essas e outras dificuldades estruturais pelas quais passa o colégio, temos um corpo discente que apresenta muitos problemas no seu rendimento escolar. Observando particularmente as turmas que lecionamos e aplicamos as atividades, no ano de 2014, foram turmas de $2^{\circ}$ ano de ensino médio com graves problemas de defasagem em matemática para a série correspondente. Assumimos as turmas no segundo semestre devido a atrasos no cronograma do concurso público, e então os alunos tiveram no primeiro bimestre, um professor de Filosofia, que segundo seu próprio relato e confirmado pelos alunos, aplicou textos e trabalhos de sua própria disciplina e também de Sociologia nas aulas destinadas à matemática. Já no segundo bimestre, um professor temporário com contrato do tipo “emergencial”, possuindo graduação em engenharia elétrica, sem nunca antes ter regido qualquer turma assumiu as aulas, passando por inúmeras dificuldades que constam registradas em seu diário como ocorrências disciplinares, bem como uma reprovação no bimestre, isto é, notas abaixo da marca 5,0 de $80 \%$ das três turmas, em contraste com a aprovação de $100 \%$ com notas que variaram de 8,0 a 10 pelo professor de Filosofia.

Estas situações refletiram em um desânimo que tivemos que lidar quando assumimos, já que os alunos no início das aulas não estavam dispostos a realizar tarefas, trabalhos, pesquisas e até mesmo os exercícios em sala de aula. Foi uma adaptação que perdurou por semanas, com algumas aulas destinadas simplesmente a conversas sérias sobre seu aprendizado, sobre sua situação escolar e seus próprios currículos que estavam tão comprometidos até ali, para que enxergassem uma nova atitude por parte do corpo docente e do ensino do Estado, gerando o compromisso por parte deles.

\subsection{2 - Desenvolvimento e os testes}

Para aplicar este estudo foram alvos dos testes todos os 88 alunos das três turmas de $2^{\circ}$ ano, que efetivamente cursavam o ano letivo, observados como um único grupo, sem divisão por classe. 
A aplicação do pré-teste, o questionário para o levantamento das possíveis tendências, foi feita em um primeiro momento, quando o tópico de probabilidade seria iniciado. $\mathrm{O}$ bimestre teve início com o novo assunto de Probabilidade, com duas aulas preliminares expondo os conceitos básicos da teoria: evento, espaço amostral e por fim a forma quantitativa da razão dos casos favoráveis pelos casos possíveis de um evento ocorrer (em espaços equiprováveis). A esses conceitos foi efetuada uma breve prática em sala de aula, com alguns exercícios e discussões.

Após as duas aulas introdutórias, foi aplicado o questionário, composto por 8 questões, sendo que em cada questão o aluno foi instado a estimar um valor de probabilidade diante de um cenário (na maioria das vezes incompleto), e em seguida tendo que colocar a sua justificativa para o valor dado, para serem utilizadas como reforço para os apontamentos do mapeamento das heurísticas e vieses.

O tempo de aplicação dos testes e das atividades seguiu o seguinte cronograma:

\section{$\underline{1^{\circ} \text { Momento: Sondagem }}$}

$1^{\text {a }}$ Semana: 2 aulas preliminares, 2 aulas de aplicação do questionário pré-teste.

\section{$\underline{2^{\circ}}$ Momento: Atividades Propostas}

$2^{\text {a }}$ Semana: Aulas com início da abordagem e aplicação das atividades.

$3^{\text {a }}$ Semana: Aulas com abordagem de probabilidade frequentista.

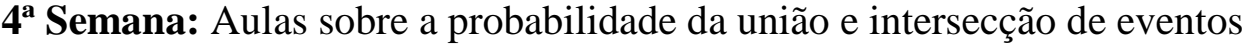

$5^{a}$ Semana: Atividade mensal para efeito de avaliação e aprendizagem sobre as discussões

$6^{\text {a }}$ Semana: Aulas sobre a probabilidade de eventos independentes e probabilidade condicional

\section{$\underline{3^{\circ} \text { Momento: Avaliação das Propostas }}$}

$7^{\text {a }}$ Semana: Atividade para efeito de avaliação e aprendizagem sobre as discussões da correção; revisão do conteúdo e aplicação da primeira questão do pós-teste. 
$8^{a}$ Semana: Aplicação da avaliação bimestral contendo mais duas questões do pós-teste.

Em suma, houve praticamente dois meses de intervalo de tempo entre o pré-teste para o pós-teste, intervalo utilizado para o aprendizado que procurou a melhor forma de aplicar as atividades indicadas pelo levantamento inicial. No próximo capítulo serão detalhadas as fases do projeto, com a descrição e efeitos da sondagem e das atividades, bem como seus resultados. 


\section{Capítulo 3 - Fases do Projeto}

\section{1 - A Sondagem}

Neste primeiro momento do estudo, foi realizada uma sondagem das heurísticas e vieses, bem como os erros de raciocínio estatístico através da aplicação do questionário descrito no capítulo anterior. A aplicação do questionário foi efetuada nas três turmas, após as duas aulas preliminares sobre a teoria das probabilidades, conforme descrito anteriormente. Nestas aulas tivemos apenas exercícios simples, dando espaço para a aula da aplicação que seria a próxima.

\subsection{1 - Aplicação do questionário}

O dia da aplicação foi escolhido aproveitando a oportunidade em que tinham aulas duplas, e portanto sem interrupções. Iniciamos retomando uma discussão sobre as abordagens da teoria das probabilidades, como a probabilidade subjetiva, frequentista ou estatística e a clássica ou equiprovável. Assim que encerramos as observações, o questionário que teriam que responder foi anunciado, e tranquilamente iniciadas as orientações, principalmente a de não se identificarem, pois se tratava de um experimento para verificar no início do curso e ao final, suas respostas e interpretações sobre a probabilidade, embora não caso a caso (para evitar constrangimento) e sim grupo "antes" e "depois". Nessas condições, os alunos se prontificaram a respondê-lo.

As três turmas totalizaram 88 alunos, que receberam o questionário um pouco surpresos de início, achando que se tratasse de alguma atividade ou trabalho surpresa para nota, mesmo tendo sido alertados a não colocarem nenhum tipo de identificação, nem ao menos a da turma. Assim que todos receberam, foi iniciada a leitura para todos da sala, solicitando que aguardassem para as dúvidas gerais.

Ao fim da leitura foi informado que as probabilidades teriam que ser estimadas deliberadamente, de acordo com suas avaliações individuais dos problemas, sem nenhuma preocupação em "acertar" as questões, e que, principalmente teriam que fornecer as 
justificativas para cada valor fornecido, o que gerou certo burburinho durante alguns minutos, até que se acalmassem e iniciassem a tarefa. Importante frisar que este tipo de comportamento e as dúvidas a serem descritas na próxima seção foram similares nas três turmas da aplicação do questionário.

\subsection{2 - Aspectos do Conhecimento no Questionário}

As dúvidas nas respostas do questionário variaram significativamente de acordo com a estrutura das questões. Por exemplo, as questões que possuíam vários itens que necessitavam estimativas para cada item geraram as maiores dúvidas e tomaram a maior parte do tempo para as estimativas. Na tabela a seguir, destacamos as principais dúvidas acerca dos enunciados e as discussões geradas:

\begin{tabular}{|c|c|}
\hline Enunciado das questões & A aplicação \\
\hline $\begin{array}{l}\text { 1. Estimar a chance de Carlos exercer cada } \\
\text { profissão (vendedor, fazendeiro, etc), dados os } \\
\text { estereótipos. }\end{array}$ & $\begin{array}{l}\text { - Muitas dúvidas pela grande maioria dos alunos, pois } \\
\text { pensaram que tinham que optar por uma profissão } \\
\text { apenas, e ainda, colocar simplesmente a probabilidade } \\
\text { sem justificativas. } \\
\text { - Questionamento sobre como estimar a probabilidade, } \\
\text { ou ainda, como justificar uma probabilidade ou chance } \\
\text { de Carlos ser vendedor, ou advogado, pois segundo } \\
\text { sua principal preocupação era a de que não havia } \\
\text { dados para se colocar um valor. } \\
\text { Outras profissões geraram dúvidas pelo seu } \\
\text { desconhecimento, como a profissão de físico, e logo } \\
\text { tratei de explicar resumidamente para que dessem } \\
\text { prosseguimento às respostas. }\end{array}$ \\
\hline
\end{tabular}




\begin{tabular}{|c|c|}
\hline $\begin{array}{l}\text { 2. Fornecer uma estimativa de probabilidade da } \\
\text { moeda ser honesta em cada caso de sequências de } \\
\text { resultados }[(\mathrm{C}, \mathrm{K}, \mathrm{C}, \mathrm{K}, \mathrm{K}, \mathrm{C}),(\mathrm{C}, \mathrm{C}, \mathrm{C}, \mathrm{K}, \mathrm{K}, \mathrm{K}) \mathrm{e} \\
(\mathrm{C}, \mathrm{C}, \mathrm{C}, \mathrm{C}, \mathrm{K}, \mathrm{C})] \text {. }\end{array}$ & $\begin{array}{l}\text { - Questionaram se poderiam fazer uma escolha por um } \\
\text { tipo de sequência, e logo tratei de mencionar que era } \\
\text { semelhante às estimativas do caso da questão } 1 . \\
\text { - O termo "honestidade" gerou muita indecisão, já que a } \\
\text { dúvida principal era sobre a impossibilidade de saber } \\
\text { sem ter uma moeda para lançar; em que tive que } \\
\text { reforçar a leitura do enunciado para que entendessem e } \\
\text { dessem prosseguimento. } \\
\text { - Muitos perguntaram como fornecer uma probabilidade } \\
\text { ou, como extrair este valor, tal era a insegurança dos } \\
\text { alunos nas respostas. }\end{array}$ \\
\hline $\begin{array}{l}\text { 3. Qual a face mais provável a sair no próximo } \\
\text { lançamento em cada sequência abaixo? } \\
{[(\mathrm{C}, \mathrm{K}, \mathrm{C}, \mathrm{K}, \mathrm{K}, \mathrm{C}),(\mathrm{C}, \mathrm{C}, \mathrm{C}, \mathrm{K}, \mathrm{K}, \mathrm{K}) \mathrm{e}} \\
(\mathrm{C}, \mathrm{C}, \mathrm{C}, \mathrm{C}, \mathrm{K}, \mathrm{C})] \text {. }\end{array}$ & $\begin{array}{l}\text { - Muita dificuldade com o fato de "prever" o próximo } \\
\text { resultado. } \\
\text { - Dos } 88 \text { só } 46 \text { responderam à questão, sendo que o } \\
\text { restante ou deixou em branco ou respondeu de forma } \\
\text { igual à } 2^{\mathrm{a}} \text { questão. }\end{array}$ \\
\hline $\begin{array}{l}\text { 4. Estimar a probabilidade de que uma loja tenha } \\
\text { o mesmo resultado no segundo semestre. }\end{array}$ & $\begin{array}{l}\text { - Dúvidas como: “Qual o tipo de loja?” ou “Como é o } \\
\text { final do ano, sempre vendem mais?” Intervenções para } \\
\text { o aluno se ater às condições do problema de forma } \\
\text { mais imparcial possível foram necessárias. }\end{array}$ \\
\hline $\begin{array}{l}\text { 5. Estimar a probabilidade de um ex-detento ser } \\
\text { reincidente. }\end{array}$ & $\begin{array}{l}\text { - Não surtiu dúvidas nas três turmas, alunos } \\
\text { demonstraram certa autonomia na questão. } \\
\text { - Alguns alunos mostraram suas respostas com certa } \\
\text { convicção revelando respostas extremas, como serem a } \\
\text { favor da pena de morte, ou que acreditavam existir um } \\
\text { perfil criminoso, ou seja, que não há reabilitação de } \\
\text { criminosos. As intervenções foram feitas orientando-os } \\
\text { que suas respostas careciam de uma medida, isto é, que } \\
\text { ela transformasse esta convicção de aplicação da "pena } \\
\text { de morte", em um número que transmitisse esta } \\
\text { opinião sobre o tema. }\end{array}$ \\
\hline $\begin{array}{l}\text { 6. Um fabricante de TV fornece garantia de } 1 \\
\text { ano. Qual é, em sua opinião, a probabilidade de } \\
\text { uma TV desta marca quebrar um mês após o } \\
\text { término da garantia? Justifique sua estimativa. }\end{array}$ & $\begin{array}{l}\text { - Não surtiu dúvidas, com os alunos fornecendo as } \\
\text { estimativas de quebra dos televisores demonstrando } \\
\text { certa intimidade e confiança, respondendo em voz alta } \\
\text { para que eu vislumbrasse suas justificativas. }\end{array}$ \\
\hline
\end{tabular}




\begin{tabular}{|c|c|c|c|c|}
\hline \multicolumn{4}{|c|}{$\begin{array}{l}\text { 7. Estimar a nota para um quinto estudante } \\
\text { sorteado, dado que a média do colégio é } \\
\text { conhecida, bem como as quatro notas anteriores. }\end{array}$} & $\begin{array}{l}\text { - Muitas dúvidas quanto à resposta, pois não sabiam se } \\
\text { calculavam, já que não entenderam como estimar a } \\
\text { próxima média. As turmas ficaram divididas quanto a } \\
\text { calcular ou fornecer simplesmente um número. A } \\
\text { intervenção foi no sentido de procurarem o caminho } \\
\text { ou resposta que mais achavam adequado, já que o } \\
\text { professor não podia comprometer e induzir ao } \\
\text { resultado. }\end{array}$ \\
\hline \multicolumn{4}{|c|}{ 8. Dada a distribuição dos alunos: } & \multirow{7}{*}{$\begin{array}{l}\text { - Apesar da tabela de dupla entrada fornecida ser um } \\
\text { tipo de tabela em que, de acordo com os comentários } \\
\text { dos próprios alunos nunca dantes terem tido contato, } \\
\text { não os impediu de responder rapidamente à questão. } \\
\text { - Única dúvida que surgiu foi quanto ao item c), em que } \\
\text { muitos disseram que se tratava de uma questão } \\
\text { idêntica ao item B, por desconhecerem os termos sutis } \\
\text { que distinguem a probabilidade da união de eventos da } \\
\text { probabilidade condicional, e rapidamente os orientei a } \\
\text { responderem conforme haviam entendido, mesmo que } \\
\text { achassem que eram idênticas. }\end{array}$} \\
\hline \multirow{2}{*}{ Gênero } & \multicolumn{2}{|c|}{ Gosta de Esporte } & \multirow{2}{*}{ Total } & \\
\hline & Sim & Não & & \\
\hline M & 50 & 10 & 60 & \\
\hline $\mathrm{F}$ & 30 & 10 & 40 & \\
\hline Total & 80 & 20 & 100 & \\
\hline \multicolumn{4}{|c|}{$\begin{array}{l}\text { Fornecer a probabilidade de que um aluno } \\
\text { escolhido seja do gênero } \mathrm{M} \text { e goste de esporte? } \\
\text { Probabilidade que seja masculino ou goste de } \\
\text { esporte e que goste de esporte, sabendo que é do } \\
\text { gênero masculino. }\end{array}$} & \\
\hline
\end{tabular}

Quadro 2: Aplicação do Questionário de Sondagem - aspectos do conhecimento

Verificamos que as questões que continham mais de um item (descrição no Quadro 2) tomaram mais tempo para as respostas e surtiram mais dúvidas no geral.

Nas questões 1, 2 e 3 que possuíam vários itens solicitando uma estimação de probabilidade em cada caso, uma sugestão que possivelmente poderia atenuar as dúvidas e tornar mais dinâmico o preenchimento, seria substituir os itens inserindo-os numa tabela, deixando espaços para o preenchimento das probabilidades e o espaço reservado para a justificativa, solicitando que "completassem" a tabela, o que tornaria a tarefa mais simples. Este tipo de estrutura para a questão seria essencial, por exemplo, para a questão 3, que conforme a descrição anterior foi prontamente confundida com a questão 2, não só pela dificuldade com o enunciado, mas sim, pela necessidade de se fornecer além da probabilidade e justificativa, o próximo resultado.

No geral, as questões que surtiram maior número de dúvidas e insegurança ao estimar a probabilidade foram as questões mais abstratas, que fugiam do contexto ou que não possuíam respaldo na vivência dos alunos, como as do lançamento das moedas (questões 2 e 
3). Apesar da questão 1 (profissões possíveis de Carlos) ter demandado muito tempo pelo número de itens, suas respostas foram rápidas para as estimativas. Para as outras questões, (excetuando a questão 7 da estimação da média) cujo meio favoreceu suas respostas, as estimativas foram dadas prontamente, em que os alunos demonstraram pouca indecisão, mostrando em certos casos muita segurança em suas afirmações.

Outra sugestão que talvez ajudaria(a ser verificada em outra oportunidade) seria a realização do experimento em duplas, já que não havia necessidade de identificação e as turmas se configuraram como um grande grupo. Como descrito na Tabela 1 e mais detalhadamente na análise dos resultados, os alunos tiveram um grande desconforto em estimar valores tidos como livres, tornando-os inseguros, e por consequência inquietos e tornando a interromper frequentemente os colegas em busca de pistas, que poderiam, se em duplas, atenuar esta insegurança.

A análise das respostas coletadas será o próximo passo para verificarmos a existência ou não das heurísticas, vieses e erros de raciocínio, de acordo com suas estimativas e justificativas.

\subsection{3 - Análise das Respostas}

O levantamento realizado sobre as respostas dadas ao questionário procurou estabelecer uma relação entre a "resposta esperada", isto é, a resposta a uma questão em que não há informações suficientes ou mesmo qualquer informação relevante para o cálculo ou estimativa de uma probabilidade, e a resposta apresentada pelos alunos procurando revelar as tendências e vieses no julgamento sob incerteza, bem como seus erros de raciocínio estatístico; e ainda, procurar pontos onde existam indícios facilitadores do ensino de probabilidade, ou seja, possíveis pontos de vista razoáveis que possam ajudar na forma de conduzir a disciplina, bem como ilustrar através de exemplos que sigam estes pontos .

As respostas e os resultados estão enumerados na mesma ordem com que foram dadas as questões anteriormente, e dentre várias possibilidades de análise, optou-se por fazer, como já mencionado, uma análise descritiva das respostas dos alunos, através de medidas-resumo (posição e variabilidade) e de gráficos (boxplots - para os valores estimados, ou gráficos de setores - para as justificativas). 
A escolha pelo boxplot é a facilidade visual para a observação de algumas estatísticas, como por exemplo, a mediana (valor central dos dados ordenados) ou o $3^{\circ}$ Quartil (valor que separa $75 \%$ dos valores inferiores a ele dos demais). Foi informado também o número (n) de respondentes em cada caso. Ao final de cada análise, apresentamos um resumo das conclusões para cada questão. Gráficos e medidas descritivas foram obtidos por meio do aplicativo R (Crawley, 2007).

\section{Questão 1:}

Esta questão, como foi a primeira apresentada, causou algum desconforto aos alunos, que passaremos a descrever. Havia uma solicitação de uma estimativa da probabilidade do personagem exercer cada profissão e, além das dúvidas citadas anteriormente sobre o preenchimento - tratava-se de escolher apenas uma ou fornecer um valor para cada. Os alunos, conforme seus comentários ao longo do preenchimento, mostravam-se preocupados em acertar as questões, isto é, fornecer um valor que em suas concepções fosse o "verdadeiro" procurado, ou solicitado pelo questionário, e nesta busca, a ansiedade foi aumentando conforme seguiam respondendo, e ainda, se mostrando cada vez mais insatisfeitos com o professor, por ter aplicado questões que conforme disseram, não tinham como ser respondidas por não terem ainda aprendido o conteúdo, e pelo fato de o problema não trazer os valores.

Os alunos mostraram com estas atitudes que estavam à procura de um número, de uma certeza matemática, de um determinismo que não cabia à tarefa; mesmo sendo alertados de que não se tratava de um trabalho ou atividade para nota, o simples fato de fornecer uma estimação causou muito desconforto nos alunos das três turmas; o simples fato do problema não conter valores, números, ou informações relevantes desencadeou este comportamento nas turmas e, logo de início, observamos que os alunos não conseguiam construir um cenário coerente para suas respostas e, neste processo, procuraram tirar conclusões precipitadas frente à informação escassa.

$\mathrm{O}$ viés de representatividade (informações no enunciado) já se mostrava evidente. $\mathrm{E}$ de fato, quando alguns alunos começaram a dizer em voz alta para o restante da turma seus julgamentos e escolhas, mostraram já de início a predileção pela profissão de físico e a predisposição de rejeitar a de vendedor. Tivemos nestes momentos que intervir pedindo colaboração, para evitar qualquer influência nos demais. 
Analisando as probabilidades fornecidas pelos respondentes ( $\mathrm{n}=88$ alunos), onde não houve respostas em branco, construímos a Tabela 1 com as estatísticas descritivas e um gráfico do tipo boxplot (Figura 1). Poderíamos esperar para esta questão a resposta "não há informações suficientes para fornecer uma resposta", ou mesmo uma estimativa conservadora de 0,50 , diante do cenário com pouca informação.

Tabela 1: Medidas descritivas das estimativas para probabilidades

\begin{tabular}{c|c|c|c|c|c}
\hline Profissão & $\mathbf{n}$ & Mediana & Média & $\boldsymbol{Q}_{\mathbf{3}}$ & $\begin{array}{c}\text { Desvio } \\
\text { Padrão }\end{array}$ \\
\hline Vendedor & 88 & 0,25 & 0,30 & 0,40 & 0,24 \\
\hline Advogado & 88 & 0,40 & 0,42 & 0,65 & 0,29 \\
\hline Engenheiro & 88 & 0,60 & 0,57 & 0,80 & 0,30 \\
\hline Fazendeiro & 88 & 0,60 & 0,56 & 0,80 & 0,30 \\
\hline Físico & 88 & 0,60 & 0,58 & 0,85 & 0,31 \\
\hline
\end{tabular}

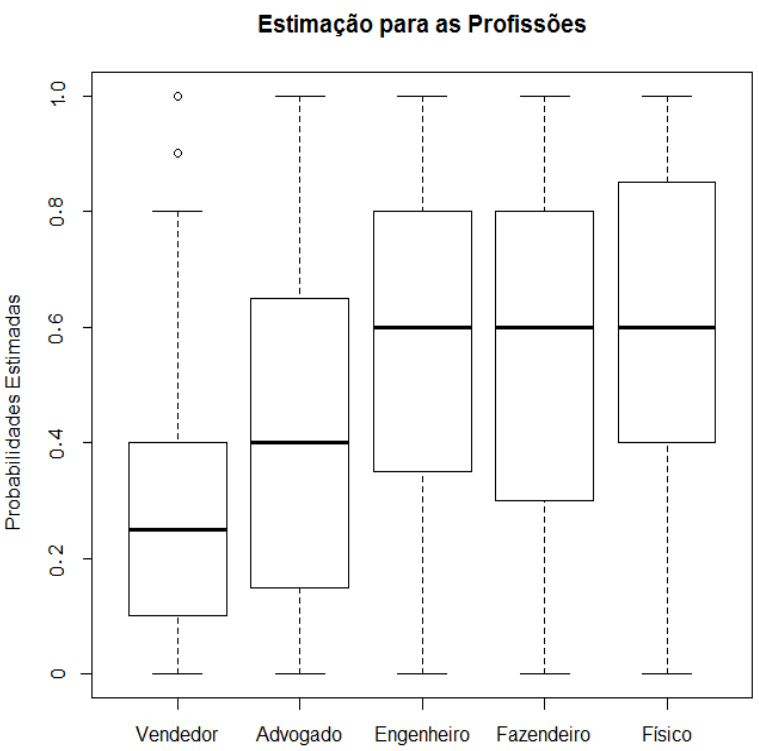

Figura 1: Panorama conjunto das estimativas para probabilidades

Como já foi dito, além da estimativa pedida, era solicitada uma justificativa para o valor dado. Para esta questão, dos 88 respondentes, mais de $80 \%$ do total dos alunos justificaram as estimativas, refletindo pouca dificuldade para essa tarefa escrita, nesta questão.

Tanto a Tabela 1 como a Figura 1 mostram a "preferência" pelas opções Físico, Fazendeiro e Engenheiro, em detrimento das outras duas (advogado e vendedor).

A mediana de 0,25 para vendedor nos informa que metade dos respondentes estimou uma probabilidade no máximo igual a este valor para identificar o perfil como vendedor - ou seja, as características apresentadas afetaram a decisão: o perfil não se coaduna com vendedor (nem muito com advogado, que apresentou mediana de 0,40). As estimativas para vendedor estão mais concentradas do que as demais (menor desvio padrão), e percebe-se que $75 \%$ dos respondentes estimaram a probabilidade de ser vendedor como no máximo 0,4 (40\%).

Observa-se a grande variabilidade nas respostas, com todos os valores entre 0 e 1 representados em todas as profissões, refletindo os valores altos de desvio padrão. Os comentários nos gráficos de setores apresentados na Figura 2 dão a informação das opiniões 
dos alunos sobre suas estimativas de probabilidades para advogado e vendedor (analisadas as respostas dos alunos no Intervalo Interquartil - ou seja, $50 \%$ dos respondentes entre o $1^{\circ}$ e o $3^{\circ}$ Quartis). Observa-se a grande maioria identificando as características "tímido e retraído" como responsáveis pelas respostas.

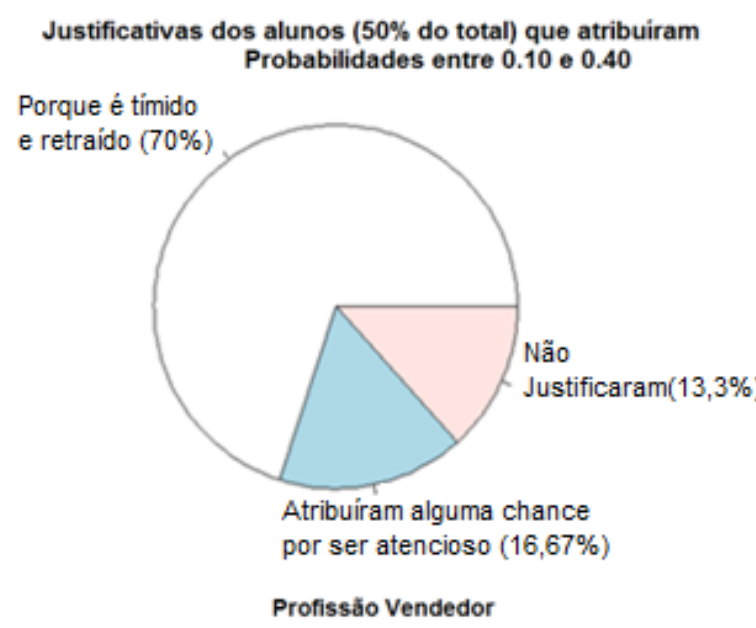

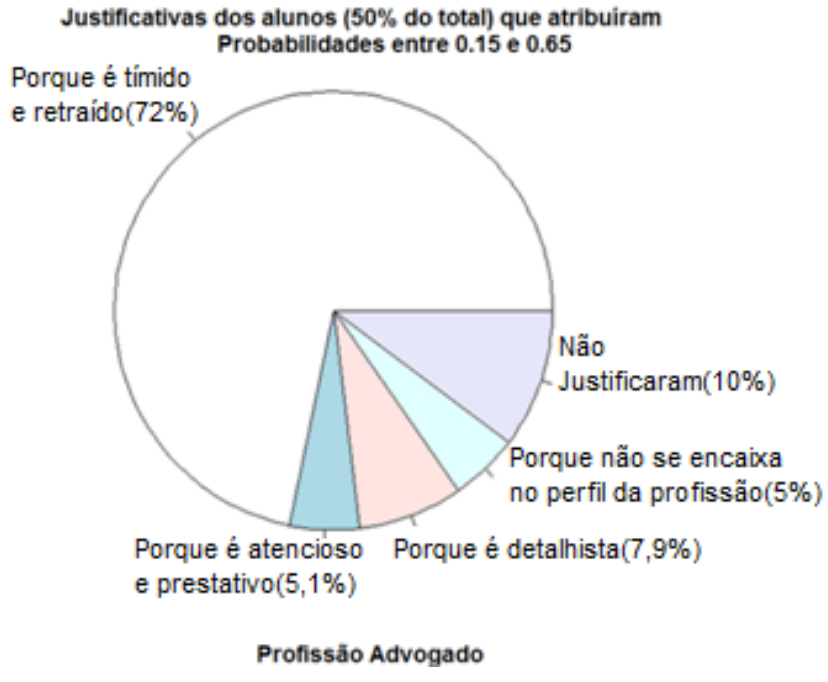

Figura 2: Gráficos com justificativas para Vendedor/ Advogado para probabilidades no IQ (50\%, n=44) por estas profissões em relação às de vendedor ou advogado, pelas características descritas.

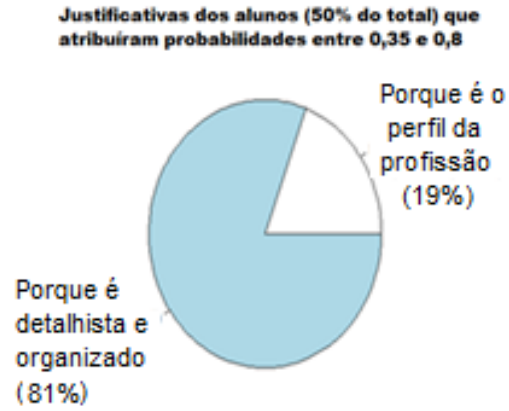

Profissăo Engenheiro

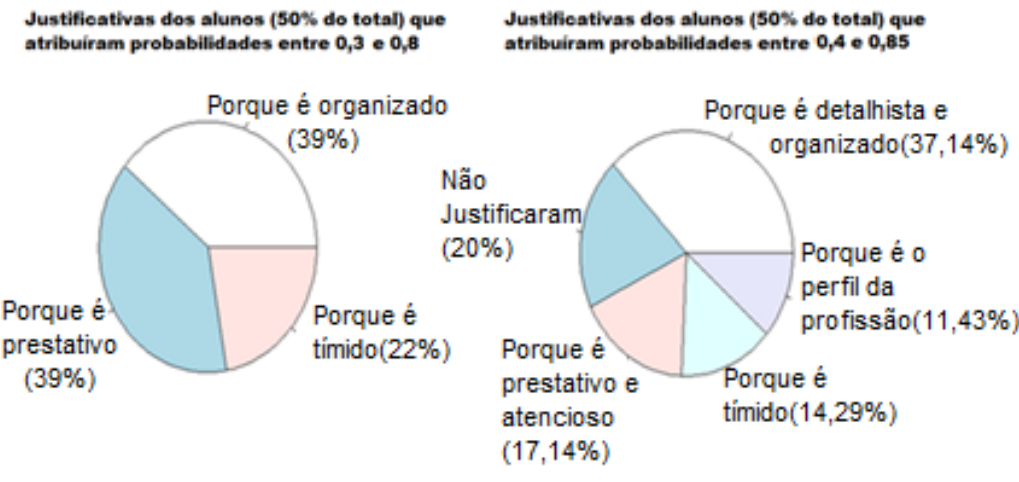

Profissào Fazendeiro
Profissào Fisico

Figura 3: Justificativas para as profissões de fazendeiro, engenheiro e físico no IQ ( $50 \%, n=44)$ 
Os poucos alunos (acima do $3^{\circ}$ Quartil) que acharam mais provável a profissão de vendedor mencionaram que consideram fundamental para ser vendedor a característica: "detalhista e atencioso"; da mesma forma que na profissão de advogado, em que estes estereótipos os levaram a considerar maior probabilidade de exercer estas profissões.

Resumindo, para a profissão de vendedor, a estimação de probabilidade apresentou mediana de 0,25 e conforme o boxplot da Figura 1,75\% dos alunos estimaram chances de no máximo 0,40, ou seja, atribuíram pouca chance de Carlos exercer esta profissão, mostrando uma forte assimetria na distribuição dos julgamentos, pendendo para probabilidades mais baixas. Este resultado mostra forte influência das características atribuídas, onde a característica de Carlos ser tímido e retraído levou-os a enxergarem como pouco similar à profissão de vendedor, o que foi reforçado pelas justificativas dos alunos que estimaram os valores até o terceiro quartil.

A profissão de advogado apresentou tendência para probabilidades um pouco mais altas, com mediana 0,40, embora a característica de ser tímido e retraído, da mesma forma que na profissão anterior, teve um papel importante.

Pelos resultados percebe-se que os alunos identificaram o perfil de Carlos mais para as profissões de Engenheiro, Fazendeiro ou Físico, embora em todos os casos, observa-se, como já dito, estimativas de 0 a $1(0 \%$ a $100 \%)$.

Observamos assim forte evidência da heurística de representatividade e, conforme supusemos inicialmente, as tendências mostram este forte viés, já que respostas sem viés seriam aquelas que não apresentassem qualquer justificativa pelos estereótipos, ou que fossem consideradas as características da população da cidade de São Paulo (grande quantidade de vendedores), da realidade dos alunos, ou ainda, que mostrassem conservadorismo nas estimativas (probabilidades em torno de 0,50). Assim, tanto o comportamento dos alunos como suas justificativas reforçaram o viés.

\section{Questões 2 e 3:}

Nestas questões foram solicitadas estimativas de probabilidade de uma moeda ser honesta para cada caso de sequências de resultados $[(\mathrm{C}, \mathrm{K}, \mathrm{C}, \mathrm{K}, \mathrm{K}, \mathrm{C}),(\mathrm{C}, \mathrm{C}, \mathrm{C}, \mathrm{K}, \mathrm{K}, \mathrm{K})$ e $(\mathrm{C}, \mathrm{C}, \mathrm{C}, \mathrm{C}, \mathrm{K}, \mathrm{C})]$ e em seguida, qual a face mais provável a sair em um hipotético próximo lançamento em cada caso. 
A resposta esperada seria "a chance é a mesma" para qualquer sequência, dadas as curtas sequências de resultados; ou ainda "Não se pode saber sobre a honestidade com poucos resultados" ou por fim uma contagem dos resultados pelos alunos. No caso da próxima face, o esperado seria que "não há preferência para a próxima face", já que sequências curtas de resultados não deveriam influenciar o julgamento.

O levantamento das respostas revelou que os julgamentos, bem como as justificativas foram afetados pelo tipo da sequência apresentada, ou pelo histórico das sequências, como no gráfico da Figura 4, na qual temos de forma ordenada pelas medianas, em ordem crescente da considerada menos honesta até a considerada mais honesta.

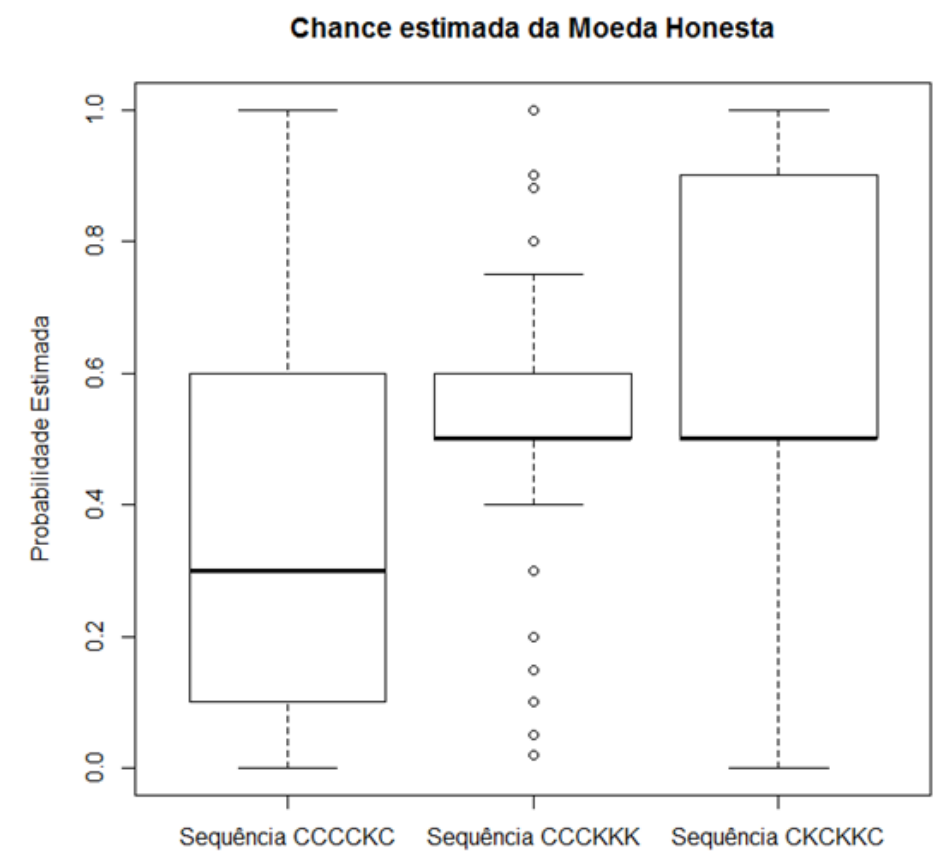

Figura 4: Probabilidades estimadas para os três tipos de sequências do lançamento de moedas $(n=88)$.

As estatísticas descritivas que constam na Tabela 2 se referem aos alunos respondentes com relação à honestidade da moeda, com o respectivo número (n) em cada sequência, já que houve alunos que responderam que não entenderam a questão e ainda, respondendo de forma incorreta escolhendo apenas uma sequência como alternativa.

Tabela 2: Medidas descritivas das estimativas para as probabilidades em cada tipo de sequência.

\begin{tabular}{l|c|c|c|c|c|c}
\hline & \multicolumn{6}{|c}{ Estatísticas Descritivas } \\
\hline Sequência & $\mathbf{n}$ & $\boldsymbol{Q}_{\mathbf{1}}$ & Mediana & Média & $\boldsymbol{Q}_{\mathbf{3}}$ & Desvio Padrão \\
\hline CCCCKC & 80 & 0,10 & 0,30 & 0,39 & 0,60 & 0,31 \\
\hline CCCKKK & 79 & 0,50 & 0,50 & 0,52 & 0,60 & 0,25 \\
\hline CKCKKC & 75 & 0,50 & 0,50 & 0,64 & 0,90 & 0,24 \\
\hline
\end{tabular}


Analisando as medianas, vemos uma predileção para as sequências CCCKKK e CKCKKC com tendência a julgar em 0,50 a chance de ser honesta, enquanto que na sequência CCCCKC julgaram como baixa, 0,30 a probabilidade desta moeda ser honesta, conforme o boxplot na Figura 4.

Os valores das tendências dos julgamentos de probabilidades, como na sequência CCCCKC conforme a Figura 5, considerada como a menos provável para ser honesta, teve como justificativas que "A moeda não está equilibrada", ou "a maioria foi de caras", e assim por diante, revelando que o julgamento pela honestidade da moeda se deu pelo formato da sequência de resultados, e após simples contagem dos resultados inclinaram-se por este julgamento por ter saído apenas um resultado K.

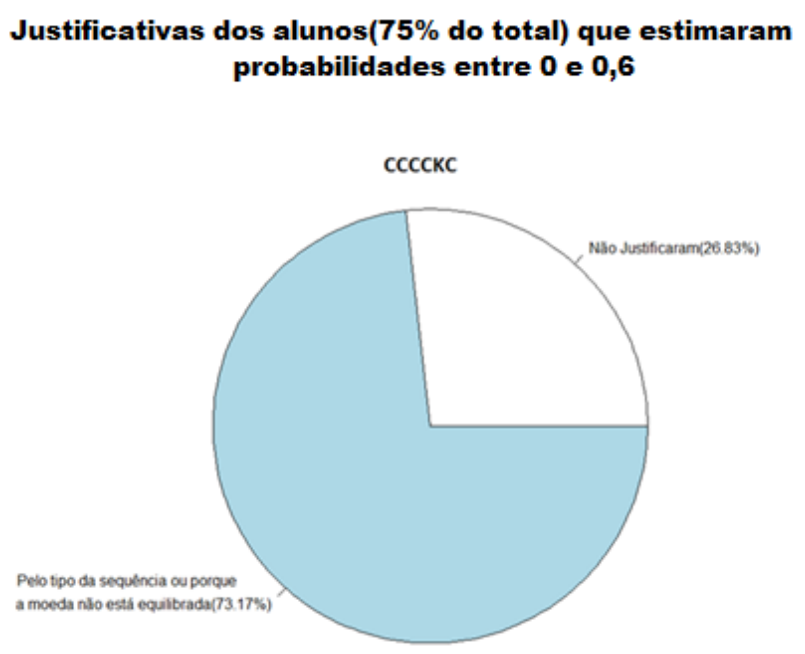

Figura 5: Justificativas para a sequência CCCCKC (n=66)

As justificativas das outras duas sequências foram similares, como no caso da sequência da Figura 6 (CCCKKK), em que o equilíbrio numérico dos resultados de C e K os levou a julgar como maior a probabilidade de serem honestas, com 56\% dos alunos observando que "a sequência está equilibrada". Um grupo de 17\% dos alunos chamou a atenção pela resposta de não haver possibilidade de prever a honestidade da moeda, com estimativa em torno da mediana, revelando uma postura conservadora, ainda que levados pelo formato das sequências. 


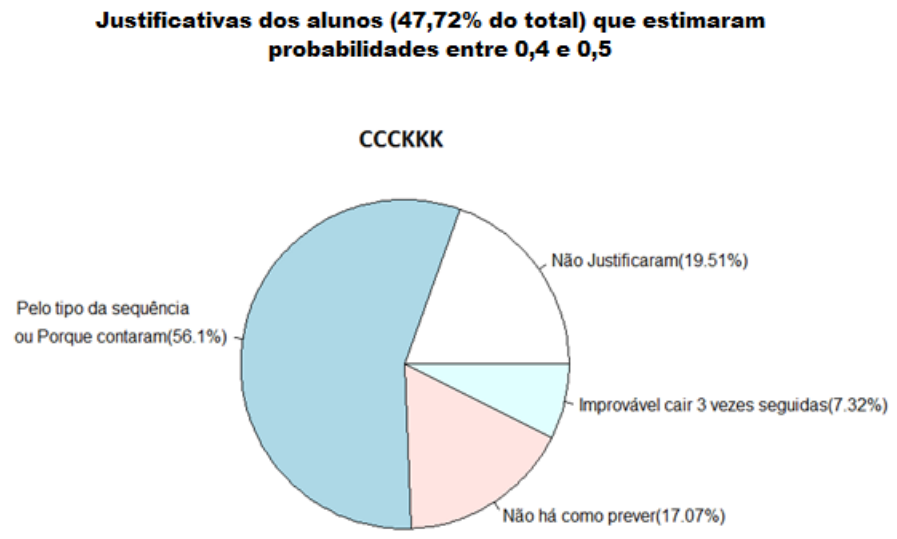

Figura 6: Justificativas para a sequência CCCKKK $(\mathrm{n}=42)$

Através da Figura 4 pode ser observado que os alunos respondentes indicaram a sequência CKCKKC como a que tem maior probabilidade de ser honesta em relação às demais (50\% dos resultados entre 0,5 e 0,9), sendo que a sequência CCCKKK tem a mesma mediana mas apresenta $50 \%$ dos resultados entre 0,5 e 0,6. As justificativas apresentadas remetem ao viés de julgamento pelo formato das sequências: "Porque está equilibrada"; ou "Por saírem consecutivamente C e K", "Porque é a mais ocasional"; e ainda, "Porque tem o mesmo número de $\mathrm{C}$ e $\mathrm{K}$ ". Lembramos que uma das respostas esperadas seria, como já dito à página 60 , "Não se pode saber sobre a honestidade com poucos resultados".

$\mathrm{Na}$ questão 3, ao prever a próxima face da moeda, verificamos o mesmo comportamento no julgamento dos alunos, tanto pelo alto número de não-respostas devidos às mesmas dúvidas da questão 2 (honestidade), quanto pelas tendências apresentadas de acordo com o formato das sequências, o que também foi indicado pelas justificativas.

$\mathrm{Na}$ Tabela $3 \mathrm{com}$ as medidas resumo, em que a estatística de interesse foi a proporção das escolhas por cada face, os resultados indicaram uma escolha pela próxima face que "equilibrasse" os resultados, isto é, por se tratar de uma moeda, e portanto "honesta" ou "equilibrada". Assim, este fator os induziu a julgar sobre a extração de um resultado aleatório, levando a erros sistemáticos que foram encadeando-se por associatividade de ideias.

Tabela 3: Proporções para a próxima face mais provável.

\begin{tabular}{l|c|c|c|c|c}
\hline & \multicolumn{5}{|c}{ Resposta para a próxima face } \\
\hline Sequência & $\mathbf{n}$ & $\boldsymbol{K}$ & Qualquer & $\mathbf{C}$ & Não Resposta \\
\hline CKCKKC & 45 & $21,5 \%$ & $19,5 \%$ & $10 \%$ & $49 \%$ \\
\hline CCCKKK & 50 & $10 \%$ & $20,5 \%$ & $27 \%$ & $42,5 \%$ \\
\hline CCCCKC & 48 & $20,5 \%$ & $11 \%$ & $23 \%$ & $45,5 \%$ \\
\hline
\end{tabular}


Quando a sequência foi praticamente alternada, como na CKCKKC, a escolha tendeu para K com $21 \%$ contra $10 \%$ dos respondentes. Nas sequências CCCKKK e CCCCKC, a opção se inverteu com relação à primeira sequência, julgando pela preferência da próxima face C, por de $27 \%$ contra $10 \%$ e $23 \%$ contra $20 \%$ respectivamente, do total dos alunos para a face K, justificando para ambos os casos que: "os resultados são iguais"; ou "o número de caras e coroas é igual, mas a próxima face seria C, pois saíram três coroas seguidas" como no caso da sequência CCCKKK; estas justificativas revelam a inversão na opção da próxima face, levados novamente pela forma da sequência.

Mesmo no grupo dos alunos que optou por "qualquer face", salvo exatos 5 alunos na sequência CCCCKC que justificaram de acordo com o esperado, isto é, que "a chance para cada é de 50\%, pois é um lançamento" ou que "a chance é $50 \%$ para os dois, pois a moeda tem dois lados" ; todos justificaram a imparcialidade pelo fato dos resultados estarem equilibrados nas outras duas sequências, assim, guiados pelo viés da representatividade.

Uma diferença nestas questões foi observada em relação à primeira questão (das profissões): o percentual de alunos que não justificaram suas estimativas foi maior agora do que na primeira questão, algo que o comportamento já descrito das turmas já indicava no momento da aplicação, mas um outro fator será discutido na seção 3.1.4, nos comentários dos resultados.

Em resumo, o formato das sequências afetou os julgamentos em probabilidade dos alunos, tanto para julgar qual a sequência mais "honesta", quanto à próxima face mais provável, sendo que na sequência com resultados numericamente equilibrados, foram tidas como mais honestas, e a face mais provável escolhida nestes casos se deu em uma tentativa de equilibrar as sequências, novamente corroborando nossas suposições iniciais do viés de representatividade.

\section{Questões 4,5 e 6:}

Nestas questões foi solicitado que estimassem respectivamente, a probabilidade de que uma loja tenha o mesmo resultado no segundo semestre dado um resultado ruim no semestre anterior, a probabilidade de que um ex-detento venha a ser reincidente no Brasil e por último, a probabilidade de quebra de uma TV um mês após o término da garantia. 
Estas questões foram agrupadas dado o viés de Disponibilidade que procuramos verificar em comum a estes tipos de cenários, e que revelaram após a análise dos resultados um padrão que será discutido ao final da seção.

A resposta esperada nestas questões, cujas informações são escassas e apresentam cenários parciais, seria a conservadora, com probabilidade 0,50 para qualquer resultado.

De acordo com a Tabela 4, cujos resultados estão resumidos com as questões por linha, observamos inicialmente o baixo índice de não respostas até então, sendo que todos responderam às questões 5 e 6 , bem como o menor índice de respostas sem justificativas, reafirmando nossos comentários da segurança apresentada pelos alunos durante a aplicação do questionário.

Tabela 4: Estatísticas descritivas para as probabilidades dos resultados.

\begin{tabular}{l|c|c|c|c|c|c}
\hline \multicolumn{1}{c}{ Qstatísticas Descritivas } \\
\hline \multicolumn{1}{c|}{ Questão } & $\mathbf{n}$ & $\boldsymbol{Q}_{\mathbf{1}}$ & Mediana & Média & $\boldsymbol{Q}_{\mathbf{3}}$ & Desvio Padrão \\
\hline 4: Resultado ruim de loja & 69 & 0,50 & 0,50 & 0,55 & 0,65 & 0,19 \\
\hline 5: Reincidência de presos & 88 & 0,50 & 0,74 & 0,71 & 0,90 & 0,17 \\
\hline 6: Quebra de uma TV & 88 & 0,40 & 0,50 & 0,57 & 0,80 & 0,25 \\
\hline
\end{tabular}

A mediana das estimativas das questões da loja e para a quebra de uma TV foi de 0,50, revelando a princípio conservadorismo nos julgamentos. Esta tendência a julgar com o valor de 0,50 foi corroborada nas justificativas destas questões, como no caso da loja na Figura 8, em que $85 \%$ disseram "apesar da loja ter ido mal, poder melhorar no semestre seguinte", bem como no caso da quebra da TV, com fatores implícitos e considerações contrárias ao que o enunciado parcial indicava, como por exemplo "há sempre chance de quebra".

$\mathrm{Na}$ questão da reincidência de presos, apesar do valor de 0,74 da mediana, as justificativas revelaram posturas mais radicais, como considerações do tipo "uma vez criminoso, sempre voltará a cometer crimes"; ou seja, acreditando em um perfil criminoso do indivíduo, algo que se acentuou nas justificativas das probabilidades mais altas. 
Estimação para os eventos

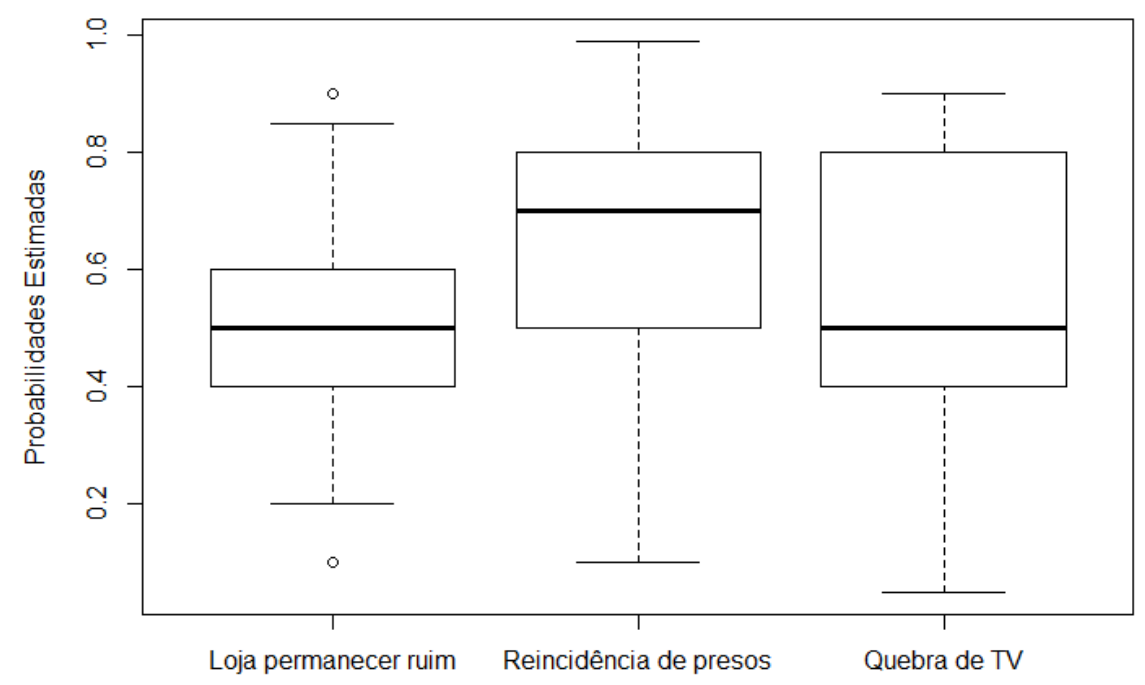

Figura 7: Panorama conjunto dos resultados das estimativas das probabilidades dos eventos.

Nestas três questões, o fato dos alunos terem levado em conta fatores contrários ao que a descrição indicava, fez com que não fossem afetados pelo viés de Disponibilidade pelos exemplos que possivelmente lhes ocorresse, ou seja, não julgaram como nas demais questões de acordo com os exemplos ressaltados quase que diariamente pela mídia, mostrando que acreditaram no fator da incerteza para não tomarem decisões apenas pela descrição dada no problema, conforme a Figura 8 mostra as justificativas para os valores centrais.

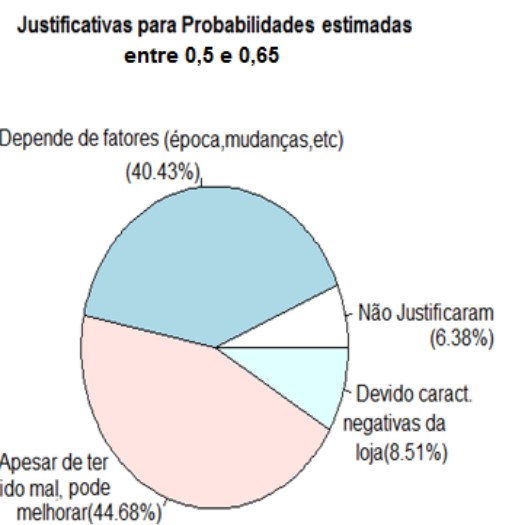

Loja permanecer ruim
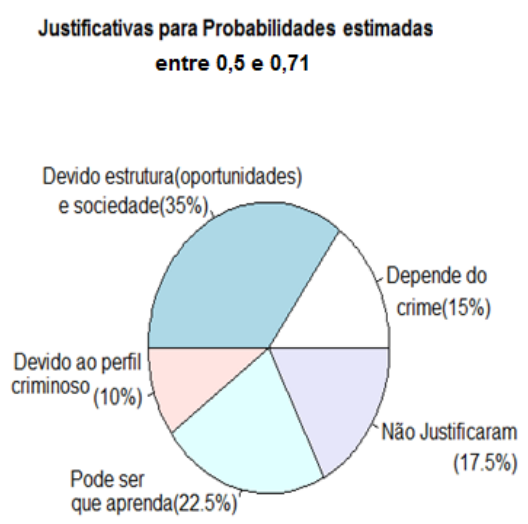

Reincidência de presos
Justificativas para Probabilidades estimadas

entre 0,4 e 0,8

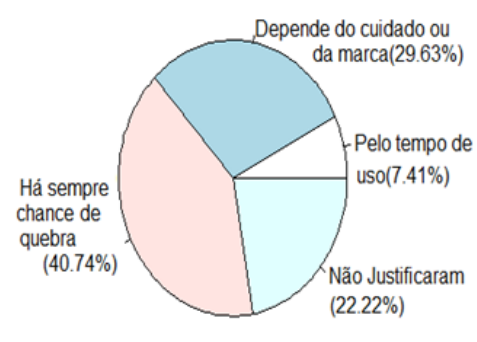

Quebra de uma TV após garantia

Figura 8: Justificativas para as estimativas dos eventos no intervalo interquartil em cada questão. 
Os alunos que julgaram como altas as probabilidades dos eventos para as três questões, estimativas acima do terceiro quartil, justificaram revelando forte influência no cenário dos enunciados, como no caso da descrição medíocre da empresa justificando que, "dado o resultado ruim no primeiro semestre, dificilmente irá melhorar no segundo semestre", exemplificando e extrapolando as descrições como ter "gerentes ruins", "falta de atrativos", etc.

Nestes casos dos alunos acima do terceiro quartil, as descrições induziram a julgamentos não favoráveis, assim como o fato de ser ex-detento, que os levou a citar casos de exemplos de pessoas e ou parentes reincidentes, e assim foi verificado o viés pela lembrança de exemplos, levando a um julgamento precipitado.

Em resumo, metade dos alunos que responderam às questões mostrou o viés de representatividade na insensibilidade à previsibilidade, enquanto que a outra metade se mostrou sensível quanto ao fato das informações serem não confiáveis, ou seja, o grau de previsibilidade foi afetado pela descrição insuficiente.

Estas questões mostraram pela primeira vez uma clara divisão nos julgamentos, revelando um formato de questão que será verificado como parte de um padrão discutido no final do capítulo, por permitir uma diminuição dos vieses, ou seja, por permitir uma resposta sem o viés no julgamento, o que nos mostrará também uma abordagem para o ensino de probabilidade.

\section{Questão 7:}

A sétima questão aborda a ideia do valor esperado para as notas de um colégio, que, a propósito, é fornecido como nota 4,0 (média da escola toda). É dito que um sorteio ao acaso de 5 alunos foi realizado e são fornecidas notas de 4 alunos. Os alunos possuíam um conhecimento básico do cálculo da média aritmética, já tendo trabalhado em sala de aula com este tipo de operação e a pergunta pedia a estimação para o $5^{\circ}$ valor.

A resposta poderia ser o valor esperado das notas do colégio fornecida no enunciado. Ainda, qualquer nota poderia ser dada por se tratar do quinto estudante sorteado, desde que na justificativa se deixasse claro que qualquer nota poderia ser possível. Não houve resposta ou justificativa em branco, fato que a confiança dos alunos ante a questão já indicava 
No gráfico boxplot da Figura 9, a mediana da nota estimada pelos alunos foi de acordo com o valor esperado $(4,0)$, contendo $50 \%$ das estimativas muito próximas à nota esperada.

O comportamento é reforçado pelas estatísticas da Tabela 5, com o baixo valor de desvio padrão, revelando o que a confiança dos alunos já apontava e o que suas justificativas confirmaram, onde destacamos para esta questão em particular, apenas as respostas para a nota esperada, conforme a Figura 9.

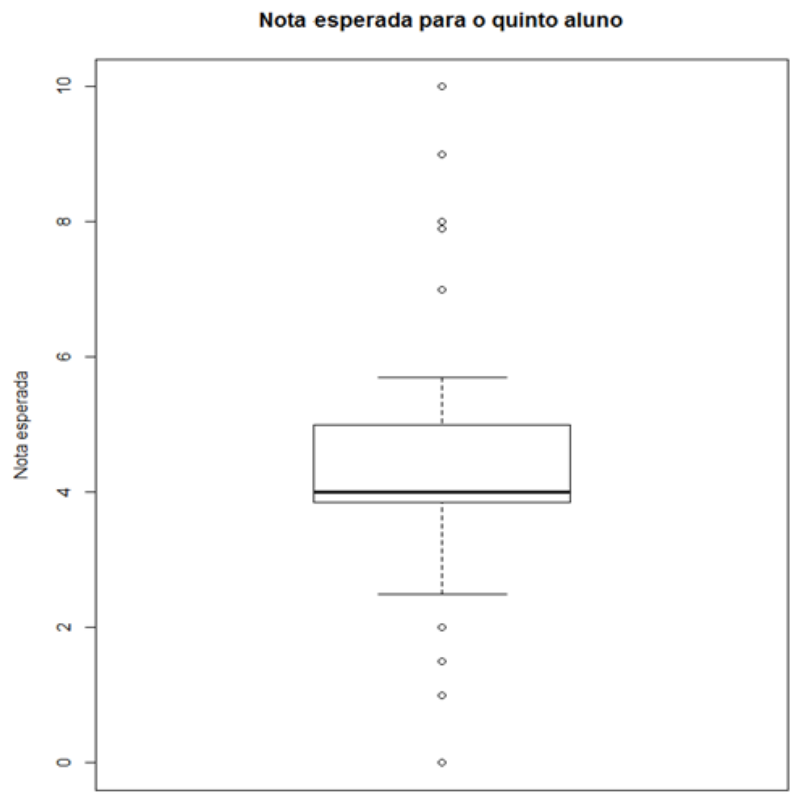

Justificativas para nota esperada 4,0 ( $n=25 ; 22 \%$ dos alunos)

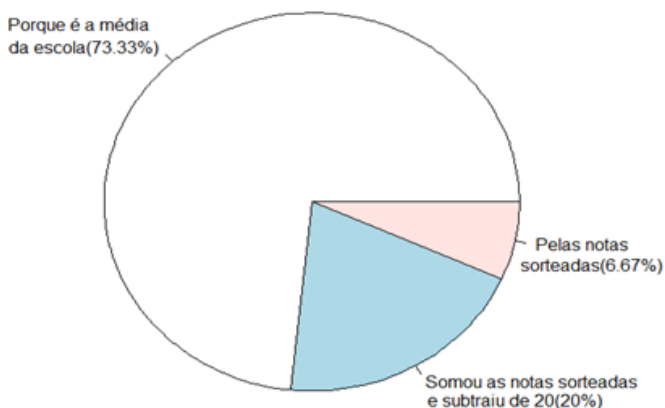

Figura 9: Resultados para as previsões da nota de um aluno sorteado e as justificativas ( $\mathrm{n}=88$ ).

Tabela 5: Estatísticas descritivas para a nota esperada para o quinto aluno sorteado. Estatísticas Descritivas

\begin{tabular}{c|c|c|c|c|c}
\hline $\mathbf{N}$ & $\boldsymbol{Q}_{\mathbf{1}}$ & Mediana & Média & $\boldsymbol{Q}_{\mathbf{3}}$ & Desvio Padrão \\
\hline 88 & 3,85 & 4,0 & 4,5 & 5,0 & 1,96 \\
\hline
\end{tabular}

Ainda neste grupo que estimou a nota 4,0 tivemos 6 alunos no total que não fugiram do caráter computacional citado no artigo de Batanero (1994). De acordo com suas justificativas, ainda que procedendo de forma aceitável diante do cenário ao usar a amostra para calcular a média, tiveram uma extrema preocupação em chegar ao valor 4,0 aproximando 
deliberadamente ao valor, ao contrário de usarem a média amostral 3,95 (calcularam $3,8+4+6+2=15,8$; gerando 3,95 e então ficaram com a nota 4,0 por aproximação).

As notas até o terceiro quartil ( $75 \%$ das notas) não ultrapassaram 5,0, mostrando uma certa ancoragem às notas baixas fornecidas dos 4 primeiros alunos.

Para os alunos acima do terceiro quartil, as justificativas levaram em consideração fatores que não se prendiam às notas fornecidas, como por exemplo: "o aluno pode ser dedicado", ou que "pode ter estudado" - ; enquanto que os alunos que estimaram notas mais baixas do que 4, abaixo do primeiro quartil justificaram baseando-se nas notas fornecidas no sorteio, observando que a nota está de acordo com a sequência.

A conclusão neste caso é que, salvo o grupo que estimou a nota 4 de acordo com a média da nota do colégio, o valor esperado, um total de 18 alunos, houve um erro de entendimento relacional, já que o aluno conhecia o caráter computacional e suas regras para o cálculo de um problema específico, mas não conseguiu relacionar a estimação de uma média, ou estender este conceito de forma generalizada. Ou seja, valor esperado não é um conceito que intuitivamente se relaciona ao valor médio - tem que ser construído.

\section{Questão 8:}

Esta questão apresentava uma tabela de dupla entrada para estimação da probabilidade da união, intersecção e condicional, relacionando gênero e gosto por esporte.

As respostas esperadas seriam os valores $0.5,0.9$ e 0.83 respectivamente para os itens a, b e c. Nenhum aluno deixou em branco a questão, mas dos 88 que responderam, 51 não justificaram os valores estimados, o que refletiu o fato das muitas dúvidas descritas na seção 3.1.1. no momento da aplicação.

De acordo com a Figura 10, e a Tabela 6 podemos observar que a probabilidade mediana em (a) foi de 0,66 (para o esperado 0,5); em (b) a mediana foi de 0,6 (para o esperado de 0,9 ) e, por último, em (c) a mediana foi de 0,6 (para o esperado de 0,83). Os valores dos terceiros quartis, de 0.9 e 0.8 indicaram comportamento de alguns em julgar como altas as probabilidades dadas as características apresentadas no enunciado, que juntavam gosto pelo esporte e gênero masculino. 
Tabela 6: Estatísticas descritivas para as probabilidades estimadas.

\begin{tabular}{c|c|c|c|c|c}
\hline & \multicolumn{5}{|c}{ Estatísticas Descritivas } \\
\hline Item & $\boldsymbol{Q}_{\mathbf{1}}$ & Mediana & Média & $\boldsymbol{Q}_{\mathbf{3}}$ & Desvio Padrão \\
\hline a) P(Masculino e Goste de Esporte) & 0,52 & 0,66 & 0,67 & 0,90 & 0,19 \\
\hline b) P(Masculino ou Goste de Esporte) & 0,50 & 0,60 & 0,61 & 0,80 & 0,21 \\
\hline c) P(Goste de Esporte dado Masc.) & 0,40 & 0,60 & 0,61 & 0,90 & 0,26 \\
\hline
\end{tabular}

Observamos que estas respostas foram dadas sem que a grande maioria dos alunos fizessem qualquer tipo de cálculo, já que estes não souberam ler e utilizar os dados da tabela fornecida, o que mostra o mesmo eu a questão 7 em relação a conceitos não intuitivos. Neste caso o conceito de condicional não se apresentou como intuitivo.

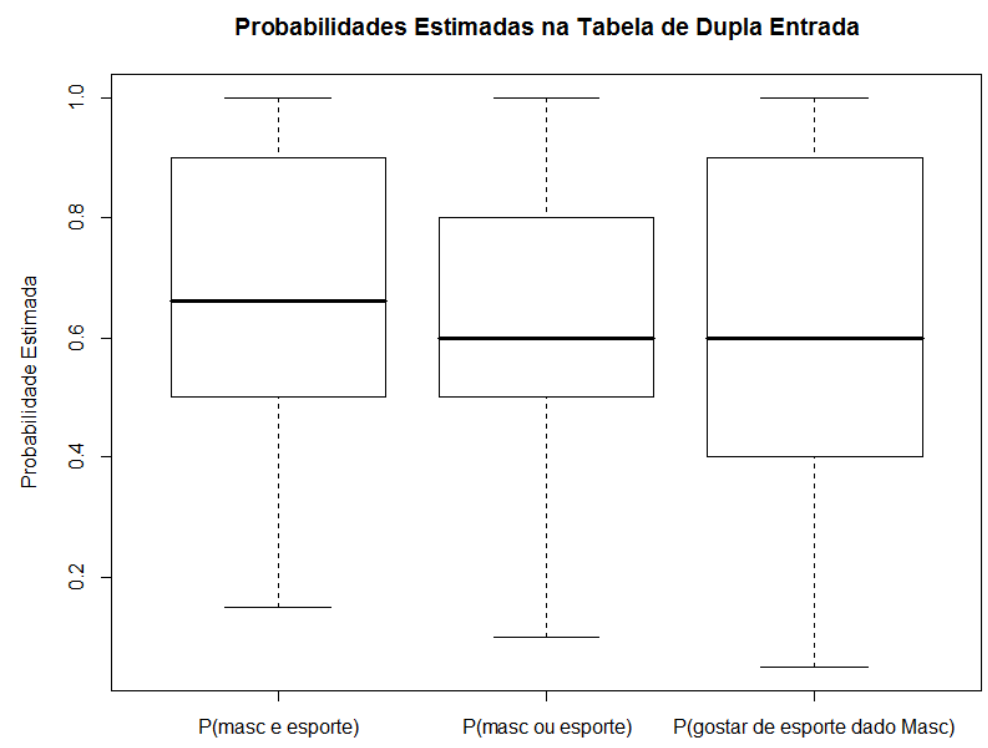

Figura 10: Resultados para as probabilidades estimadas do item a, b, e c $(n=88)$.

A Figura 11, que trata das $50 \%$ respostas centrais (intervalo interquartil), apresenta apenas o item (a) dada a similaridade para os demais itens. Verificamos uma porcentagem inferior a $50 \%$ de justificativas. 


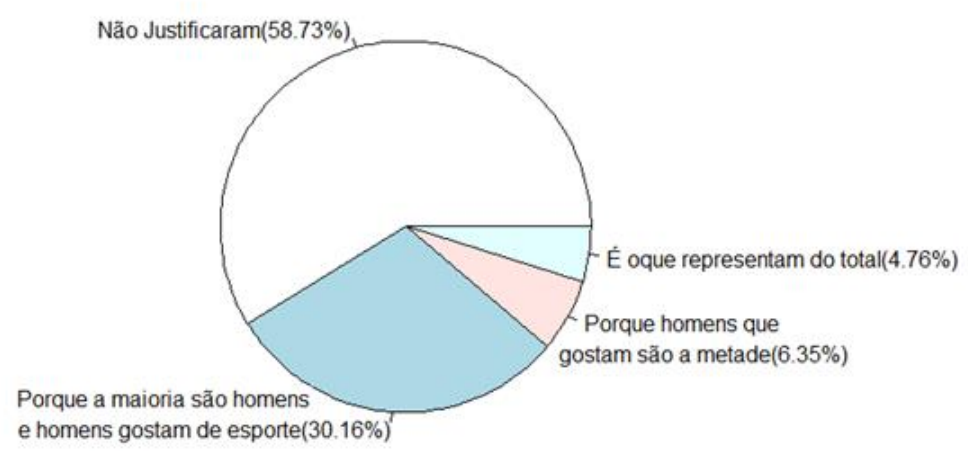

Figura 11: Justificativas para a probabilidade de gostar de esporte e ser do gênero masculino (n=88).

Os alunos que estimaram valores acima do terceiro quartil forneceram as mesmas justificativas, não apresentando mudanças significativas que indicassem qualquer comportamento que destoasse das estimativas anteriores.

Em resumo, observamos que apesar de menos da metade ter justificado, uma tendência em afirmar de acordo com as características e estereótipos do enunciado que o motivo seria "pelo fato da maioria (dos estudantes dos dados da tabela) serem do gênero masculino e estes gostarem de esporte". Portanto, estamos diante do viés de representatividade novamente, em que foram guiados pelo estereótipo do gênero masculino ter predileção por esportes comparados ao feminino, ignorando totalmente os dados da tabela, salvo exatos 5 alunos que observaram para o item (a) serem os homens metade, ou seja, 50 dos 100, justificando sua estimativa baseada no cálculo corretamente.

\subsection{4 - Comentários dos resultados}

Nossa análise acerca dos resultados é a de que as heurísticas e vieses foram observados em todas as questões, bem como os erros de raciocínio estatístico.

A questão 1 acerca das profissões, mostrou fortemente o viés de representatividade, e o fato da confiança nesta heurística de julgamento, utilizando de fato apenas fragmentos de informação, revela que o ensino de probabilidade deve ser focado em uma abordagem que faça com que os alunos não negligenciem as taxas-base, já que em problemas simples isto 
pode até ser evitado, mas em problemas mais intrincados e menos transparentes pode acarretar em erros sistemáticos. As atividades propostas no pós-teste, descritas no próximo capítulo, foram uma tentativa de corrigir este fenômeno, ou ao menos diminuí-lo.

Para a questão 2 e a 3 das sequências de resultados no lançamento de moedas, os vieses foram fortemente encontrados, e o objetivo das atividades é uma abordagem diferente em sala de aula, devendo levar em conta, principalmente, que a fé exagerada em pequenas amostras deve ser eliminada, pois a visão dos alunos, tanto para sua possível vida acadêmica e de pesquisador, como na profissional ou como cidadão, tem que ter o princípio de que sua visão pode ser mais simples e mais coerente do que a intuição guiada por dados escassos ou simples evidências. Estes dados não podem ser ignorados e ainda, devem ser lidos e utilizados de forma correta.

As questões 4,5 e 6 (sobre previsões dos resultados de uma loja, da reincidência de exdetentos e da quebra de uma TV após a garantia, respectivamente), mostraram um certo padrão: quando são conjunturais e familiares aos alunos, tivemos um claro exemplo em que o viés de representatividade não afetou o julgamento da maior parte dos alunos, que trouxeram uma resposta mais conservadora ante o risco, isto é, ao estimar com probabilidade de 0,5 reconhece que qualquer resultado poderia ser possível, considerando os diversos fatores que poderiam trazer uma mudança nos resultados da loja no próximo semestre.

Ainda neste grupo de questões mais próximas da realidade dos alunos, a questão da segurança pública no caso dos presos reincidentes, uma questão que os afeta ou mesmo que cause certa apreensão por sua própria segurança, as respostas não foram compatíveis com o viés de Disponibilidade, ou pelo menos não foram tão afetadas simplesmente pela lembrança de exemplos ou evidências, dadas as considerações e conhecimentos da estrutura da sociedade em que vivem. Portanto, os alunos evocaram ideias associativas apesar de um cenário incompleto e de dados escassos, considerando fatores que trouxeram estimativas para resultados aleatórios e não fizeram estimativas intuitivas induzidas automaticamente.

Em suma, o que levou os alunos nestas últimas três questões a não raciocinarem de forma tão maciça pelas heurísticas como no caso das moedas e das profissões e sim, considerarem argumentos implícitos ou mesmo inexistentes na descrição do problema? Estas considerações abrangem uma nova perspectiva no discurso do aluno, nos casos onde o viés de representatividade e mesmo as intuições estatísticas equivocadas não foram sentidas de forma tão expressivas, e reforçam a ideia de uma prática em sala de aula voltada ainda mais para dados reais e situações - problemas que remetem ao seu dia a dia. 
Os resultados destas questões contextuais corroboram a descoberta, citada por Kahneman (Kahneman,2012), de um estudo no início da década de 1990 de um grupo de psicólogos alemães que se revelou um grande avanço sobre a compreensão da heurística da disponibilidade.

Temos pelos resultados da questão 7 - da estimação da média e a utilização da previsão pelo valor esperado -, que é fundamental propor atividades que fujam do caráter matemático e computacional de suas estimativas. Estas atividades devem propor ao aluno formas de previsão destituídas de um simples valor a ser encontrado, capacitando-o a fazer julgamentos e previsões destituído da preocupação de um valor exato.

$\mathrm{Na}$ última questão (8), apesar do forte viés de representatividade e do desprezo pelos dados da tabela, nosso foco será em atividades que facilitem a leitura destas tabelas e o mais importante, que as tornem essenciais na eliminação ou diminuição dos erros e falácias.

A seguir, colocamos em um quadro resumo as heurísticas detectadas juntamente com as informações da mediana, por representar não só a tendência das estimativas, mas por separar os alunos em dois conjuntos de mesmo tamanho, quanto ao julgamento.

\begin{tabular}{|c|c|}
\hline Enunciado das questões & Respostas e Heurísticas Detectadas \\
\hline $\begin{array}{l}\text { 1. Estimar a chance de Carlos exercer cada } \\
\text { profissão (vendedor, fazendeiro, etc), dados os } \\
\text { estereótipos. }\end{array}$ & $\begin{array}{l}\text { - } \quad \text { Mediana para físico 0,60 e 0,25 para vendedor; } \\
\text { - Tendência a julgar como mais provável Físico: viés de } \\
\text { representatividade pelo estereótipo de Carlos. }\end{array}$ \\
\hline $\begin{array}{l}2 \text { e 3. Fornecer uma estimativa de probabilidade } \\
\text { da moeda ser honesta em cada caso de sequências } \\
\text { de resultados }[(C, K, C, K, K, C),(C, C, C, K, K, K) \text { e } \\
(C, C, C, C, K, C)] \text {. E qual a face mais provável a } \\
\text { sair no próximo lançamento? }\end{array}$ & $\begin{array}{l}\text { - Mediana 0,30 para CCCCKC e 0,50 para CCCKKK e } \\
\text { CKCKKC; } \\
\text { - Tendência a julgar como mais honesta a sequência } \\
\text { CKCKKC e a próxima face de acordo com o formato } \\
\text { da sequência - forte viés de representatividade, com } \\
\text { a fé exagerada em pequenas amostras - a Lei dos } \\
\text { Pequenos Números. }\end{array}$ \\
\hline
\end{tabular}




\begin{tabular}{|c|c|c|c|c|}
\hline \multicolumn{4}{|c|}{$\begin{array}{l}\text { 4, } 5 \text { e 6: Estimar as probabilidades de que uma } \\
\text { loja tenha o mesmo resultado no segundo } \\
\text { semestre, de um ex detento ser reincidente e de } \\
\text { uma TV quebrar após o término da garantia } \\
\text { respectivamente. }\end{array}$} & $\begin{array}{l}\text { - Mediana } 0,50 \text { para a loja voltar ter resultado ruim e } \\
\text { para a quebra de uma TV, e } 0,74 \text { pela reincidência de } \\
\text { presos; } \\
\text { Tendência a respostas conservadoras - viés de } \\
\text { Disponibilidade não detectado no geral, sendo que } \\
\text { apenas um percentual dos alunos (cerca de } 10 \% \text { em } \\
\text { média por questão) optou por respostas mais radicais } \\
\text { levados pelo viés de disponibilidade, citando exemplos } \\
\text { de eventos vividos por pessoas conhecidas ou } \\
\text { enxergando determinados perfis diante do cenário } \\
\text { incompleto. }\end{array}$ \\
\hline \multicolumn{4}{|c|}{$\begin{array}{l}\text { 7. Estimar a nota para um quinto estudante } \\
\text { sorteado, dado que a média do colégio é } \\
\text { conhecida, bem como as quatro notas anteriores. }\end{array}$} & $\begin{array}{l}\text { - } \text { Mediana 4,0. } \\
\text { Tendência a ignorar a média conhecida - caráter } \\
\text { computacional induziu à busca de uma medida via } \\
\text { cálculo. Mesmo para alunos que utilizaram a média } \\
\text { amostral (n=4), de acordo com a mediana das } \\
\text { estimativas, estes arredondaram para o valor } 4,0 \text { com a } \\
\text { preocupação em "acertar" o valor da média. }\end{array}$ \\
\hline \multicolumn{4}{|c|}{ 8. Dada a distribuição dos alunos: } & - Mediana 0,66 para a probabilidade de ser masculino e \\
\hline \multirow{2}{*}{ Gênero } & \multicolumn{2}{|c|}{ Gosta de Esporte } & \multirow{2}{*}{ Total } & gostar de esporte, e 0,60 para os dois outros itens. \\
\hline & Sim & Não & & - Respostas negligenciaram os dados - forte viés de \\
\hline M & 50 & 10 & 60 & $\begin{array}{l}\text { Representatividade pelo estereótipo do gênero } \mathrm{M} \text {, ou } \\
\text { seja, os julgamentos basearam-se em uma imagem }\end{array}$ \\
\hline $\mathrm{F}$ & 30 & 10 & 40 & \\
\hline Total & 80 & 20 & 100 & que o gênero masculino gosta mais de esporte. \\
\hline \multicolumn{4}{|c|}{$\begin{array}{l}\text { Fornecer a } \mathrm{P} \text { (gênero } \mathrm{M} \text { e goste de esporte), a } \\
\mathrm{P} \text { (gênero } \mathrm{M} \text { ou goste de esporte) e } \mathrm{P} \text { (goste de } \\
\text { esporte, sabendo que é do gênero masculino). }\end{array}$} & \\
\hline
\end{tabular}

Quadro 3: Resumo das heurísticas e vieses detectados

\section{2 - Ações didáticas e a experiência em sala de aula}

A abordagem e as atividades para o ensino de probabilidade e estatística a seguir foram pensadas de acordo com os resultados do levantamento do pré-teste, bem como pelas pesquisas que o referencial descrito no capítulo 1 apontou. 
Entre os fatores do referencial que motivaram as ações para sala de aula, que devem ser levadas em conta ao se ensinar probabilidade e estatística, estão os citados no artigo de Batanero et al. (2011), cuja abordagem e formas de raciocínio devem ser considerados para evitar o raciocínio determinístico matemático.

Além disso, de acordo com os resultados do pré-teste e reforçando as ideias principais de Batanero et al.(1994), procuramos pensar nos hábitos mentais que professores e estudantes têm que adquirir para os conceitos fundamentais, tais como usar dados reais e simulações, investigações de associações e explorar representações alternativas.

Estes fatores motivaram as ações para sala de aula, que compõem esta parte do trabalho, em uma tentativa de eliminar ou ao menos diminuir o efeito das heurísticas e vieses, ou seja, de obter um ganho significativo na aprendizagem dos conceitos de probabilidade e estatística de um modo geral.

Todas essas ações contêm um ponto fundamental que se traduz em uma abordagem contextualizada onde se ensina utilizando dados reais, que permitam experiências em sala de aula e que aumentem e ampliem a visão da teoria. Acreditamos que esta abordagem possa ampliar o espectro de raciocínio do aluno para que se sinta mais preparado ao fazer estimativas/previsões em diferentes contextos.

Vamos então elencar uma série de ações que foram tomadas a partir da análise dos resultados do pré-teste e que embasaram todas as atividades realizadas em sala de aula. Seria como uma declaração dos princípios didáticos que nortearam todas as aulas descritas na seção 2.4.2, ministradas nas semanas de 2 a 6 , que podem auxiliar na montagem de sequências didáticas de diferentes naturezas. Após todas as ações serem descritas, será apresentado um quadro (Quadro 4) com as manifestações encontradas em sala de aula.

\section{Ações}

1 - Aproveitar o próprio momento de expor a teoria para coletar os dados, entrevistar os alunos verbalmente e incluir os dados de cada um, para que cada aluno enxergue sua informação individual como um dado real, vivo e atuante no problema.

Olhar os dados desta forma significa observar que os dados não são, ou não seguem um modelo fixo e determinado como estava até então sendo tratado em sala de aula em matemática, conforme discutido na seção anterior sobre o artigo de Batanero et al.(2011). De 
um modo geral, observar que os dados não seguem um modelo fixo é considerar a variação, um dos pilares da estatística em que se considera a incerteza e o erro nos dados contextuais.

A consideração de um fator de erro nos dados em um modelo matemático ou nas medidas que fazemos de ângulos, por exemplo, teria que ser tratada, ainda que de forma gradativa, desde o ensino fundamental, com pequenas questões discursivas, ou abertas, para que se desse aos alunos a oportunidade de pensarem neste aspecto, ou forma de raciocínio.

O aluno visualizar o espaço amostral olhando para o próprio valor que ele ali representa lhe fornece uma visão mais concreta do problema que possui em mãos, e isto pode fazer com que estes dados não sejam negligenciados em seus julgamentos, e assim, uma possível forma de diminuir o viés de representatividade.

2 - Diminuir o formalismo na exposição da teoria de probabilidade significa no nosso caso utilizar pouco, ou talvez suprimir, a linguagem dos conjuntos.

Uma forma que pode ser mais simples de tratar a disciplina é utilizar as tabelas de dupla entrada para os dados, já que a visualização realça o conjunto dos dados de forma resumida, e ainda, o aluno pode ter uma informação que lhe pode ser mais tratável, na forma da linguagem de frequências ou proporções.

Esta é a ideia de Gigerenzer(1994), para quem mudar o formato das questões de probabilidade para freqüências reduz drasticamente os efeitos dos erros de julgamento, alegando a importância do aspecto psicológico na resolução de um problema, isto é, probabilidade parece ser, ao aluno, um ente abstrato, enquanto que freqüência parece ser um ente natural, embora ambas possam ser consideradas matematicamente equivalentes.

Assim, fortalecer estes pontos e formas de raciocínio em probabilidade, pode auxiliar a evitar erros como os cometidos nas questões do levantamento inicial de nosso trabalho, como as profissões, do resultado ruim da loja e da reincidência de presos. Voltaremos a comentar este tópico.

3 - Elaborar questões discursivas, onde se questione o aluno quanto à sua decisão tomada, ou ainda, que ao justificar sua decisão, ele a enxergue como uma forma de aplicar o seu conhecimento dentro de um contexto bem particular, e que assim saiba utilizá-lo dentro de um contexto mais geral. 
Estas abordagens facilitariam, por exemplo, no aprendizado da questão 8, em que foi dada uma tabela e proposta a questão de probabilidade da conjunção, união e probabilidade condicional. Notamos que os alunos encontraram muita dificuldade em notar diferenças nos enunciados e consideraram os dados sem se ater às evidências relacionadas às características do problema, como o gênero.

Mas sem dúvida, o ponto principal desta abordagem é trazer o aluno à reflexão para que não incorra no erro de julgamento como na heurística das concepções errôneas de possibilidade, sobre a fé exagerada em pequenas amostras. Neste caso, o aluno terá que refletir que os valores que possui não fazem com que aconteçam, e que ele não pode ter certeza a priori sobre uma extração ou sorteio.

Mais do que diminuir ou extinguir uma heurística e viés, é entender, de fato, a teoria das probabilidades.

4 - A probabilidade encarada com menos formalismo, tem que adquirir o caráter experimental da busca de um modelo. Dentro da crítica ao formalismo que Batanero et al.(2011) observaram, o fator de se ensinar através de experiências fenomenológicas como a simulação, vai de encontro à forma como se ensina matemática, em que frequentemente se subestima a conjectura estatística da incerteza.

Uma atividade muito citada em livros didáticos, recentemente tem sido até incorporada a livros do ensino fundamental, é a do lançamento de moedas ou dados pelos alunos em sala de aula.

A simulação em sala de aula para o ensino de probabilidade, no entanto, requer a observação de dois pontos fundamentais: a suposição teórica tem que ser explicitada no início da atividade, pois é ela que será testada, ou averiguada; o outro cuidado é a discussão que tem que acompanhar a atividade, uma questão discursiva que indague ou solicite uma decisão diante do resultado da experiência, fundamental para que o aluno integre e conecte o conhecimento da teoria das probabilidades e seu sentido.

Uma proposta de atividade de probabilidade está descrita em Cordani (2012), em que os alunos executam uma quantidade de lançamentos de moedas, enquanto calculam a frequência acumulada de caras até aquele momento, usando um gráfico de linhas para descrever o comportamento da freqüência de caras, para verificar assim a suposição teórica de 
probabilidade 0,50 para o resultado cara (podendo esta atividade ser proposta também sem nenhuma suposição inicial).

A experiência além de ser enriquecedora forma de ampliar a visão fenomenológica como no artigo de Batanero et al.(2011), é uma tentativa de diminuição do viés da Concepção errônea das chances, já que, conforme Tversky e Kahneman(1974) atestaram, as pessoas esperam que a probabilidade teórica de sair cara em um lançamento de 0,50, que é um fenômeno global, esteja representada localmente a cada lançamento.

Os alunos assim terão uma oportunidade de verificar, a cada lançamento, que é possível uma sequência de coroas, ou de caras, mas que o que importa é o resultado de toda a sequência de lançamentos, o que poderão verificar no próprio gráfico da frequência acumulada, por eles construída.

Importante salientar a discussão ao final da atividade, para uma reflexão sobre a teoria, onde se busca destacar os principais pontos que o aluno considerou para julgar como honesta a moeda, como a primeira questão a seguir:

\footnotetext{
"De acordo com a experiência, pode-se dizer que sua moeda é honesta? Justifique."
}

A outra questão busca testar justamente a diminuição do viés da concepção errônea das chances, que está dentro do fenômeno da representatividade; bem como o que representa realmente saber sobre a probabilidade de 0,5 de sair qualquer face da moeda, isto é, um valor teórico que fornece na verdade este grau de certeza sobre a previsão do resultado:

Se sua moeda é honesta, poderia acontecer que em 5 lançamentos só saísse 1 cara? Justifique.

Esse questionamento vai direto ao encontro do viés de representatividade, de se fiar em sequências curtas de um processo aleatório, e ainda, verifica se o aluno entendeu o efeito que a convergência mostra e significa, para a teoria de probabilidade.

Por fim, a decisão em probabilidade deve definitivamente se desvincular da forma como é feita em matemática, conforme discutido em Batanero et al.(2011), onde se conclui de forma dedutiva a partir de definições. 
5 - Contribuir com atividades em sala para que o aluno desenvolva um raciocínio de forma diferenciada ante a incerteza é fundamental para compreender a teoria das probabilidades.

Ao se corrigir a experiência anterior e fazer a devolutiva com os comentários pertinentes às justificativas propostas aos alunos, é interessante trazer uma discussão que os envolva ainda mais com a teoria, através da prática. Após ouvir os comentários dos alunos sobre a correção, dirigir-se à classe propondo uma atividade, que retiramos de um artigo de Gelman e Glickman (2000), contendo atividades cuja ênfase foi a participação efetiva dos alunos no nível de introdução à probabilidade e estatística.

A ideia demonstrada pelos autores é envolver os alunos em uma aprendizagem mais relevante, diante dos dados, principalmente quando os resultados contra-intuitivos aparecem (citam inclusive o trabalho de Tversky e Kaheman para o caso específico desta atividade, o fenômeno da Lei dos Pequenos Números dentro do viés de Representatividade), motivando-os a aprender como os métodos em probabilidade e estatística podem ser usados para explicar a variação no mundo real.

A atividade, que na verdade é um desafio, é chamada pelos autores de "Lançamento de moedas: real x falso" (Gelman e Glickman,2000), que descrevemos a seguir:

\footnotetext{
"Vou propor um desafio à sala: vou me ausentar por uns minutos da sala, e enquanto isso vocês se dividam em dois grupos. O representante de um dos grupos irá até a lousa escrever uma sequência de 6 lançamentos de uma moeda, totalmente inventada pelo grupo. O representante do outro grupo irá até a lousa escrever uma sequência de 6 lançamentos resultantes de jogar de fato uma moeda também 6 vezes. Após terminarem, um aluno irá até o corredor me chamar, e eu, ao adentrar a sala, vou tentar adivinhar qual sequencia foi inventada, e qual foi resultado de jogadas."
}

Este desafio procura reforçar a ideia de um processo aleatório onde, em uma sequência de lançamentos, é claramente plausível saírem cinco caras e apenas uma coroa, algo que os desafia novamente, mas agora no sentido de reforçar o que foi visto na experiência, e nova oportunidade para verificar a possível diminuição ou eliminação do viés de representatividade.

O mais importante no desafio, é que os alunos notem que sequências de resultados repetidos é muito mais comum de acontecer do que uma série alternada, até porque uma série alternada de modo sistemático é uma sequência provavelmente não aleatória. 
6 - Outra forma de discussão associada a este tópico poderia começar com a questão:

"Qual a probabilidade de germinação de uma semente?"

Nesta questão, característica de uma situação de resultado dicotômico (germinar ou não germinar), estamos buscando um sentido para um valor de probabilidade, que não pode e nem deve simplesmente ser padronizada como sendo $50 \%$ de chance diante da incerteza. Neste caso a discussão seria encaminhada para a realização de experimentos para se estimar esta probabilidade, da mesma forma que o experimento aleatório do lançamento de moedas.

Ao formular esta questão ao grupo, caso sejam dadas respostas de $50 \%$, podemos então perguntar se uma semente deste tipo poderia ser comprada por um produtor, sabendo que só teria esta chance de germiná-la. Outras respostas a princípio podem surgir, como as que se aproximem de valores plausíveis para um produto comercializável, algo em torno de 90\%. A dúvida irá se instalar e o professor terá um campo fértil de discussão.

Uma ideia seria propor uma visita a uma loja de produtos agrícolas, ou até mesmo a supermercados, nos quais é possível encontrar envelopes com sementes de verduras e legumes. O aluno será orientado a verificar no verso a informação que contém a probabilidade daquela semente germinar, e em seguida, anotar as informações essenciais que corroboram a teoria, como: a probabilidade de germinação, espécie de semente e principalmente, as condições do plantio, que são as condições nas quais o produto foi testado em uma experimentação agrícola. Será interessante a discussão dos experimentos aleatórios realizados em agricultura para produzir os valores de probabilidade de germinação.

Os alunos devem aprender a considerar fatores como a medida e seus atributos e imprecisões para os dados, para que desenvolvam as noções de incerteza e variabilidade no desenvolvimento inicial de estatística e de probabilidade.

7 - Outra ação propõe que os alunos pensem no desenvolvimento de procedimentos estatísticos hipotéticos para a estimação de probabilidade, ressaltando a importância das condições necessárias para que sejam procedimentos aleatórios, repetidos sob as mesmas condições.

Esta reflexão feita pelo aluno pode ajudar também a elucidar e talvez sanar os problemas das heurísticas de representatividade e disponibilidade que levam a erros sistemáticos, já que, ao "criar” uma situação ou procedimento aleatório, o aluno observará que 
a probabilidade é uma medida de incerteza em que não se pode negligenciar os diversos fatores que a afetam, e a intenção desta atividade é a de que o aluno identifique o espaço amostral, tão importante para a estimação.

Quando o aluno enxerga a probabilidade como medida de incerteza, atesta a importância do "olhar os dados", o que foi discutido na seção anterior acerca das diferenças essenciais entre o pensamento matemático e estatístico, do artigo de Batanero et al.(2011), onde os dados são contextuais, valores possíveis para um determinado evento, o que foi visto na experiência em sala de aula.

A atividade deve ser aplicada após uma aula preliminar, contendo dois exemplos em sala, para serem resolvidos juntamente com os alunos, para em seguida, após discussões que as tornem ainda mais desafiadoras, propor a atividade individualmente, contendo quatro ou cinco questões que solicitem apenas procedimentos, ou experimentos para a estimação da probabilidade do evento proposto.

O questionário pode conter questões como as seguintes que, neste caso, já foram utilizadas no pré-teste realizado neste trabalho:

\footnotetext{
Para os casos abaixo, descreva um procedimento estatístico para se estimar as probabilidades nos casos.

Q1. Probabilidade de um detento que cumpriu pena no Brasil ser reincidente.

Q2. Probabilidade de uma TV quebrar um mês após o término da garantia de um ano.

Q3. Probabilidade da previsão do tempo errar a previsão do dia seguinte?
}

O questionário solicita procedimentos que requerem uma abordagem frequentista da probabilidade, que se observe a importância dos dados, do sorteio de uma amostra de uma população.

Esta atividade pode ser aplicada após uma série de exercícios de probabilidade com ênfase na abordagem frequentista, sendo importante que se observe na resolução dos exemplos, fazendo com que observem o espaço amostral, como é a sua estrutura, como são consideradas as possibilidades para o cálculo da probabilidade do evento em questão.

Reiteramos por fim a importância da presença da interação entre estatística e a probabilidade, conforme citado anteriormente, em que a probabilidade é considerada não como um conjunto de dados livres, mas como um modelo gerado por um processo aleatório, com uma visão estatística, como sugerido por Franklin,C.(2012): 
"A probabilidade deve ter ênfase apenas na maneira como é utilizada no pensamento estatístico."

Assim, nas semanas de 2 a 6, como já comentado, foram desenvolvidas as ações propostas e os alunos se envolveram com a discussão de vários pontos colocados pelo professor. O Quadro 4 apresenta algumas das experiências realizadas em sala de aula, baseadas nestas ações, com relatos de algumas intervenções dos alunos.

\begin{tabular}{|c|c|}
\hline Ações & Experiência e Heurísticas \\
\hline $\begin{array}{l}\text { 1. Coleta de dados durante a } \\
\text { aula }\end{array}$ & $\begin{array}{l}\text { - Construção de uma tabela de dupla entrada: "Preferência musical” por } \\
\text { "Gêneros" para estimar probabilidades. Participação efetiva dos alunos; } \\
\text { - Com a pergunta posta: "Qual a probabilidade de um aluno sorteado ao } \\
\text { acaso seja homem ou goste de Rock?” bem como outras utilizando a } \\
\text { probabilidade da União e Intersecção, a informação por frequência deu } \\
\text { maior fluidez à aula; }\end{array}$ \\
\hline $\begin{array}{l}\text { 2. Abordagem com exemplos } \\
\text { contextualizados, mudança no } \\
\text { formato da informação com } \\
\text { preferência para frequências e } \\
\text { uso de tabelas a formalismos. }\end{array}$ & $\begin{array}{l}\text { - Outra questão proposta "Qual a probabilidade desta aluna que está } \\
\text { entrando nesta sala agora goste de Rock?" Os alunos, ao notarem a aluna } \\
\text { toda vestida de preto, respondem que "dada sua roupa, esta probabilidade é } \\
\text { alta". Seu traje tinha o estereótipo do tipo musical: o que mostra a } \\
\text { permanência do viés de representatividade. } \\
\text { - Discussão do erro pelo estereótipo. }\end{array}$ \\
\hline 3. Questões discurs & - $\quad$ Experiência de simulação com moedas em duas aulas seguidas; \\
\hline 4. $\mathrm{Sin}$ & $\begin{array}{l}\text { - Incômodo dos alunos com sequências de resultados iguais, viés da Lei dos } \\
\text { Pequenos Números detectado: orientação para que seguissem com a } \\
\text { experiência dando ênfase ao resultado global, já que em uma moeda } \\
\text { honesta, qualquer sequência sistematicamente balanceada tem baixa } \\
\text { probabilidade de ocorrer em um processo gerador aleatório; } \\
\text { - Finalização com o gráfico da frequência acumulada sem grandes dúvidas; } \\
\text { - Questões discursivas: levantamento mostrou grande maioria apontando } \\
\text { corretamente na primeira questão de acordo com a convergência do gráfico } \\
\text { (considerado intervalo de aceitação de } 0,40 \text { e } 0,60 \text { ); } \\
\text { Segunda questão discursiva: } 40 \% \text { dos alunos (quase metade) responderam } \\
\text { incorretamente quanto à sequência de resultados repetidos: novamente } \\
\text { permanência do viés de representatividade. }\end{array}$ \\
\hline
\end{tabular}




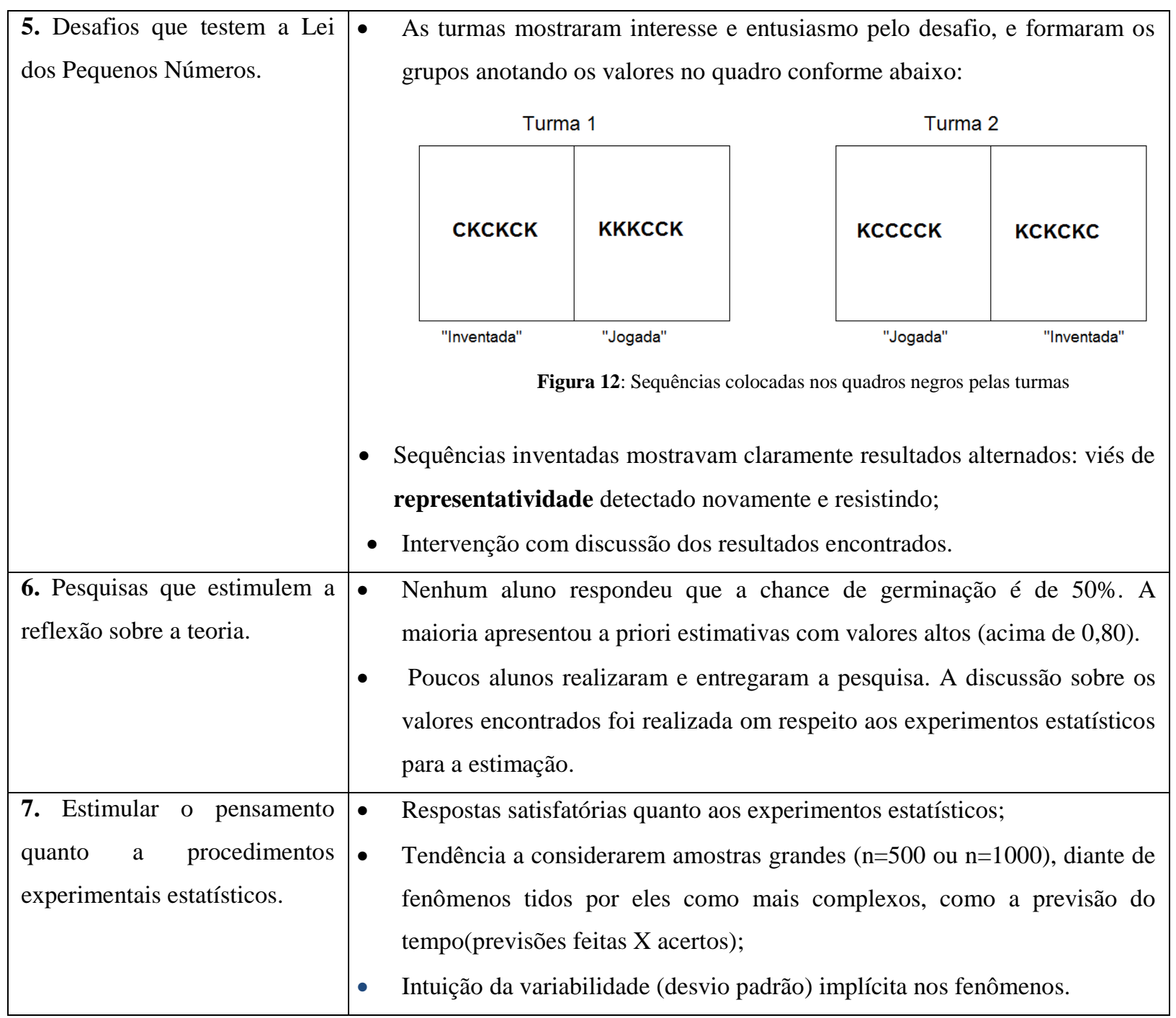

Quadro 4: Resumo das propostas e a experiência em sala de aula

\section{3 - Análise após as atividades}

Após o término do bimestre e da aplicação das atividades propostas para a sala de aula, foi aplicado um teste com as questões apontadas para o mapeamento das heurísticas de representatividade e disponibilidade no início da pesquisa, ou seja, antes dos alunos terem qualquer tipo de treinamento em probabilidade e/ou estatística.

O tempo das aulas e atividades ficou entre o início da segunda semana e o final da sexta conforme o cronograma inicial, logo, contamos efetivamente com 5 semanas entre o pré-teste (sondagem) e o pós-teste (retenção). Neste ínterim foram aplicadas 4 atividades de 
avaliação contendo em média 5 questões cada uma. Todas as atividades foram feitas em duplas, com a possibilidade dos alunos realizarem-nas com consulta ao material. Estas atividades também nos serviram de base para algumas observações, que faremos na análise dos resultados.

Para medir a eficácia das ações em sala de aula, selecionamos três questões para mapear as heurísticas, colocadas de acordo com a numeração do questionário de sondagem do primeiro momento de pesquisa. Além disso, incluímos uma quarta questão similar à questão 3 mas com enunciado relacionando probabilidades ao invés de tabela de freqüências. Os resultados estão descritos a seguir.

\subsubsection{Aplicação dos Testes (Testes de Retenção) e a análise dos resultados}

Primeira Questão: A primeira questão investigou a eficácia das atividades quanto à diminuição ou eliminação da heurística de representatividade:

Carlos é muito tímido e retraído, mas sempre prestativo e atencioso com as pessoas, necessita de organização e ordem pois é muito detalhista. Para cada profissão abaixo dê a chance de $0 \%$ a 100\% (probabilidade) que, em sua opinião Carlos poderia ter e, em seguida, justifique o valor dado:
a) Vendedor;
b) Fazendeiro ou agricultor; c) Físico;
d) Advogado; e) Engenheiro

Esta questão foi aplicada uma aula antes da prova bimestral, exatas cinco semanas após sua primeira aplicação, em que foi distribuída a questão em uma tira de papel, orientando que não era necessária a identificação. Diante das mesmas dúvidas apresentadas anteriormente foi explicitada a forma de como responder à questão, apresentando uma estimativa para cada profissão seguida de suas justificativas. O número total de alunos presentes que entregaram a questão foi 74 .

Grande parte das turmas não se recordava da questão e de suas características, enquanto que os que a reconheceram questionaram o sentido da sua aplicação desta questão, sendo informado a eles que se tratava de verificar a atuação em resposta às aulas. 
A partir da Figura 13 verificamos as diferenças mais sensíveis entre os dois momentos de aplicação nas profissões de vendedor e físico, com a inversão das estimativas de probabilidades.

Para analisar mais detalhadamente estas novas respostas, vamos seguir a estrutura da análise feita na seção 3.1.3., ressaltando os principais pontos do pós-teste.

Todos os 74 alunos responderam à questão, e o percentual de respostas sem justificativas se manteve no patamar de $10 \%$ a $25 \%$.

A profissão que teve mudança mais sensível foi a de vendedor, na qual a mediana passou de 0,25 para 0,50, deixando de concentrar $75 \%$ dos alunos abaixo de 0,40 para uma distribuição praticamente uniforme entre 0 e 1 . A outra profissão foi a de físico com a mediana que antes estava em 0,60 caindo consideravelmente para 0,30, diminuindo sensivelmente a opção pela profissão, deixando de lado o estereótipo do perfil descrito para Carlos (viés de representatividade), levando em consideração a taxa base de vendedor na população.

Nas demais profissões, apesar de leve queda na mediana (cerca de 0,10) nos três casos, as distribuições apresentaram distribuições com tendências similares, com alterações na variabilidade também pouco notáveis (exceção da profissão de advogado que teve escolha diminuída) conforme a Figura13:
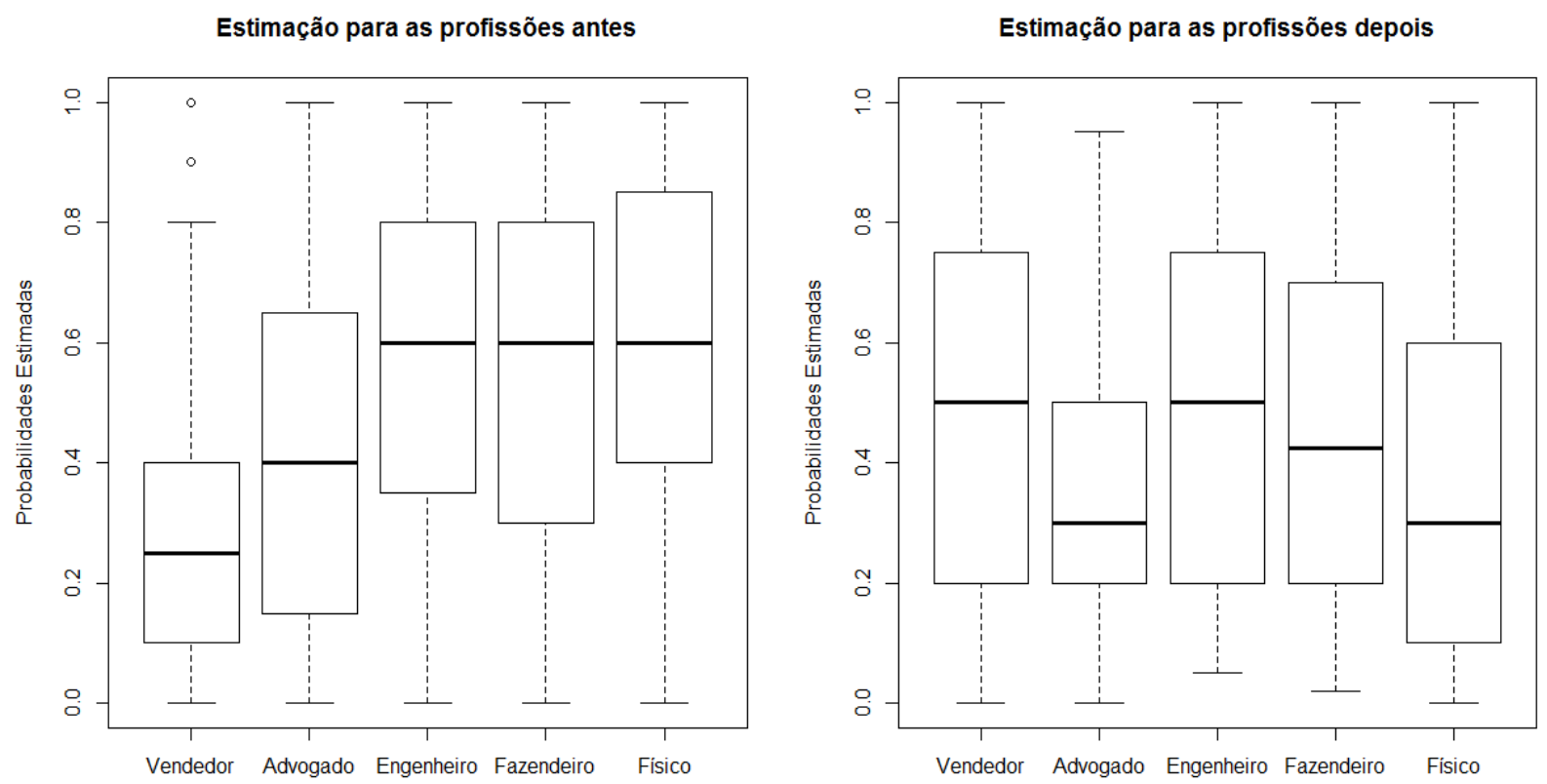

Figura 13: Comparativo geral das profissões, antes e após as atividades. 
O panorama geral do comparativo das medianas indica uma mudança de inclinação pelas profissões, que antes partiam da menos provável como vendedor até a mais provável de físico.

Após o curso, a profissão de vendedor se tornou a mais provável, enquanto que a menos provável ficou a de físico. No entanto, esta mudança não se deu em sua totalidade por considerações das frequências das profissões de acordo com a população considerada pelos alunos. Uma análise das justificativas dos casos mais sensíveis nos deu uma visão mais clara da mudança.

As justificativas da profissão de vendedor, conforme Figura 14, para os alunos que estimaram probabilidades dentro dos $50 \%$ centrais (de 0,20 a 0,75 ), mantiveram-se de acordo com os estereótipos e do viés de representatividade, assim como no pré-teste, apesar de a probabilidade de vendedor ter crescido no pós teste. Somente uma quantidade reduzida (4 alunos), apresentou considerações das frequências das profissões na nossa população em questão nas justificativas: "Há mais cargos de vendedor!", ou "Há mais vendedores no mercado de trabalho!" Ou seja, cresceu a probabilidade de vendedor no pós-teste sem ter sido acompanhada de justificativas adequadas (taxa-base) na mesma proporção.

O efeito das atividades aplicadas durante o bimestre letivo a princípio foi muito reduzido, fazendo com que apenas uma parte muito reduzida dos alunos não negligenciassem as taxas-base para se guiarem pelos estereótipos.

Justificativas dos alunos ( $50 \%$ do total) que atribuíram probabilidades entre 0,20 e 0,75

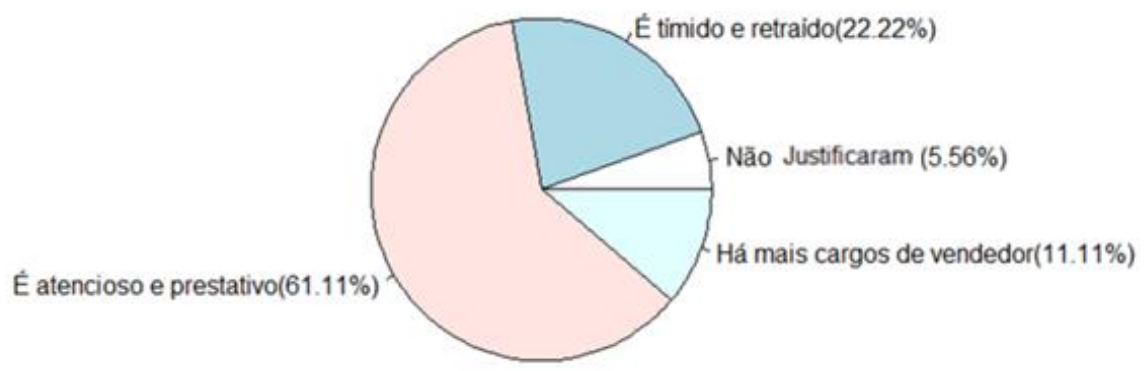

Figura 14: Justificativas das estimativas da profissão de vendedor após as atividades $(\mathrm{n}=37)$. 
Para as profissões de advogado, fazendeiro e engenheiro, as justificativas se mantiveram com foco nas características apresentadas de Carlos.

$\mathrm{Na}$ profissão de físico, que teve a maior mudança dentre todas as profissões, com a mediana caindo de 0,60 para 0,30, tivemos ainda 75\% dos alunos julgando como probabilidade de exercer esta profissão no pós-teste abaixo do valor da mediana no pré-teste.

Nas justificativas para físico, também no grupo dos $50 \%$ centrais, houve uma mudança com relação ao pré-teste, aparecendo uma nova parcela de $23 \%$ justificando o fato de ser "uma pequena parcela da população", conforme Figura 15, o motivo pela probabilidade estimada ser baixa.

Justificativas dos alunos ( $50 \%$ do total) que atribuíram probabilidades entre 0,10 e 0,59

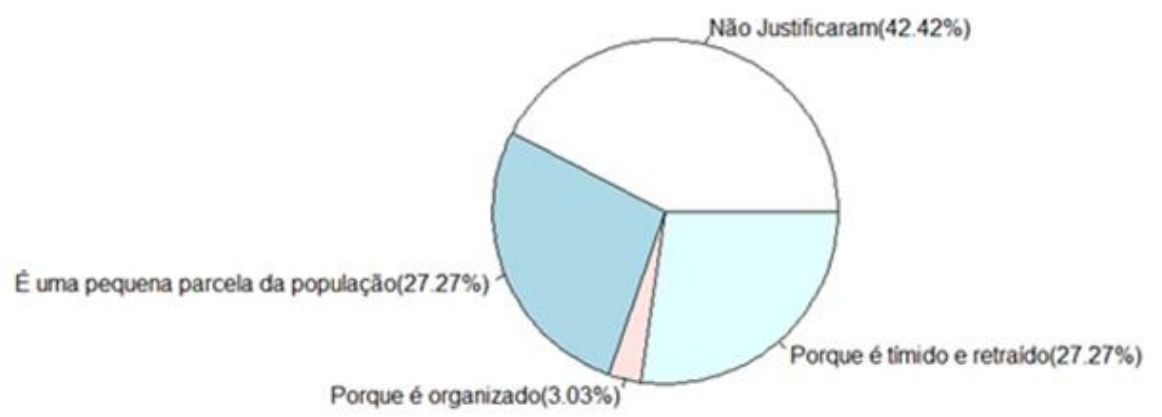

Figura 15: Justificativas das estimativas da profissão de físico após as atividades $(\mathrm{n}=37)$.

Comparando com o panorama geral dos valores até o terceiro quartil, de fato as profissões de vendedor e físico foram as mais sensíveis, e se mostraram também na mudança do terceiro quartil em vendedor, de 0,40 para 0,75 , isto é, $75 \%$ dos alunos passaram a estimar como alta a probabilidade de exercer esta profissão.

Outro fator que chama a atenção é o aumento da variabilidade, visível no intervalo interquartil conforme a Figura 13, cujo tamanho foi aumentado de 0,30 para 0,55, dando mais evidências, além da nova parcela que considerou as taxas base considerando a população, de alguma inclinação para mudanças no julgamento, isto é, levando em conta outros fatores que não o estereótipo apresentado, que fora tão significativo no pré-teste.

Um fato chamou a atenção, que foi a característica "timidez", tendo um impacto muito grande nas decisões, em que não só apareceu em praticamente todas as análises das profissões, em todos os patamares das chances, como apresentou evidência de forte influência 
como fator negativo para os alunos, como sinônimo de falta de capacidade intelectual por eles, e assim, manteve-se como fator decisivo no julgamento das probabilidades, dentro do viés de representatividade.

Por fim, para as estimativas acima do terceiro quartil, e atentos às profissões com mudanças mais significativas, como a de vendedor, observamos que as decisões foram menos afetadas pela representatividade, pois a consideração para o fato de que há mais vendedores na população em questão aumentou de $11 \%$ do grupo central, para $45 \%$ neste grupo, com frases do tipo: "Há mais vendedores no mercado de trabalho".

Em suma, as mudanças no panorama geral das estimativas para as profissões foram significativas, mas não eliminaram completamente o viés de representatividade, mesmo com a preparação anterior - embora tenha, como comentado, diminuído a sua incidência. Os estudos de Tversky e Kahneman(1983) já apontavam para violações resistentes inclusive em profissionais com relevante treinamento em estatística, no estudo de Gigerenzer(1994), não houve eliminação das heurísticas.

Por outro lado, a resistência observada de antemão na aplicação das atividades e no curso das aulas, tem uma consideração importante contida no mesmo artigo de Gigerenzer, sobre o paleontologista Stephen Jay Gould, que escreveu em seu livro Bully for brontosaurus. Further reflections in natural history (Gould,1992), além de vários tópicos em história natural, sobre o uso das estatísticas com observações sobre o programa Heurísticas e Vieses, que apesar de fascinado pelas idéias dos exemplos, sua mente ainda continuava dizendo que a descrição continuava fazendo sentido.

A “descrição continuar a fazer sentido", no caso o estereótipo de Carlos, significa que, mesmo os alunos tendo uma ideia sobre o problema de se negligenciar as taxas-base (no caso há muito mais vendedores na população), as características (tímido, retraído e detalhista) continuariam a fazer sentido para exercer uma profissão como a de físico. Mais à frente faremos uma análise desta controvérsia sobre o programa e suas consequências no nosso estudo.

\section{Segunda Questão:}

A questão continha o mesmo enunciado anterior, sendo solicitadas as justificativas para cada estimativa: 
Considere as sequências abaixo de resultados no lançamento de uma moeda. Em cada caso, forneça a sua estimativa em porcentagem da moeda ser honesta (ou seja, a chance de sair cara $\mathrm{K}$ é igual à de sair coroa $\mathrm{C}$ ), considerando que cara e coroa sejam os únicos casos possíveis. Justifique o valor dado por você.
a) $\mathrm{C}, \mathrm{K}, \mathrm{C}, \mathrm{K}, \mathrm{K}, \mathrm{C}$;
b) $\mathrm{C}, \mathrm{C}, \mathrm{C}, \mathrm{K}, \mathrm{K}, \mathrm{K}$;
c) C,C,C,C,K,C

Um item adicional dentro da mesma questão foi colocado:

“Como você poderia ter mais certeza sobre a honestidade da moeda"?

Esta questão avaliou, dentro da heurística de representatividade, como se comportou o viés das concepções errôneas das chances, tanto para considerações globais do processo aleatório, quanto para o julgamento com respeito ao próximo lançamento.

Esta questão foi aplicada no teste após o curso, de acordo também com o cronograma de 5 semanas de intervalo entre o primeiro e o segundo testes, e foi apresentada como questão da prova bimestral, com a totalidade dos alunos considerados freqüentes na escola, o que correspondia a um total de 97 alunos (os ausentes no dia marcado para a prova, puderam fazêla na aula seguinte). Importante observar que a prova continha 7 questões, com um tempo reservado de duas aulas seguidas para resolução. Lembrando que, apesar de termos quase 10 alunos que não receberam as orientações do pré-teste, estes frequentaram as aulas e participaram das atividades propostas.

Os resultados mostraram que para os três tipos de sequências de lançamentos, não houve mudanças tão sensíveis quanto as observadas na questão anterior das profissões. Novamente seguimos a análise de acordo com a estrutura da análise do pré-teste, comparando os principais itens.

Nesta questão, o percentual de alunos que deixaram em branco (cerca de $12 \%$ já considerando 9 alunos que não fizeram o pré-teste) se manteve próximo ao do apresentado no pré-teste (cerca de 11\%), assim como o alto percentual de estimativas sem justificativas, revelando ainda muitas dúvidas dos alunos com este tipo de questão, a qual verificamos possuir um teor mais abstrato e não contextual, que gerou dificuldades maiores do que as encontradas nas questões contextuais como das profissões, ou do resultado de uma loja, etc. Verificamos em cada caso as alterações, que podem ser visualizadas na Figura 16. 
Na sequência CCCCKC: a mediana não foi alterada, permanecendo em 0,30 como sendo baixa a chance da moeda ser honesta, mas levando a uma maior variabilidade após as atividades, o que significou um pequeno grupo de alunos a mudar suas concepções.

Na sequência CCCKKK: a mediana permaneceu em 0,50. Apesar da distribuição das estimativas ter sofrido alteração nos valores centrais, onde antes a mediana coincidia com o $1^{\circ}$ Quartil passou a coincidir com o $3^{\circ}$ Quartil, em geral as estimativas continuaram relativamente próximas de 0,50 , com variabilidade semelhante.

Na sequência CKCKKC: a mediana passou de 0,50 para 0,60, mantendo a distribuição praticamente inalterada, na variabilidade e nos quartis, e tendo portanto, pouca mudança em consideração à honestidade da moeda nesta sequência.
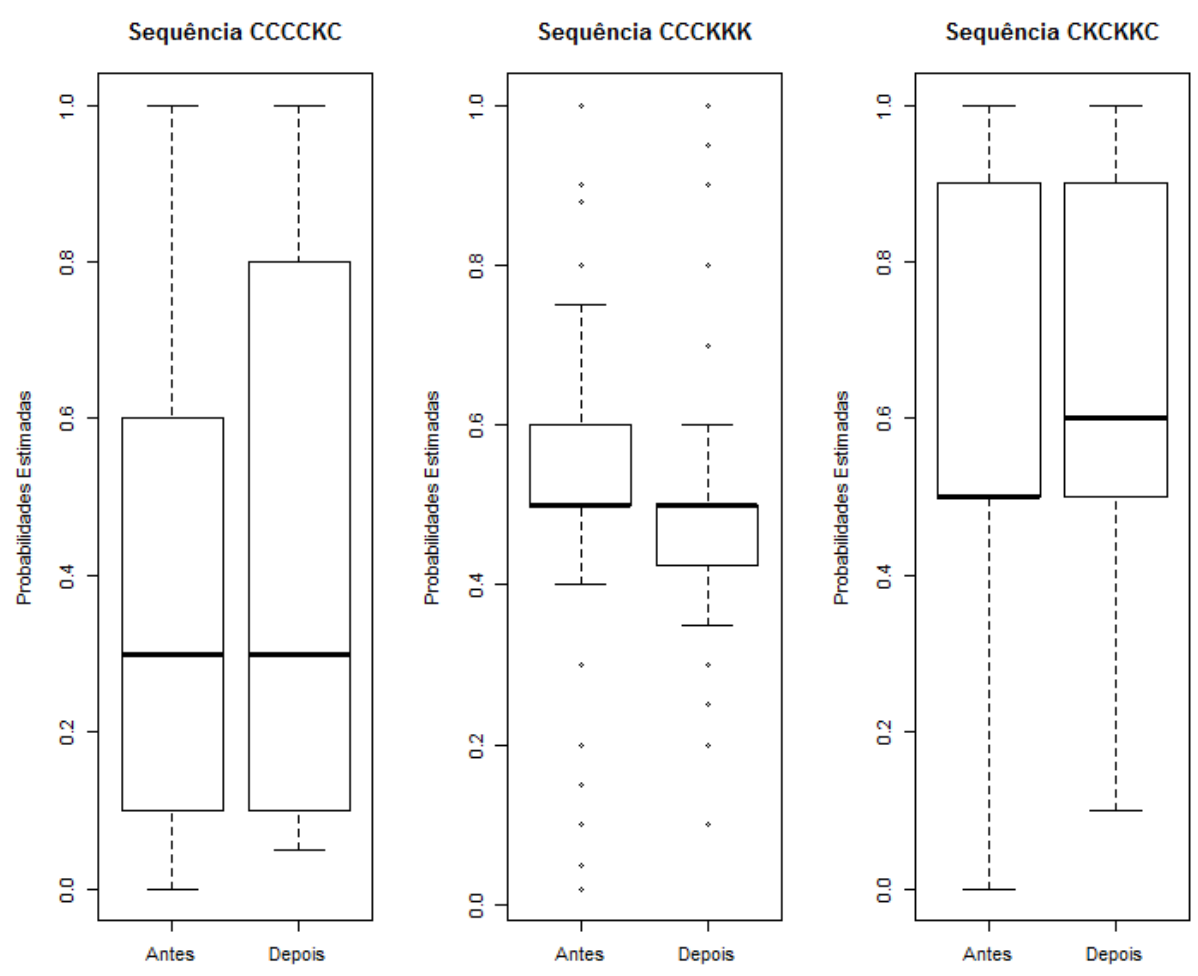

Figura 16: Comparativos das estimativas para as sequências antes e após as atividades.

Os fatores que justificaram estas alterações, ainda que não significativas com relação à questão 1, na preferência dos alunos após o curso, no entanto, permaneceram atrelados à representatividade, e como foram semelhantes para as três sequências, agrupamos todas as respostas em um só gráfico, para um total de 85 alunos respondentes, como segue: 


\section{Justificativas para as sequências}

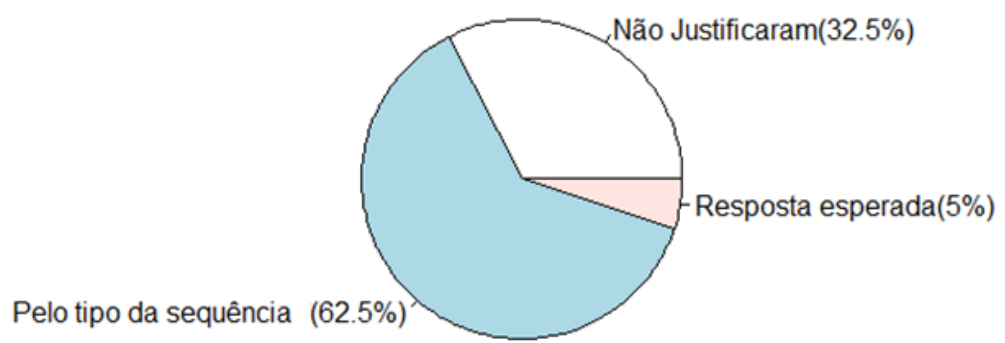

Figura 17: Justificativas globais para as estimativas das sequências após as atividades.

Para a resposta esperada, isto é, que a chance é a mesma para todas as sequências, ou de forma razoável o aluno poderia apresentar certo tipo de contagem para estimar a probabilidade, tivemos apenas $5 \%$ dos alunos. Já os $62,5 \%$ justificaram pelo viés de representatividade, observado nos seus argumentos: -"Porque está equilibrada"; "Pois tem três caras e três coroas"; "Pois está mais balanceada, ou menos balanceada"; "Pois é mais difícil sair cara, ou vice-versa".

As outras análises do terceiro quartil, bem como das justificativas acima deste, não tiveram mudanças significativas.

O novo item ("Como você poderia ter mais certeza sobre a honestidade da moeda"?), apresentou inconsistência nas respostas para grande maioria dos alunos, isto é, respostas que não levaram em consideração o cenário do problema proposto, no sentido das condições apresentadas, mas que também não forneceram a resposta esperada, conforme a Figura 19, 45\% deram respostas do tipo: -"Teria mais certeza se eu jogasse a moeda"; "Faria um cálculo de probabilidade"; "Faria um teste"; "Olharia o gráfico".

A última justificativa revelou o fato dos alunos terem vaga lembrança da atividade do lançamento de moedas, de onde retiraram a ideia de verificar o gráfico que no caso, seria o da convergência na experiência. Isso mostra a importância da reflexão feita logo após a experiência da planilha dos lançamentos das moedas, conforme havíamos apontado como um item importante nas listas de atividades, no quesito de questão discursiva.

Também observamos algumas evidências de reminiscências da atividade anterior na justificativa de exatos 5 alunos, dizendo que "jogariam várias vezes até equilibrar a moeda"; 
ou seja, recordando-se da convergência da frequiência acumulada. Aqui notamos que os alunos não conseguiram aplicar a ideia do fenômeno - a moeda ser honesta não depende de pequenas sequências, e sim, do resultado global após um número considerável de lançamentos - para resolver uma questão onde fora apresentada apenas uma pequena sequência de resultados.

\section{Como poderia ter mais certeza sobre a honestidade?}

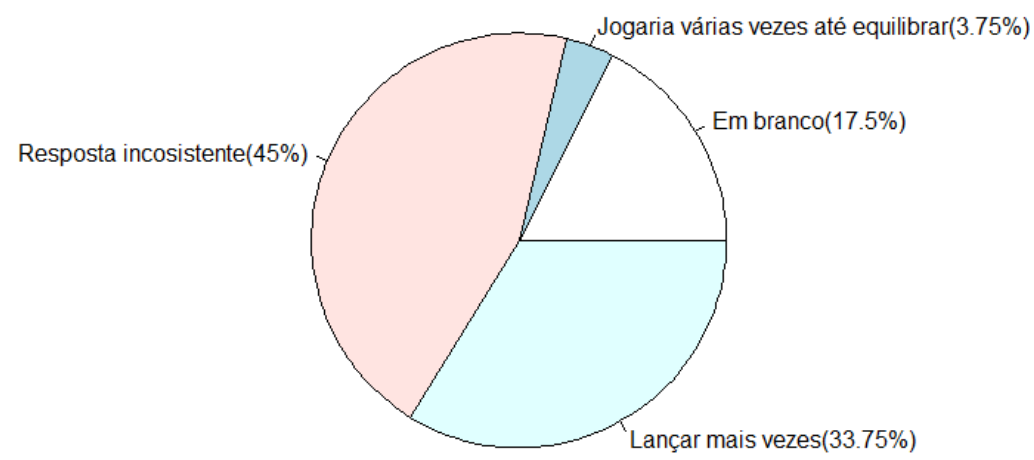

Figura 18: Respostas das sugestões para "a maior certeza da honestidade da moeda"

Novamente foi observada uma resistência no viés de representatividade, mas neste caso a resistência foi maior do que na questão anterior, algo que analisamos e segue ilustrado mais a frente do trabalho em um panorama geral sobre as heurísticas e vieses.

\section{Terceira Questão:}

Consideremos 100 alunos que cursam o ensino médio em um colégio distribuídos conforme a tabela abaixo. O diretor vai sortear um aluno para representar a escola em um evento da cidade:

\begin{tabular}{c|c|c|c}
\hline \multirow{2}{*}{ Gênero } & \multicolumn{2}{|c|}{ GostadeEsporte } & \multirow{2}{*}{ Total } \\
\cline { 2 - 3 } & Sim & Não & \\
\hline $\mathrm{M}$ & 50 & 10 & 60 \\
\hline $\mathrm{F}$ & 30 & 10 & 40 \\
\hline Total & 80 & 20 & 100 \\
\hline
\end{tabular}

a) Qual a probabilidade de que um aluno escolhido seja do gênero masculino e goste de esporte?

b) Qual a probabilidade de que um aluno escolhido seja do gênero masculino ou goste de esporte? 
c) Qual a probabilidade de que um aluno escolhido goste de esporte, sabendo que é do gênero masculino?

Observamos nesta questão, se após as atividades haveria mudança na atitude com relação à negligência das informações.

Esta questão apresentou mudança significativa apenas para o primeiro item, pelo fato dos alunos antes do curso não terem qualquer tipo de treinamento e não saberem calcular a probabilidade, e consequentemente fiando-se na representatividade do "homem gostar mais de esporte do que as mulheres", não levando em consideração os dados para a solução do problema.

Conforme os gráficos da Figura 19, para uma probabilidade esperada de 0,5 de ser do gênero masculino e gostar de esporte, a mediana apontou para este valor, mostrado um comportamento correto no cálculo desta probabilidade.

Na correção da prova, verificamos o cálculo que estava demonstrado nos casos em que estavam corretos. Para os incorretos, os valores foram indicados sem justificativa, e sem qualquer indício de raciocínio, levando à conclusão de um possível chute como resposta.
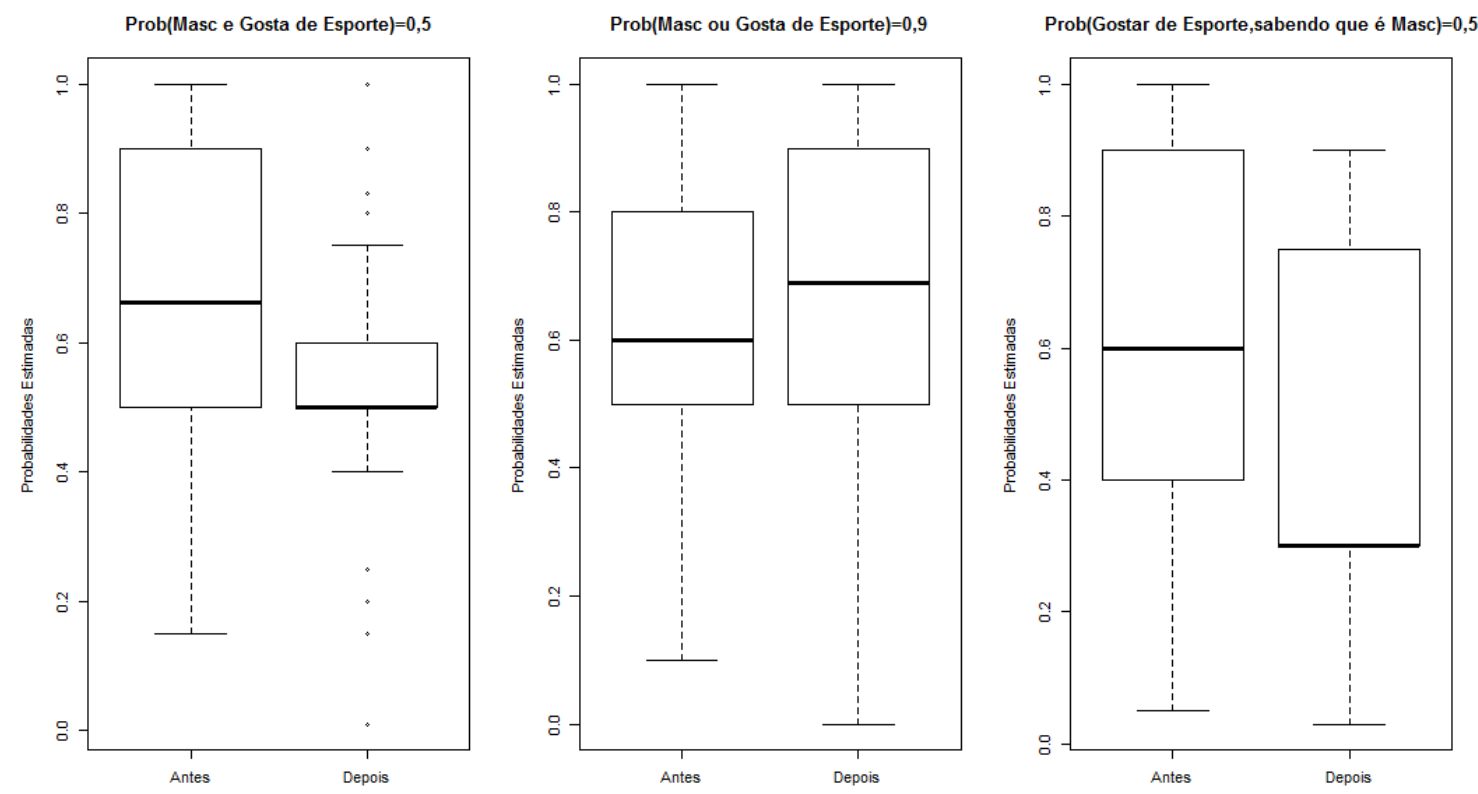

Figura 19: Comparativo para as estimativas das probabilidades dos esportes antes e após as atividades

Já os outros dois itens da questão também não apresentaram justificativas, bem como as estimativas não apresentaram o viés de representatividade, e que na verdade revelaram 
chutes ou cálculos incorretos (conforme observado na correção das provas). Os dois itens tiveram baixos níveis de acerto, com 34\% para o item (b) e 30\% para o item (c) de acordo com os cálculos apresentados para as três turmas.

Os percentuais de acerto para esta questão nos itens a, b e c, serviram de base comparar com a crítica de Gigerenzer(1994): a informação da forma como apresentada via tabela e como frequências fazem as heurísticas (ou falácias) de representatividade diminuírem. Os resultados vêm a seguir.

\section{Quarta Questão:}

Quando Lígia para em um posto de gasolina, a probabilidade de ela pedir para verificar o nível de óleo é de 0,28; a probabilidade de ela pedir para verificar a pressão dos pneus é 0,11 e a probabilidade de ela pedir para verificar ambos, óleo e pneus, é de 0,04. Com base nas informações, calcule:

a) A probabilidade de Lígia pedir para verificar o óleo ou pedir para verificar a pressão dos pneus.

b) A probabilidade de Lígia pedir para verificar a pressão dos pneus, dado que pediu para verificar o óleo.

Verificamos se a mudança na forma de representação da informação dada como frequências como no caso da questão 3, surte efeito com relação à informação passada da forma de probabilidade de evento simples. $\mathrm{O}$ treinamento para este tipo de questão com outro tipo de representação foi dado durante as aulas nos exercícios do livro texto, e colocada na atividade mensal sobre probabilidade da união e condicional.

A comparação assim, foi feita com os itens b e c da questão 3, que foi apresentada na forma de tabela com as frequências, respectivamente a probabilidade da união e a probabilidade condicional. Neste caso estávamos interessados não em testar a efetividade quanto à diminuição ou eliminação da representatividade, e sim, quanto à eficácia da representação da informação, que se configura como a base da crítica de Gigerenzer(1994) ao Programa Heurísticas e Vieses.

Nesta comparação, se nos itens (b) e (c), sob forma de informação por frequência via tabela de dupla entrada de nossa questão 3 do pós teste, os acertos foram de $34 \%$ e $30 \%$ para perguntas com o mesmo conteúdo desta questão, atingindo a totalidade dos 94 alunos frequentes nas três turmas, neste outro formato trouxe um resultado arrasador: nenhum aluno acertou esta questão, em nenhum dos itens. 
Nossas suspeitas acerca da efetividade da linguagem frequentista, citada no trabalho de Gigerenzer como matematicamente equivalentes, mas psicologicamente diferentes foram observadas nestes resultados. No entanto, não podemos corroborar nesta análise a crítica de Gigerenzer, conforme mencionado na falácia da Conjunção (seção 1.5), que a heurística de representatividade é uma "alegada ilusão cognitiva estável”, já que os resultados mostraram o comportamento dos alunos em julgar, mesmo com a informação na forma de frequências, guiados pelo viés de representatividade.

Sobre as conclusões dos resultados de nossa pesquisa e outros pontos de vista faremos uma análise na próxima seção.

\subsection{2 - Comentários dos Resultados}

A sondagem inicial da pesquisa procurou mapear as heurísticas e vieses como modelos mentais utilizados pelos alunos para julgarem possíveis cenários ante a incerteza de um evento.

O levantamento das respostas das questões do pré-teste mostrou que as questões, cujo meio favoreceu uma resposta conjuntural, nem sempre foram compatíveis com os vieses da representatividade e disponibilidade, questões estas como a reincidência de presos no Brasil, sucesso ou fracasso de uma loja, chance de quebra de uma TV após a garantia.

Dentro de nossa realidade, estas questões possuem um contexto em que o aluno possui algum conhecimento, em que o meio lhe é familiar, fazendo com que o comportamento das estimativas tivessem medianas razoáveis de acordo com a resposta esperada (mediana de $0,50)$, indicando qualquer resultado possível mediante informações irrelevantes, levando em conta abstrações e informações que não constavam na questão, mas que serviram para lhes fornecer apoio necessário para um julgamento pelo menos não tão precipitado.

A forma como o grupo de questões que foram familiares aos alunos ajudou a tornar o efeito das heurísticas e vieses, em geral não significativo tem ligação com uma prática descrita por Kahneman (2012), como uma tentativa de disciplinar a intuição, já que as crenças e ideias que vêm à mente são praticamente automáticas. A sugestão envolve dois passos: 
1. Ancore seu julgamento da probabilidade de um resultado numa taxa-base plausível.

2. Questione a diagnosticidade de sua evidência (o quanto ela faz sentido para você).

O primeiro passo é o mais complicado, pois exige um esforço de atenção constante, em que o próprio Kahneman assume não ser otimista quanto ao controle ou eliminação dos vieses, pois segundo ele é uma ação exaustiva. Já o segundo passo, citado acima, que em particular tem ligação com as questões contextuais do cotidiano do aluno, é o que as torna tão importantes, pois foi a ação tomada pelos alunos ao questionar o cenário (no caso escasso e em alguns casos não informativos), gerando outros fatores não considerados no problema, que efetivamente ajudaram a julgar as probabilidades de forma mais conservadora, isto é, de 0,50 para qualquer resultado.

As questões que apresentaram forte viés de representatividade no pré-teste foram testadas em um pós-teste e apresentaram os cenários que passaremos a descrever.

$\mathrm{Na} 1^{\mathrm{a}}$ questão, sobre a profissão mais provável, o resultado do pré-teste mostrou que o viés de representatividade foi fortemente observado, pois os alunos não levaram em conta as profissões mais frequentes na população, deixando-se levar pelos estereótipos que julgaram ser mais representativos para as características citadas no problema. No pós-teste, com as atividades e experiências propostas para as aulas, observamos que houve mudança considerável no cenário das respostas, das profissões de vendedor e físico: as distribuições inverteram as suas tendências, e a profissão de vendedor apresentou probabilidades mais altas no pós-teste (uso da taxa base, já que vendedores são mais frequentes em nossa população). No caso do físico, o que antes fora julgado como muito provável, após as atividades, foi julgado como pouco provável pelos alunos (mediana 0,30). Nas demais profissões não houve mudanças consideráveis, permanecendo praticamente inalteradas as distribuições.

Apesar da inversão no julgamento das profissões de vendedor e físico, observamos pelas justificativas, apenas uma pequena parcela dos alunos considerando as taxas-base da população ( $\mathrm{n}=10)$, após as ações em sala de aula, enquanto que a grande maioria, apesar de ter estimado da mesma forma as probabilidades, mantiveram suas justificativas baseadas nos estereótipos apresentados.

A $2^{\mathrm{a}}$ questão (lançamento de moedas) também apresentou um quadro inalterado para as estimativas de probabilidade. Mesmo após as aulas terem sido direcionadas para uma 
abordagem frequentista da probabilidade, ou a aplicação de experiências no lançamento de moedas com a observação da convergência do valor da probabilidade, e as discussões levantadas durante a aula ou ainda pelos desafios lançados, os alunos se mostraram resistentes quanto ao julgamento da probabilidade de honestidade das moedas, baseados nas sequências curtas que mantiveram como representativas para o lançamento de uma moeda.

$\mathrm{Na} 3^{\mathrm{a}}$. questão aplicada, tabela de dupla entrada esporte x gênero, o baixo número de acertos para os cálculos das probabilidades mostrou um outro aspecto além dos esperados pela pesquisa, como a falta de empenho e esforço para resolução da prova, dado que para o grande grupo dos alunos que não acertaram, não havia qualquer indício de raciocínio ou tentativa de cálculo.

Para a $4^{\mathrm{a}}$. questão, não oferecida no pré-teste, foram fornecidos valores de probabilidades sem representação de tabela. $\mathrm{O}$ resultado foi drástico, pois nenhum aluno acertou as questões, o que corrobora a ideia de Gigerenzer(1994), ao mostrar a grande importância da forma de representação da informação, ou seja, sob a forma de tabelas informando frequências, o resultado foi melhor. Como já dito, esta questão não teve comparação com a fase anterior, e só foi colocada nesta fase à guisa de comparação com a $3^{\mathrm{a}}$ questão.

Nas questões onde foram detectados no pré-teste o viés de representatividade, tanto as mais abstratas como o lançamento de moedas, como das profissões cujos estereótipos tiveram papel substancial nos erros de julgamento, e até mesmo no caso da questão da tabela de dupla entrada (gostar de esporte x gênero) houve diminuição não tão significativa nas violações dos julgamentos em probabilidade. De acordo com a aplicação das atividades, percebemos que são questões que requerem um amadurecimento por parte dos alunos, que devem ser abordadas durante um tempo maior, mostrando a dificuldade de corrigir, em sala de aula, os vieses associados a estes tipos de julgamentos. 


\section{Capítulo 4 - Considerações Finais}

\section{1 - Sobre o Programa Heurísticas e Vieses}

No capítulo 1 mostramos várias definições do termo "Heurística" que referem procedimentos de busca de respostas adequadas, não necessariamente precisas, para situações de incerteza. Segundo Kahneman et al. (1982) elas são econômicas e muitas vezes efetivas embora possam conduzir a erros sistemáticos e previsíveis. Para reduzir os possíveis erros cometidos, é importante ter domínio sobre o uso das heurísticas e a existência de vieses, tornando mais precisos, dessa forma, nossos julgamentos frente à incerteza.

Este trabalho procurou verificar a existência das heurísticas de representatividade e de disponibilidade que, com maior ou menor intensidade, levaram a erros posteriores.

Os pesquisadores Tversky e Kahneman (1983), em um dos seus estudos sobre o efeito da representatividade na probabilidade da conjunção, fizeram um levantamento com 64 estudantes de pós-graduação em ciências sociais de universidades norte-americanas, onde todos possuíam créditos em várias disciplinas de estatística. O resultado foi que $36 \%$ apenas deles cometeram violações. Assim, a educação estatística no estudo dos autores produziu uma maioria $(64 \%)$ em conformidade com as regras de conjunção em probabilidade, mas ainda assim foi observado um alto índice de violações para um grupo educado estatisticamente.

Este resultado indica que mesmo para um grupo que obteve treinamento estatístico, ou em probabilidade, o fenômeno da representatividade não é erradicado, de onde podemos concluir com base neste estudo, que apesar das atividades e aulas propostas e aplicadas, não se pode erradicar por completo as falácias ou heurísticas no julgamento dos alunos, pois conforme a pesquisa de Tversky e Kahneman(1983):

"Pesquisas modernas de categorização de objetos e eventos mostraram que as informações são comumente armazenadas e processadas por modelos mentais, tais como protótipos ou esquemas. É natural que a estimação da probabilidade de um evento seja estimada pelo grau com que o evento seja representativo de um apropriado modelo mental." 
Com respeito à disponibilidade, Kahneman et al (1982) acreditam que ela fornece um mecanismo pelo qual ocorrências de extrema utilidade, por exemplo ganhar na loteria, possam parecer mais prováveis do que realmente são.

Esse Programa Heurísticas e Vieses recebeu críticas e vimos na seção 1.5 que o psicólogo alemão Gerd Gigerenzer(1994) é considerado o crítico mais persistente a ele.

Gigerenzer insiste que a principal falha do programa é reinvindicar as falhas de raciocínio. Ele aponta a importância da representação da informação, pois as pessoas se confundem ao receber a informação sob forma de probabilidades de eventos simples (na forma 0.40 ou 0.15 por exemplo) preferindo a representação sob a forma de frequências (na forma "uma entre oito", por exemplo). Gigerenzer considera um absurdo dizer, por exemplo, que o Sr. X, agora com 40 anos de idade por exemplo, tem a probabilidade de 0.011 de morrer no próximo ano, pois esta probabilidade está ligada a uma classe, mas não a uma pessoa em particular, daí a conclusão que as alegadas heurísticas não são um erro de raciocínio em probabilidade, pois a teoria é sobre frequências, e não se aplica ao caso particular.

Ainda em seu artigo, Gigerenzer(1994) faz testes utilizando as mesmas questões pesquisadas por Tversky e Kahneman mudando o formato das questões para a forma frequentista, mostrando por evidências que a queda é drástica, mas que também não as elimina. Em suma, para Gigerenzer, o bom funcionamento de um algoritmo mental depende da maneira como a informação é apresentada, e não aceita a tese de que o Programa Heuristicas e Vieses induz, a de que "nossa mente não está preparada para pensar estatisticamente", pois isto remete ao perigoso caminho de se deduzir a irracionalidade do ser humano.

Especificamente, se a informação é codificada como uma amostragem de frequências, o que Gigerenzer intitula como "amostragem natural", a nossa mente precisa monitorar somente dois tipos de informação: as frequiências dos eventos de interesse, e não é necessária atenção às taxas base, ou descrições comuns aos vieses de representatividade. Cita ainda experimentos que concluem que as frequências são um dos poucos tipos de informação monitorada automaticamente.

A propósito das críticas ao Programa Heurísticas e Vieses, Kahneman(2012) em sua obra "Rápido e Devagar, duas formas de pensar", comenta que a intenção, desde o início de sua criação com seu amigo Amos Tversky, fora apenas a de contestar a racionalidade como um dogma. A forma como são atualmente encaradas as heurísticas e vieses evoluiu muito desde o início das pesquisas. Hoje, Kahneman descreve a mente provida com dois hipotéticos 
sistemas cognitivos: um rápido, intuitivo e automático, enquanto que o outro sistema opera lentamente, é analítico e requer esforço e atenção. Esta configuração, para ele, explica o que Gigerenzer intitulava como sugestão à irracionalidade, pois as heurísticas e vieses são fruto das ideias e sugestões do sistema automático, mesmo monitorado pelo sistema analítico.

Uma vez que ao longo da vida fazemos muitos julgamentos, convivemos com o conflito entre o conceito intuitivo de probabilidade e a estrutura lógica desse mesmo conceito. De um lado, não é razoável esperar que sejam abandonadas as heurísticas de avaliação de incerteza, pois disso depende a construção de nosso conhecimento de mundo. Por outro lado, não podemos negligenciar as leis probabilísticas, pois elas capturam realidades também deste mundo. O problema (segundo Kahneman et al. , 1982) se resume em conservar o que for útil e válido em um julgamento intuitivo, enquanto corrigimos erros e vieses aos quais ele estiver vulnerável.

\section{2 - Sobre a experiência com Educação Estatística}

Como a mente funciona ou quais os mecanismos que levam a um raciocínio eficiente diante da informação? Estas questões ainda estão em aberto e são referência para toda a corrente de pesquisa que é o Programa Heurísticas e Vieses, bem como a pesquisa em psicologia cognitiva de Gerd Gigerenzer, para citar algumas correntes. Criar formas de monitoramento do sistema automático, talvez seja a chave do enigma de eliminação ou diminuição e controle das heurísticas e vieses. E este foi o nosso intuito com o estudo: o de utilizar as ferramentas que apontassem os melhores mecanismos de abordagem para o ensino de probabilidade e estatística, para erradicação dos vieses.

É inegável a contribuição no campo de ensino, de saber como as intuições são formadas, como os julgamentos ocorrem, tão necessários diante de disciplinas que utilizam processos lógicos como a estatística e probabilidade; e se a controvérsia levantada por Gigerenzer tem por um lado seus argumentos em defesa do homem racional, o Programa Heuristicas e Vieses procura cada vez mais elucidar as intrincadas veredas que nosso sistema cognitivo, analítico e intuitivo. Ambas as correntes estão em busca da solução de problemas de julgamento. 
Erros de raciocínio também foram observados em grandes centros de pesquisa mundiais, e inclusive, o próprio Kahneman cita que quando professor de estatística na década de 1960 cometia os mesmos erros que ele tenta erradicar em seus alunos (Kahneman, 2012).

O ensino de estatística e probabilidade são fundamentais na formação do aluno, de modo geral como tomador de decisões, seja no campo profissional ou em sua vida particular. Ao se deparar com cenários de risco, com informações escassas que levam à construção de estórias coerentes, geralmente incorretas, o aluno, de posse de um treinamento, poderá agir de forma mais consistente com a realidade.

Em nosso estudo fizemos um levantamento prévio para sondar os apontamentos indicados por nosso referencial, que indicasse um caminho ou abordagem que se mostrassem eficazes na diminuição de erros de raciocínio em probabilidade e estatística. As evidências mostraram a existência de vieses no julgamento por parte dos alunos - aplicamos as atividades com o intuito de evidenciá-los, e por fim criar formas de monitorá-los para que pudessem ser evitados.

A eficácia de tal abordagem surtiu um efeito parcial para alguns tipos de heurísticas, mas notamos também que as dificuldades encontradas em sala de aula precisam de uma atenção primordial, tanto para a abordagem que propomos com o trabalho, como para questões estruturais (seção 2.4.1). Nossa tentativa foi a de criar o ambiente mais propício possível para o aprendizado em probabilidade e estatística, apesar da existência de fatores que fugiam ao controle do estudo: a estrutura do colégio, defasagem com relação ao conteúdo fundamental de matemática que atestamos durante as aulas e falta de professores, e por fim todos os problemas pelos quais passa a educação básica do Estado de São Paulo.

Os fatores externos à pesquisa talvez explicassem apenas o fato observado no rendimento da prova bimestral, como o fraco rendimento das últimas questões do pós-teste, pois a eliminação total da ocorrência de erros em julgamentos e/ou falhas de raciocínio que não conseguimos em nosso trabalho, também não foi verificada completamente nos relatos das pesquisas tanto do Programa Heurísticas e Vieses, como de Gigerenzer, que relatam problemas encontrados mesmo com pessoas treinadas em estatística e probabilidade.

Kahneman(2012) sugere que os erros de previsão são inevitáveis porque o mundo é imprevisível. No entanto obtivemos evidências de que conhecer os mecanismos ligados ao raciocínio é fundamental para tornar a aula efetiva e essencial em sua busca para um entendimento da disciplina (probabilidade e estatística) e erradicação, pelo menos em parte, de vieses. 
Uma sugestão seria começar já no fundamental II uma discussão de problemas da natureza dos que foram vistos neste trabalho de forma a ir construindo uma referência deste tipo de raciocínio com os alunos. Simulação também é recomendável, o que pode ajudar a diminuir a resistência dos alunos em aceitar alguns argumentos probabilísticos.

Fazer com que o ensino básico de estatística e probabilidade não se restrinja aos aspectos algoritmizados da matemática e que tenha um sentido cada vez mais efetivo para o aluno, e fazer com que os conceitos tenham um lugar essencial em suas vidas, para que as decisões sejam conscientes, devem ser o objetivo a ser perseguido por todos aqueles que querem participar da formação de um cidadão pleno em nosso país. 


\section{Referências Bibliográficas}

Abrantes, P. (1995): Avaliação e Educação Matemática. Série Reflexões em Educação Matemática: MEM/USU-GEPEM. Lisboa, 88p.

Batanero, C; Godino,J.D.; Vallecillos,A; Green,D.R.; Holmes,P. (1994): Errors and difficulties in understanding elementary statistical concepts. International Journal of Mathematics Education in Science and Technology, 25(4), 527-547.

Batanero, C.; Godino, J.D; Roa,R. (2004): Training Teachers to Teach Probability. Journal of Statistics Education Vol.12, Number 1.

Batanero, C.; Burrill,G. ; Reading, G.(eds.) (2011), Teaching Statistics in School Mathematics - Challenges for Teaching and Teacher Education: A Joint ICMI/IASE Study, Springer Science+Business Media B. V. Cap.10 - Fundamental Statistical Ideas in the school Curriculum and in Training Teachers.

Brousseau, G. (1983): Les obstacles épistémologiques et les problèmes em mathématiques. Recherches en Didactique des Mathématiques, 4 (2), 164-198.

Bussab, W.O.; Morettin, P. A. (2002): Estatística Básica - 5. ed. - São Paulo. Saraiva.

Cordani, L. K. (2012), Estatística para todos: atividades para sala de aula. $1^{\mathrm{a}}$ Ed. São Paulo: CAEM/IME-USP, 60p.

Crawley, M.J. (2007): The R Book. John Wiley \& Sons Ltd. Chichester, England.

Currículo do Estado de São Paulo (2011): Matemática e suas tecnologias. Secretaria da Educação; coordenação geral, Maria Inês Fini; coordenação de área, Nílson José Machado.

Fiorentini, D.; Lorenzato,S. (2006): Investigação em Educação Matemática: Percursos teóricos e metodológicos. Autores Associados: Campinas. 226 pg.

Franklin, C. (2012): Gaise College Report. American Statistical Association.

Gelman, A.; Glickman, M. (2000): Some Class-Participations for Introductory Probability and Statistics. Journal of educational and Behavioral Statistics. V.25(1).

Gigerenzer, G. (1994): Why the distinction between single-event probabilities and frequencies is important for psychology (and vice versa). G.Wright \& P.Ayton (Eds.).

Giovani, J.R.; Bonjorno, J.R.; Giovani Jr., J.r. (2002): Matemática Fundamental Uma Nova abordagem: Ensino Médio Volume Único.São Paulo - FTD.

Giovani, J.R.; Bonjorno,J.R.; Giovani Jr.,J.R. (2011): Matemática Fundamental Uma Nova abordagem: Ensino Médio Volume Único.2.Ed. São Paulo - FTD. 
Giovani, J. R.; Castrucci, B.; Giovani Jr. (2012): Coleção A Conquista da Matemática, $6^{o}, 7^{\circ}, 8^{o}$ e $9^{o}$ anos. - Ed. Renovada - São Paulo: FTD.

Gould, S. J. (1992). Bully for brontosaurus. Further reflections in natural history.Penguin Books.

Iezzi, G.;Hazzan, S.;Degenszajn, D. M. (2004): Fundamentos de matemática elementar,V. 11: matemática comercial, matemática financeira, estatística descritiva. $1^{\mathrm{a}}$ Ed. São Paulo: Atual. Pag 154.

Kahneman, D.; Slovic, P.; Tversky, A.; (1982): Judgment Under Uncertainty: heuristics and biases. Cambridge University Press. Cap.34: On the study of statistical intuitions.

Kahneman, D. (2012): Rápido e Devagar, duas formas de pensar; tradução Cássio de Arantes Leite. - Rio de Janeiro: Objetiva.

Mori, I.; Onaga, D. S. (2000): Matemática, ideias e desafios, $8^{a}$ série. São Paulo: Saraiva.

Polya, G. (1978): A Arte de Resolver Problemas. Rio de Janeiro: Interciência.

Severino, A. J. (2007) Metodologia do trabalho científico. 23 ed. rev. e atual. São Paulo: Cortez.

Smole, K.; Diniz, M.I. (2005): Matemática Ensino Médio - V.2. 5. Ed. São Paulo: Saraiva.

Souza, J. R.(2012): Vontade de Saber Matemática. $6^{\circ}$ ano - 2 ed - São Paulo: FTD.

Triola, M. F.(2008) Introdução à estatística. 10 ed. - Rio de Janeiro: LTC.

Tversky, A; Kahneman, D. (1974): Judgment Under Uncertainty, Heuristics and Biases: Biases in judgments reveal some heuristics of thinking under uncertainty. Science, Vol. 185, September.

Tversky, A; Kahneman, D. (1983): Extensional Versus Intuitive Reasoning: The Conjunction Fallacy in Probability Judgment. Psychological Review, Vol. 90, Number 4. American Psychological Association, Inc.

Vasconcelos, E. M. (2002): Complexidade e pesquisa interdisciplinar: epistemologia e metodologia operativa. Petrópolis, RJ: Vozes. 